\title{
Efficacy of Energy Efficiency and Thermal Comfort Related Retrofit for Existing New Zealand Houses
}

\author{
Yanguang Zhang \\ Victoria University of Wellington
}

2010

A thesis submitted to School of Architecture, Victoria University of

Wellington in fulfilment of the requirements for the degree of Masters of Building Science. 


\section{Abstract}

Many New Zealand studies have argued that house energy retrofit produces limited benefits, but the issue of how existing house retrofitting can lead to better energy performance and comfort improvement is little explored.

The aim of this thesis was to examine the influence of house retrofit on energy efficiency and thermal comfort, using house model simulation and calculation. This study gives a holistic house retrofit approach in thermal comfort improvement and energy conservation. Three house retrofit categories were defined by household energy breakdown: Space Heating Retrofit, Hot Water System Retrofit and Appliances Retrofit.

This study started with an investigation of New Zealand existing house stock. A typical house model was defined by the summarized common physical characteristics. This house model was used for retrofit testing. For the building space heating retrofit study, a series of thermal simulations was completed with different retrofit options. Thermal simulation results were compared both in thermal comfort and space heating energy requirement. It was discovered that the optimum level full insulation retrofit significantly reduced space heating energy requirement and also improved thermal comfort.

Retrofit solutions for water heating, lighting and appliances were compared by cost and energy saving. Cost effectiveness cross comparison for all of the retrofit solutions was carried out. Retrofitting for space heating system and hot water system can be considered for long term cost effectiveness. Appliances and lighting retrofit have a higher efficacy than other retrofit options in terms of energy saving and cost benefit cycle.

These findings are used to provide suggestions for retrofitting of existing houses.

Keywords: House Retrofit, Insulation, Energy Efficiency, Thermal Comfort. 


\section{Acknowledgements}

I would like to acknowledge the support and advice of Primary supervisor

Professor Robert Vale (School of Architecture, Victoria University of Wellington).

This work would not have been possible without the support of his supervision and guidance.

Also, I would like to thank Professor Brenda Vale (School of Architecture, Victoria University of Wellington), who was always available and contributed valuable feedback and advice.

I am very thankful to my New Zealand home stay family, Mr. Royce Creamer and his dear mother (Grandma) in her 90's and his sister (Jeanette), for being treated and accepted as a family member, and the years' very kind care, understanding and support.

I would like to make a special acknowledgment to Yanna Qi (my wife to be in one month time) whose love and support made this Masters thesis possible.

I am very much grateful to my fellow postgraduate students of the School of Architecture, Victoria University of Wellington, for their kind assistance, advice and knowledge. 


\section{Preface}

This thesis was submitted as part of the requirements for the degree of Master

of Building Science at the School of Architecture, Victoria University of Wellington.

Author:

Yanguang Zhang

School of Architecture

Victoria University of Wellington

Email: ygoocn@hotmail.com

Primary Supervisor:

Professor Robert Vale

Professorial Research Fellow

School of Architecture

Victoria University of Wellington

Email: robert.vale@vuw.ac.nz 


\section{Table of Contents}

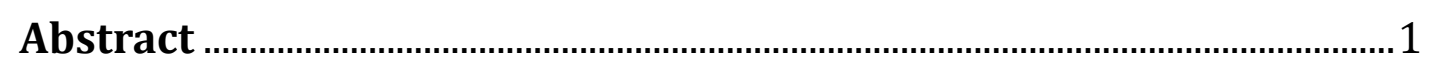

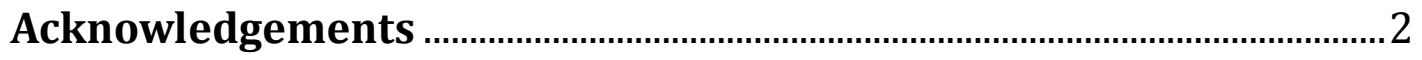

Preface

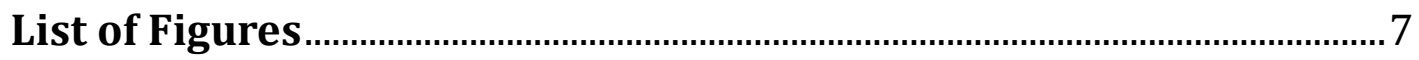

List of Tables …….........................................................................................

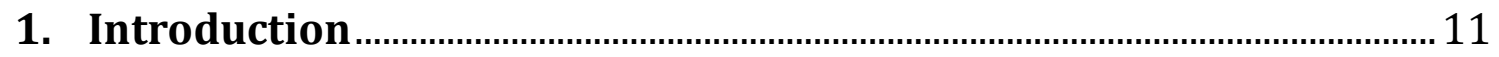

2. Research Context and Objectives................................................................. 14

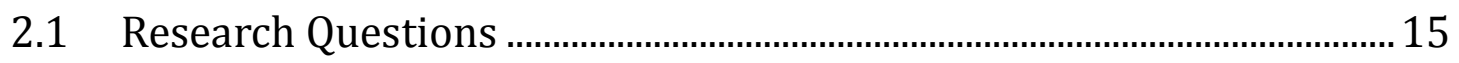

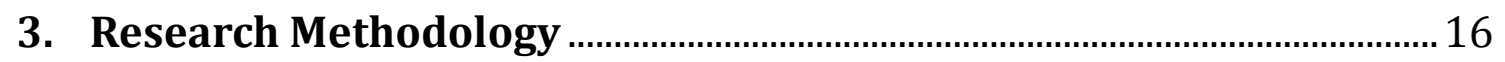

4. Structure of This Thesis …………………………………………………….... 19

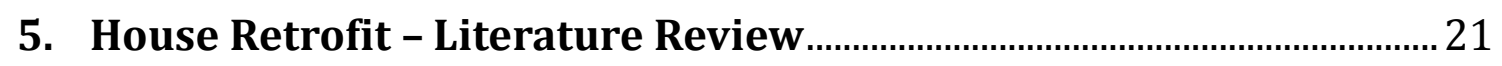

5.1 The need for existing houses retrofit …………………………………..... 22

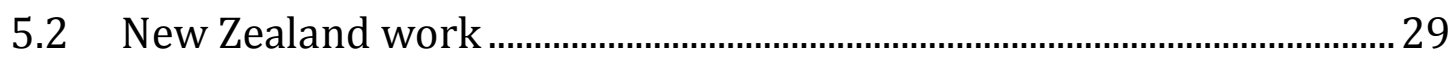

5.3 Occupants' behaviour effect in house retrofit--Rebound Effect...........34

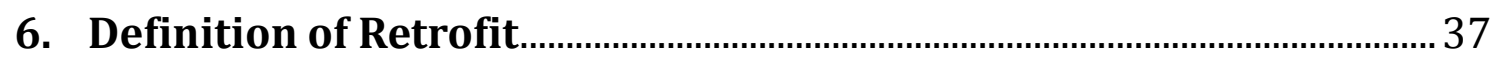

6.1 Retrofit category breakdown .................................................................. 40

7. Investigation of New Zealand House Stock ……………………………..... 42

7.1 House stock, type and size....................................................................... 42

7.2 House construction types investigation ..................................................... 45

7.3 Typical building element construction of majority houses ..................... 47

7.4 House demolition and rebuild ....................................................................... 48

7.5 Building regulation change ……………………………………………........ 49

7.6 New Zealand house envelope retrofit strategy ……………………….....51

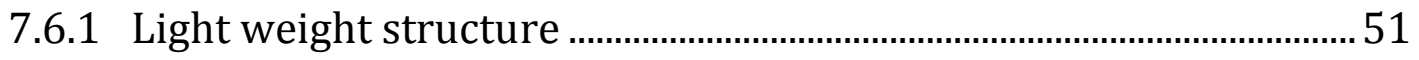

7.6.2 Insulation level ......................................................................................... 52

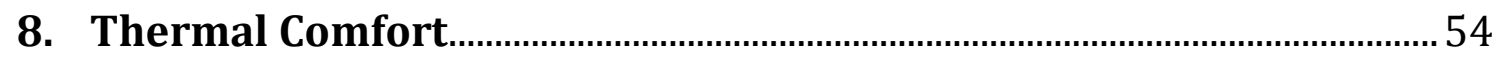


8.1 Variables affecting thermal comfort ………………………………....... 54

8.2 Importance of MRT (Mean Radiant Temperature) …………………….....56

8.3 Thermal assessment method .......................................................................... 57

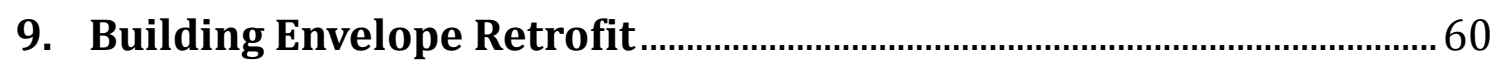

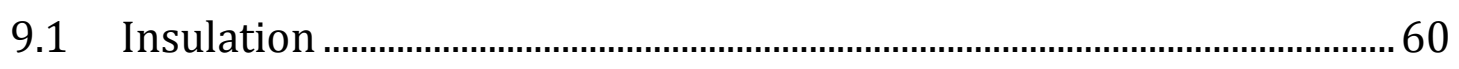

9.1.1 Roof and ceiling ............................................................................................ 63

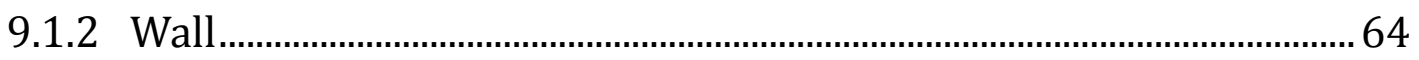

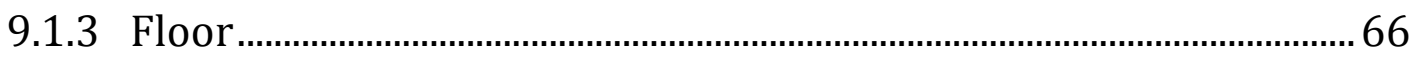

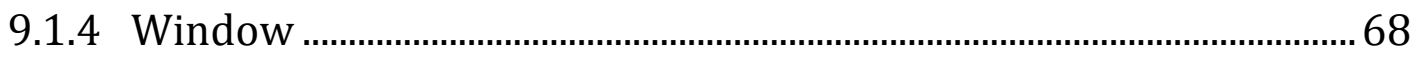

9.2 Ventilation and air infiltration ................................................................... 70

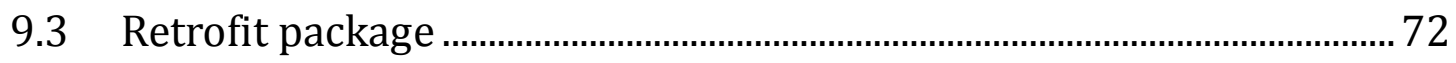

9.3.1 Government house retrofit program ………………………………...... 73

10. Thermal Simulation of Building Envelope Retrofit ................................... 74

10.1 Base building model ................................................................................... 74

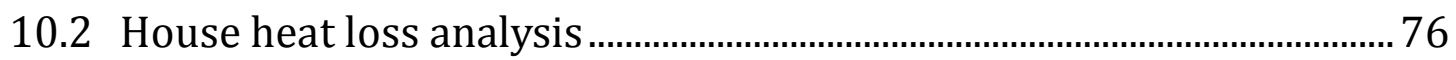

10.2.1 House Model heat Loss Calculation .........................................................

10.3 Detailed house model thermal simulation ....................................................... 83

10.3.1 Simulation tool, EnergyPlus ………………………………………...... 83

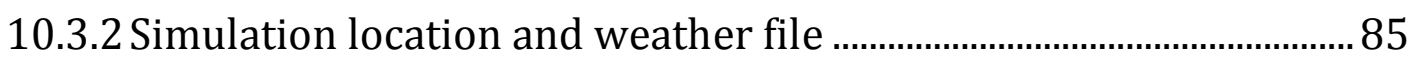

10.3.3 Base building model energy use............................................................. 85

10.3.4 Modelling assumptions ............................................................................ 86

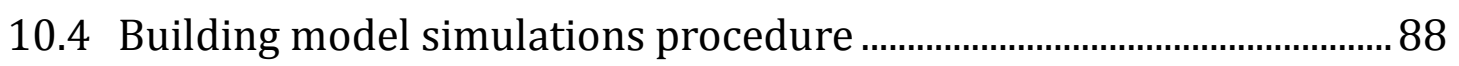

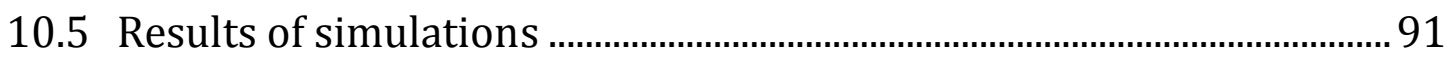

10.5.1 Space heating energy requirement result analysis ............................ 91

10.5.2 Thermal comfort assessment ................................................................ 96

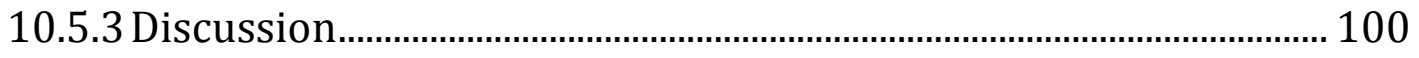

10.6 Cost effectiveness analysis ...................................................................... 101

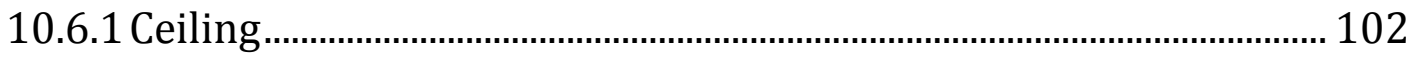




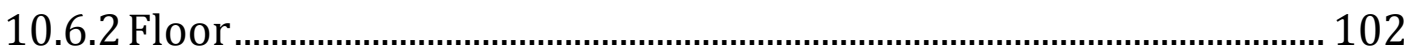

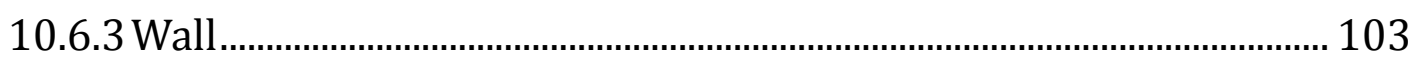

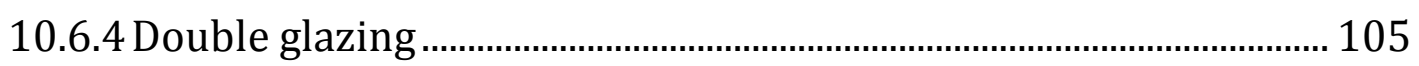

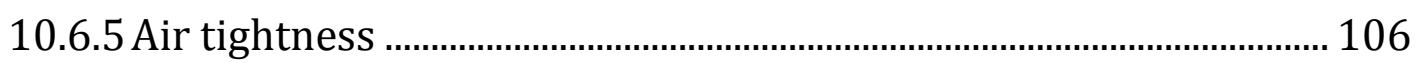

11. Space Heating Equipment Retrofit ....................................................... 109

11.1 Features of New Zealand house heating ……………………………..... 111

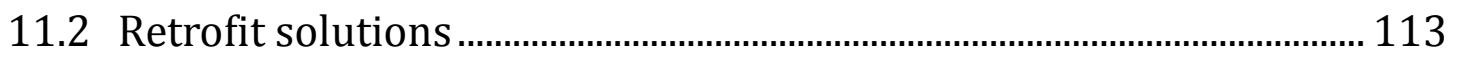

11.3 Heating system selection ............................................................................. 114

12. Hot Water Heating System Retrofit ……………………………………... 116

12.1 Features of New Zealand hot water heating .......................................... 116

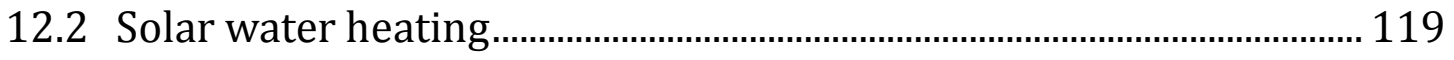

13. Appliances and Lighting Retrofit............................................................. 122

13.1 Category break down.............................................................................. 122

13.2 Refrigeration.......................................................................................... 123

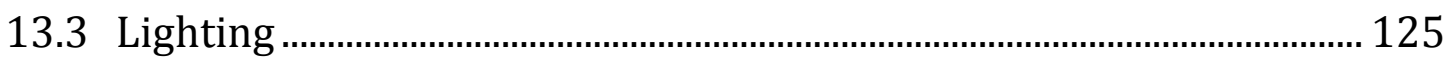

13.4 Range and other appliances.................................................................. 127

13.5 Home appliances new trend ........................................................................ 129

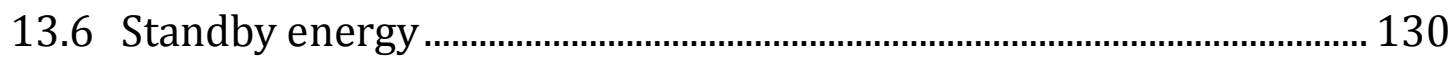

13.7 Appliances retrofit recommendations ………………………..................... 132

14. Findings and Results............................................................................. 133

14.1 Overall comparison of the three retrofit categories ............................ 133

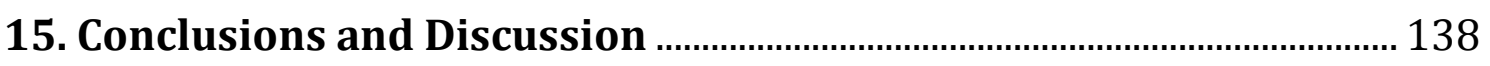

16. Future Research........................................................................................... 144

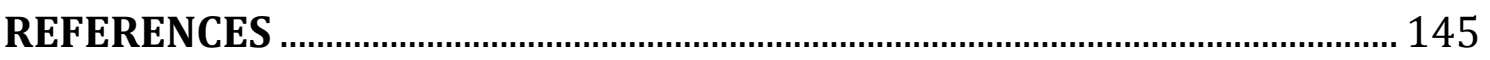

APPENDIX A: New Zealand Climate Zone...…………………………………... 157

APPENDIX B: The National Modal House Plan.................................................. 158

APPENDIX C: House Model Simulation Results ............................................... 160 


\section{List of Figures}

Figure 1: Research Methodology Flowchart .......................................................................... 16

Figure 2 Residential Electricity Price, 1974-2008........................................................... 26

Figure 3: New Zealand Household Energy Breakdown by Average End Use .............. 40

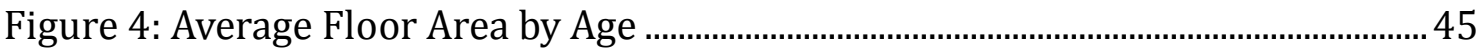

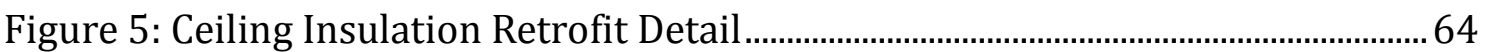

Figure 6: Proposed Underfloor Insulation Retrofit Detail...............................................67

Figure 7: The National Modal House 3d Perspective.................................................................. 74

Figure 8: Thermal Simulation Zones Diagram .................................................................. 75

Figure 9: Wellington Average Household Energy End Use .................................................. 86

Figure 10: Annual and Winter Space Heating Energy Requirement.............................. 92

Figure 11: Building Code Level Elementary Insulation Retrofit Annual Space Heating Energy. 93

Figure 12: Optimum Level Insulation Retrofit Annual Space Heating Energy...........93

Figure 13: Building Code Level Combined Insulation Retrofit Models Annual Space

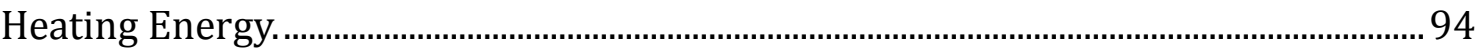

Figure 14: Optimum Level Combined Insulation Retrofit Models Annual Space

Heating Energy. 94

Figure 15: Living Room Winter Period Average MAT and MRT 97

Figure 16: Winter Period, Living Room Mat and MRT Range Band. 99

Figure 17: Retrofit Element Cost 106

Figure 18: Retrofit Combination Cost. 107

Figure 19: Annual Heating Energy Saving and Retrofit Cost 107

Figure 20: Space Heating Energy by Fuel. 
Figure 21: Heating System Fuel Type and Running Price.

Figure 22: Break Down of Hotwater Fuel Types

Figure 23: The Changing Home Environment.

Figure 24: New Zealand Climate Zones.

Figure 25: The National Modal House Floor Plan 158

Figure 26: The National Modal House Elevation. 159

Figure 27: Building Code Level Insulation, Annual Heating Energy, Intermittent Heating Schedule 160

Figure 28: Building Code Level Insulation, Winter Heating Energy, Intermittent Heating Schedule 160

Figure 29: Building Code Level Insulation, Annual Heating Energy, Intermittent Heating Schedule 160

Figure 30: Building Code Level Insulation, Winter Heating Energy, Intermittent Heating Schedule 160

Figure 31: Optimum Level Insulation, Annual Heating Energy, Intermittent Heating Schedule. 161

Figure 32: Optimum Level Insulation, Winter Heating Energy, Intermittent Heating Schedule. 161

Figure 33: Optimum Level Insulation, Annual Heating Energy, Intermittent Heating Schedule. 161

Figure 34: Optimum Level Insulation Model Winter Heating Energy, Intermittent Heating Schedule. 161

Figure 35: Living Room, Annual Average MAT and MRT without Heating.. 162 


\section{List of Tables}

Table 1: Retrofit Category Details. ..................................................................................... 41

Table 2: Dwellings Type and Number Variation By Recent Years...................................... 43

Table 3: Frequency of Occurrence of Common Specifications. .......................................... 46

Table 4: HEEP House Samples Structural Character Breakdown.................................... 47

Table 5: Building Code Requirement of Building Elements R-values ............................49

Table 6: 2008 Building Code Upgrading Before/After Construction Cost and

Insulation Investment Return Period................................................................. 51

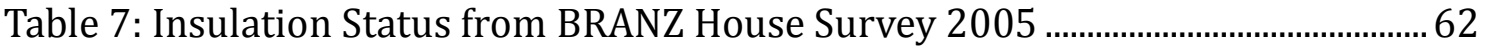

Table 8: Insulation and Construction Type of Pre-1979 Dwellings................................. 63

Table 9: Base Level Average Infiltration Rates.................................................................. 72

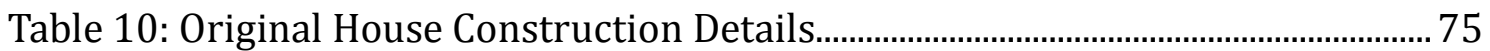

Table 11: Proposed Optimum Retrofit Package Details ........................................................ 76

Table 12: House Heat Loss Breakdown by Different Elements......................................... 77

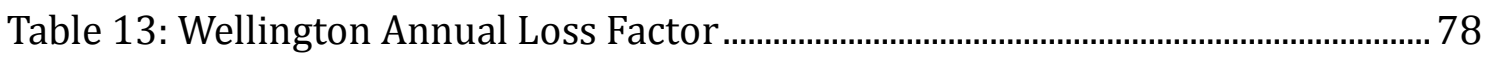

Table 14: Different Scenario R-values ...................................................................................... 79

Table 15: The Modal House Heat Loss Calculation .................................................................. 80

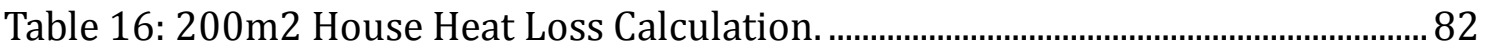

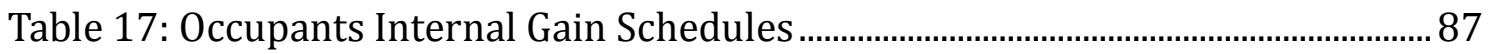

Table 18: Space Heating Schedule and Temperature Set Point .......................................... 87

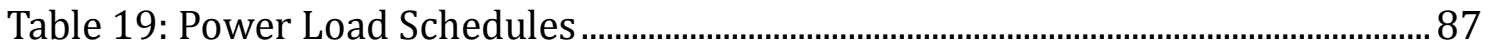

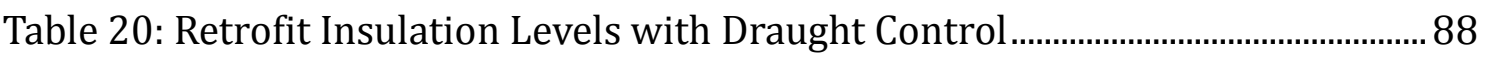

Table 21: Building Code Level Retrofit Model Details..................................................... 89

Table 22: Optimum Level Retrofit Model Details. ................................................................... 90 
Table 23: Simulation Schedule and Analysis Data Type 91

Table 24: Heating Energy Comparison of Double Glazing Retrofit 95

Table 25: HEEP Monitored Winter Living Room Temperatures. 98

Table 26: Ceiling Retrofit Cost 102

Table 27: Floor Insulation Retrofit Cost... 103

Table 28: Wall Insulation Retrofit Cost. 104

Table 29: Window Retrofit Cost 105

Table 30: Draught Control Cost 106

Table 31: Heating Fuel Types and Proportion 111

Table 32: Heating Systems Comparison. 114

Table 33: Tap Hot Water Temperatures and Cylinder Thermostat Temperatures of HEEP Monitored Houses. 118

Table 34: Average Appliance Electricity Consumption Per Household. 123

Table 35: Refrigeration Retrofit Solutions Calculation 124

Table 36: Lighting Retrofit Cost Calculation 127

Table 37: House Retrofit Cost Effectiveness Cross Comparison. 134

Table 38: Retrofit Investment and Saving Calculation 136 


\section{Introduction}

Over recent years the renovation impulse has changed. Home renovation was once a DIY activity with the work being almost as decoration. Yet people's attitudes have changed and, with more awareness of sustainability, many of the people undertaking retrofitting work are opting to improve energy efficiency and thermal comfort. There is now a growing interest in the value of the physical condition of New Zealand's houses, due to the stronger awareness of health and energy consumption impacts.

In New Zealand, numerous research works have demonstrated that houses are cold, damp and inadequately heated. Home retrofit has been seen as an effective way to improve the quality of people's lifestyle and increase the value of what is usually the largest single investment for house owners. There is also a growing acceptance that we all have a part to play in preserving an increasingly fragile environment. Such choices are now seen to be positive steps towards attaining good, thoughtful strategies - as good for our houses as they are for the planet.

Home retrofit is essentially about choices; about determining solutions, materials and products that enhance the performance of the existing homes without adversely affecting the environment. Most of all, home retrofit should be about assured efficacy and the value of achieving the optimum both in thermal comfort and energy saving.

The purpose of this study is to explore the margin for house retrofit and make the optimal benefits of both indoor comfort and energy saving.

The Ministry of Economic Development's report (Ministry of Economic Development, 2009, p.12 and 104), based on 2005 data, shows that the energy 
consumption of the residential sector represents $12.2 \%$ of the total energy and $34.2 \%$ of the electricity energy input to New Zealand. Of the energy used by an average household (Isaacs et al, 2006; p.19) space heating accounts for $34 \%$ and water heating for $29 \%$, with lighting, cooking, and energy for appliances making up the remaining $37 \%$. Therefore it is clear that if reductions are to be made in the energy consumption of the domestic space heating, water heating and appliances are equally important.

From the point of building life cycle energy, Mithraratne et al. pointed out that compared with building embodied energy, operating energy is the largest component of life cycle energy and reduction in operating energy should be the priority. For house retrofit, insulation is generally the main solution to reducing operating energy and should be taken as a priority (Mithraratne et al, 2007, p.209).

For building fabric retrofit, the rule of thumb is how heat loss can be diminished in order to increase energy efficiency. There is important interaction between building element insulation level and heating energy, and trade-off is possible between the expense of these two items; for example, while the installation of insulation and double glazing may lead to a higher initial cost it may also require less space heating energy demand and therefore lead to lower power cost.

Building regulation has an important role in thermal comfort and energy efficiency improvement. In New Zealand, the first statutory regulations were introduced for insulation in houses in 1978. Research by BRANZ found that winter evening living room temperatures of post-1978 houses were $1^{\circ} \mathrm{C}$ warmer than pre-1978 ones (Isaacs et al, 2006). This is believed to be the result of higher level of insulation and better controlled air tightness. 
At present, some research has been carried out in the area of existing houses' thermal performance and household energy efficiency based on the New Zealand background. However, there is a need for holistic analysis for all energy and thermal comfort related retrofit options.

This thesis attempts to give a cross comparison through different house retrofit options in terms of thermal performance and energy requirement. With the target of thermal comfort and energy efficiency, in this study, three retrofit categories are defined as: building fabric retrofit, water heating retrofit and appliances retrofit. By investigation of New Zealand house stock and analysis of common house characteristics, a typical house model is defined for retrofit options tests. The results of comparison of energy savings from building fabric retrofits and other household energy related retrofit are given.

The results of the simulations found out that comfortable indoor temperature can be reached with low level space heating energy requirement, after an overall building fabric retrofit. With regard to water heating retrofit and appliances retrofit, energy consumption can be reduced, if some of the appliances and light bulbs are upgraded with high energy efficiency ones. Also, it is found that greater house performance can be expected, if government could subsidise full insulation retrofit cost. Occupants' operation patterns and behaviour choices can play as big a role for reduction of energy use, after the house retrofit work.

This study demonstrated the value of the combined home retrofitting approach, which allows householders to make a lesser impact on the environment and live in more comfort and greater health than is currently the situation. The result will provide a logical house retrofit pathway based on desired outcomes. 


\section{Research Context and Objectives}

In New Zealand, a pilot insulation retrofit study was carried out by Cunningham and his BRANZ colleagues. One timber framed house, built in 1929, was used for experimentation. This house was retrofitted in different stages, ceiling and floor insulation first, and then wall insulation. Three years' energy use and indoor temperature were monitored. It was found that applying insulation increased indoor temperature by around $1.40^{\circ} \mathrm{C}$ in winter, with a reduction in energy use of 300-400 KWh per year (Cunningham et al, 2001, p.1-3). BRANZ also completed a retrofit study on some pensioner flats in Wellington and found little difference in temperatures and energy use between before and after retrofit (Isaacs et al, 2006, p.73).

At present, the biggest and most intensively observed retrofit project was conducted by the Department of Physics, University of Otago. A totally of 111 state houses were insulation retrofitted and monitored in the southern region of New Zealand. The study found a small reduction in energy consumption of $5 \%$ $9 \%$ and $0.6^{\circ} \mathrm{C}$ temperature increase after roof and underfloor insulation retrofit (Lloyd and Callau, 2006, p.A). This study did not achieve any very significant improvements in energy saving and indoor comfort. Reasons of this result may include:

- Some houses already had some ceiling insulation.

- Also, the new insulation was installed at a basic level only.

- Only ceiling and floor were insulated.

Overall, most previous studies in house insulation retrofit found no or little energy saving and temperature increase.

All of the previous research has shown that basic level insulation retrofit could not be sufficient to provide comfortable indoor environment and make 
remarkable energy savings.

Also, the efficacy of house retrofit is questionable for thermal comfort and energy saving.

In such a context, the development of high efficacy house retrofit is really desirable. The whole package of retrofit solutions for both building envelope and household energy using appliances is required. To meet this demand, this research was set up with the following objectives:

1. Review the existing New Zealand house stocks in terms of house physical character, feasibility of retrofit, household energy use.

2. Examine the efficacy of different retrofit solutions regarding the aspects of thermal comfort or heating energy requirement.

3. Analyse and compare the cost benefit of different retrofit measures.

4. Provide recommendations of retrofit strategies which can be used to minimize household energy use and improve indoor comfort.

\subsection{Research Questions}

This study will address the following questions:
A. Why is the current New Zealand house insulation retrofit efficacy low?
B. What is the possible optimal efficacy of building element insulation retrofit?
C. How is thermal comfort traded off by energy saving after retrofit?
D. How to improve the efficacy of hot water heating system retrofit?
E. How to improve the efficacy of appliances and lighting retrofit?
F. What is the cost effectiveness comparison between space heating retrofit, hot water heating retrofit, and appliances retrofit? 


\section{Research Methodology}

This section will present an overview of the methodology used to examine the efficacy of New Zealand housing retrofit, which is aiming to improve energy efficiency and thermal comfort. In order to reach this goal, the research is carried out in the following stages. The flowchart below illustrates the devised methodology and the whole research was completed in such a process.

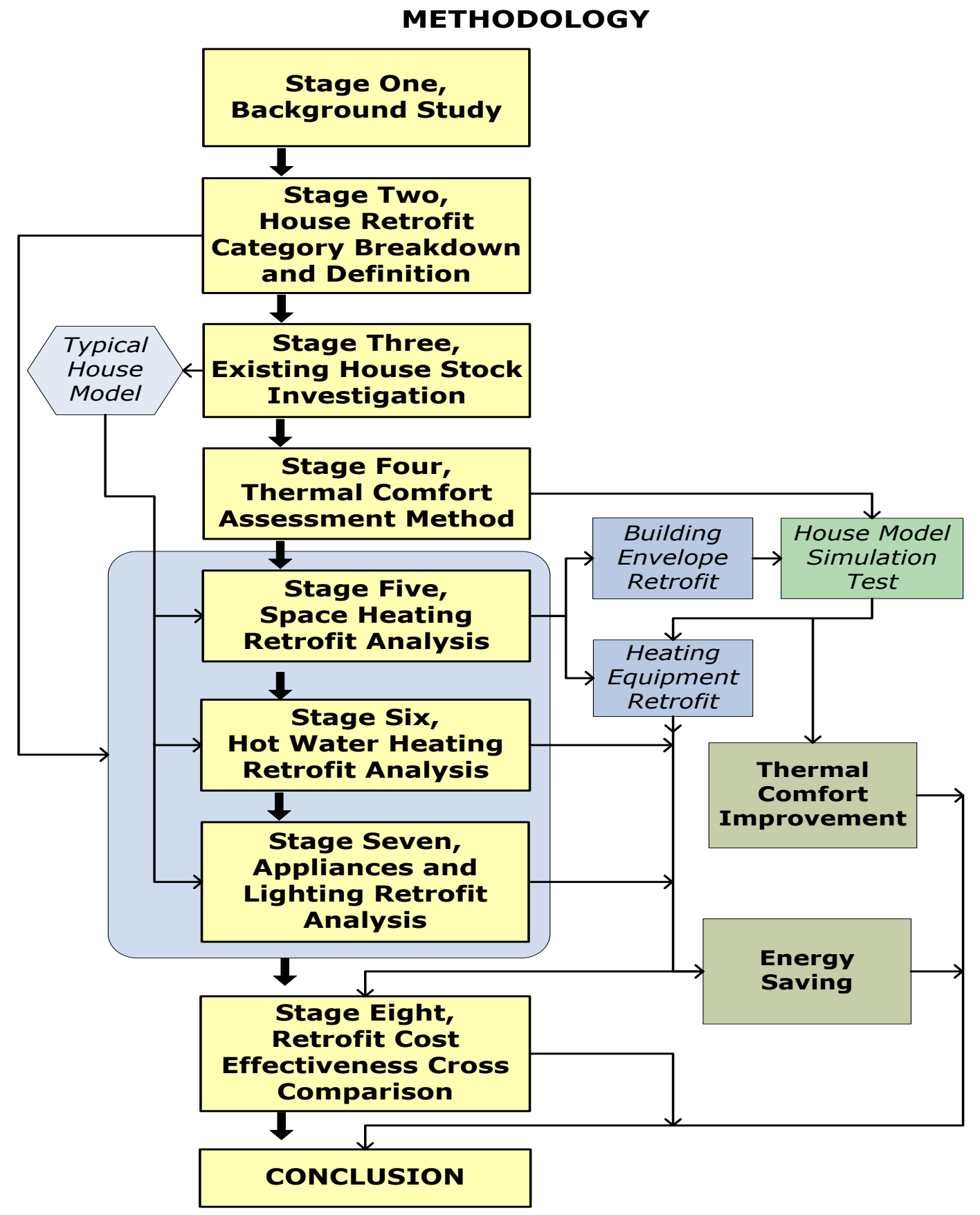

Figure 1: Research Methodology Flowchart 
This research was carried out in the following stages:

Stage One: Background study. A literature review was undertaken to investigate why house retrofit work is needed and how it has been carried out over the years in New Zealand.

Stage Two: House Retrofit Definition. House retrofit can be involved in a wide range of activities, which give various benefits to occupants or the house owner. This research concentrates on the retrofit work which is related to energy efficiency and thermal comfort. This study subdivided retrofit works into three main categories and gave definitions specifically for each type of retrofit work.

Stage Three: House Stock Investigation. To understand the current house retrofit features and make improvements, the New Zealand house stock was investigated. Different house characteristics, which affect retrofit efficacy, were found. A typical house was defined as a sample for further testing.

Stage Four: Thermal Comfort Assessment Method. To analyze house retrofit efficacy in thermal comfort improvement, it is important to determine assessment method. A series of approaches were reviewed.

Stage Five: Space Heating Retrofit Analysis. This section includes building envelope retrofit and space heating equipment retrofit study. To have a systematic understanding of building fabric retrofit, a series of detailed building thermal simulations were completed using the defined house model and modeling assumptions. The results in heating energy and indoor temperature indicate the efficacy of 
different building fabric retrofit measures. By using the simulation results of heating requirement, suggestions for space heating equipment retrofit were given.

Stage Six: Hot Water Heating Retrofit Analysis. The BRANZ HEEP project monitored household energy use database gave figures used for hot water heating retrofit analysis. Energy saving and cost effectiveness for different retrofit solutions were also calculated.

Stage Seven: Appliances and Lighting Retrofit Analysis. New Zealand average household energy use data from the HEEP report was used for appliances and lighting upgrading. Retrofit solutions for each section were given. Energy saving and cost effectiveness for different retrofit solutions were also calculated.

Stage Eight: Cost Effectiveness Cross Comparison. This section collected up the results from the above separate retrofit studies and analysed them in terms of cost effectiveness cross comparison. The proposed retrofit options were discussed with the results of the calculations. 


\section{Structure of This Thesis}

This thesis is divided into sixteen main chapters. The following section gives an overview of each chapter.

Chapter 1 consists of the Introduction, which gives an overall description of this work;

Chapter 2 gives context and objective of this study;

Chapter 3 describes the research method that was carried out for this study;

Chapter 5 gives literature review and explains why house retrofit should be necessary for existing houses to reach a high level of energy efficiency and comfort. Some New Zealand house retrofit studies were also reviewed in this section;

Chapter 6 describes how house retrofit work is divided into three categories.

Definitions of each type of retrofit were given;

Chapter 7 investigated New Zealand house stock. Typical house model was defined by the summarized house physical characteristics;

Chapter 8 reviews and discusses variables affecting thermal comfort. Assessment method is given in this section;

Chapter 9 explores insulation status of existing houses and discusses insulation retrofit package;

Chapter 10 described how thermal simulation study was carried out and analyses thermal simulation results. The outcomes are compared by space heating requirement comparison and thermal comfort 
assessment. Cost effectiveness calculation for each building element retrofit option is given;

Chapter 11 gives the recommendation for space heating equipment. Different types of heating equipment are compared;

Chapter 12 analyses hot water heating system of existing houses and gives recommendation for retrofit;

Chapter 13 gives retrofit recommendations for appliances and lighting. Also, cost effectiveness calculation for each of the retrofit options is given;

Chapter 14 presents the findings of cost effectiveness cross comparison of different retrofit solutions;

Chapter 15 gives conclusion of this study;

Chapter 16 suggests future study. 


\section{House Retrofit - Literature Review}

House retrofit has been a common subject for house owners and governments. Storey (Storey et al, 2004, p.10) estimated that $\$ 5,300 \mathrm{M}$ is spent on renovations, improvements, decoration and maintenance each year by New Zealanders. The Taylor Nelson Sofres Pty (TNS) survey also found that $60 \%$ of respondents said that they had undertaken home improvements in the previous 12 months (Storey et al, 2004, p.10). Appearance normally acts as the main driver for people to do house upgrading work. In the recent years, attention has been given by the media to global warming and energy poverty. Householders have more awareness of house retrofit technology, which can lower energy use and make an existing house warmer. The interest in home upgrading is steadily shifted from house aesthetics-cosmetic retrofit to house sustainable retrofit energy saving and thermal comfort, as more and more New Zealand householders realise appearance is not everything.

House retrofit covers a number of subjects, ranging from technical to human behaviour matters. Designers, construction and users are believed to be three primary and equally important factors which interact to affect how a building works (Mithratatne et al, 2007, p.197). For house retrofit circumstances, technical matters include the building design, construction and materials selection. In a broader scale, technology also covers the operating energy efficiency of home lighting, appliances and service equipment. Besides, one of the very influential factors in relation to the efficacy of house retrofit, and often not given sufficient emphasis, is the occupants of houses. Occupants play a big role for energy efficiency after the retrofit work is completed. Over the rest of the life of the building occupants will create the pattern for how home heating and 
other appliances are operated. The demand of the occupants drives the energy use. Also, people have similar needs but with wide variations. So, human behaviour and the choices they make also affects the energy retrofit efficacy.

\subsection{The need for existing houses retrofit}

In New Zealand, one of the commonly held beliefs is that many houses are cold, damp, mouldy and expensive to heat. The Building Research Association of New Zealand (BRANZ) has carried out some studies and demonstrated that New Zealand houses tend to be severely inadequately heated. With the expectation of indoor temperature improvement, householders may increase space heating energy consumption.

Buildings play an important role in supporting the state of health. Currently, it is becoming increasingly clear that indoor air temperature and moisture levels have a very clear link to people's health. A warm house is very important for people's well-being, while New Zealand homes are under-heated by international standards. The $\mathrm{WHO}$ recommended level is $18-24^{\circ} \mathrm{C}$ for comfortable temperature (WHO, 1987, p.19). The national monitored temperatures are well below the WHO standard. The WHO report also stated that adverse health conditions, such as, respiratory infections and disease, begin to occur at $16^{\circ} \mathrm{C}$ or below, with more severe circulatory disease risk near $12^{\circ} \mathrm{C}(\mathrm{WHO}, 1987$, p.20).

Yet many research results have showed that New Zealand homes are not warm enough, and below the World Health Organization's recommended minimum indoor temperature. The HEEP (Household Energy End-use Project) project found out that average winter evening temperature of living rooms is $17.9^{\circ} \mathrm{C}$, and the range is from $10^{\circ} \mathrm{C}$ to $23.8^{\circ} \mathrm{C}$ (Isaacs et al, 2006, p.V). This 
temperature range is lower than that found in countries with similar temperate climates. French discovered that living rooms are below $20^{\circ} \mathrm{C}$ for $83 \%$ of the time over the winter period. The living room is normally the warmest room (French et al, 2006, p.2). In the aspect of space heating patterns of New Zealand houses, Cunningham et al $(2001$, p.3) discovered that New Zealanders heat their houses intermittently and usually heat only the living areas leaving bedrooms quite cold in winter.

Emphasis has been placed on the thermal environment of residential buildings in New Zealand, looking at ambient indoor temperatures, household energy end-uses, and how temperature and humidity impact on housing and occupants' health. The School of Medicine and Health Sciences, Otago University undertook a research study in cost-benefit evaluation of housing insulation. This study evaluated the benefits from housing insulation, health gains and energy savings. It has found the overall result of a benefit-cost ratio close to 2 (Howden-Chapman et al, 2004, p.22). This means that $\$ 1$ invested in insulation installation will give $\$ 2$ worth of energy savings and health benefits, which include reduced hospitalizations and avoided days off school and work.

Amitrano et al (2006, p.2) discovered that three particular life stages provide special drivers and opportunities for home upgrading. Those are family with young children, family with teenaged children and couples about to retire. It is believed that more stable and comfortable indoor environment is the main driver of upgrading the house during these three particular periods.

In the New Zealand context, a building must be constructed to achieve an adequate degree of energy efficiency when that energy is used for cooling, heating and other miscellaneous building services. Basically, the thermal mass 
level and building insulation level must meet or exceed the requirements of the New Zealand Building Code. To put it more specifically, architects are supposed to design a certain level of insulation, and, to a lesser extent, thermal mass. Currently, acceptable methods for determining the thermal resistance (R-values) of building elements are contained in NZS 4214 and in the BRANZ House Insulation Guide (Department of Building and Housing, 2007A).

Apart from reduced energy use and higher levels of thermal comfort, Mithraratne et al indicated that increased levels of insulation make other impacts, such as affecting humidity in the internal spaces, reducing the potential mould growth and also increasing the durability of the structure and finishes (Mithraratne et al, 2007, p.54).

A house is a special type of building; the demands of the occupants drive the energy use. Without energy demand there is no reason for energy supply. Isaacs et al (2006, p.1) indicated that people do not actually want energy, but they want the services that energy can provide. Yohanis et al (2008) believed that the demand for energy in the residential sector is affected by not only socio-economic and cultural patterns of household heating but also local factors such as architectural features and building materials. House retrofit provides major opportunities to improve on the performance of the original design. House retrofit also gives rise to the chance to reduce heating energy through the incorporation of insulation materials. It is possible to undertake insulation retrofit for buildings in situations where the energy performance is even very poor to reduce running costs. The benefit of increased levels of insulation is that they may lead to a reduction in the use of space heating energy or an increase in comfort, or a combination of both. 
Worldwide, buildings' energy use takes up $40 \%$ of primary energy and accounts for $24 \%$ of greenhouse gas emissions (IEA, 2009, p.1). In 2008, $12 \%$ of New Zealand total consumer energy use was in the residential sector (Ministry of Economic Development, 2009, p.12). Over the period 1990 to 2004, total greenhouse gas emissions have increased by about one third for the reason of increased use of natural gas and coal in electricity generation, and increased consumption of diesel and petrol for domestic transport (Ministry of Economic Development, 2005, p.2). Boardman (1991) defined Fuel Poverty as occurring when householders have to spend $10 \%$ of their income on all energy requirements to provide a healthy indoor environment, then they are considered to be in fuel poverty. Due to the difference of climate, fuel poverty varies with regional effect. Lloyd (2006) estimated that $6-8 \%$ of households in Auckland, but $26-32 \%$ of households in Dunedin, and overall $10-14 \%$ of New Zealand households were in fuel poverty in 2001. Currently, due to the rise of residential energy prices, it is believed fuel poverty will increase if household energy efficiency is not improved.

Both energy consumption and energy prices are increasing, and energy availability is decreasing in New Zealand (Elias, 2008, p.3278). \$2.48 billion was spent by households just on electricity (Ministry of Economic Development, 2009, p.12; 119). Much of this energy can be saved and homes can be warmer, drier and healthier by applying appropriate techniques of home retrofit.

O'Donnell (2008, p.6) mentioned a typical New Zealand house consumes $10,500 \mathrm{KWh}$ of energy per year; nearly all energy consumption has more or less environmental impacts, ranging from the creating of greenhouse gases in burning fossil fuels to direct effects on landscape by dams. Historically, New 
Zealand has a relatively high level of renewables in the national electric power generation system (by resources such as hydro, geothermal, wind) (Vale and Vale, 2001, p.1). This means electricity has a lower $\mathrm{CO}_{2}$ emission than in many countries. With the greater electricity demand of new housing development, some recently built power stations were constructed and generate power by fossil-fuel (natural gas). This also means that more non-renewable fuel will be consumed and give rise to increased $\mathrm{CO}_{2}$ emissions. One thing that cannot be avoided is that once energy has been converted into heat, it is gone forever.

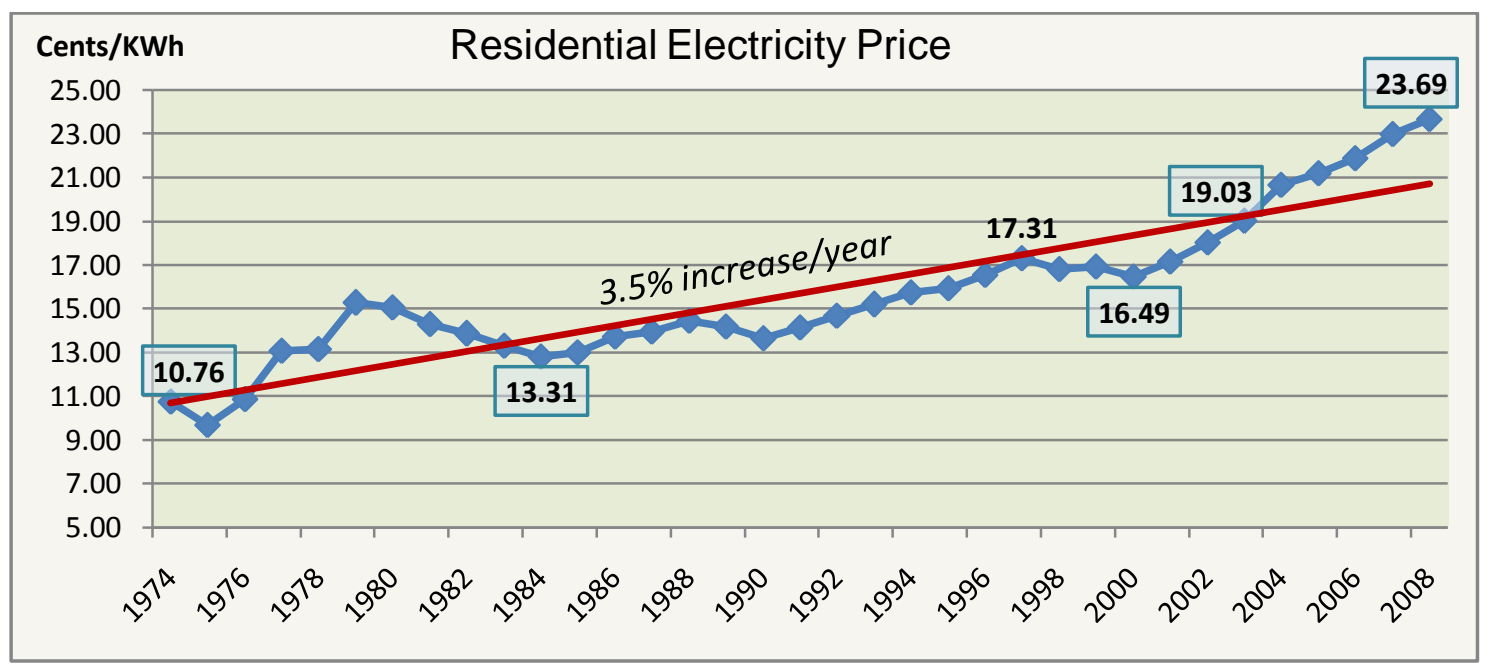

Figure 2 Residential Electricity Price, 1974-2008

(Data source: Ministry of Economic Development, 2008)

As Figure 2 presents, in the recent years, the residential electricity price increased dramatically at an average rate of $3.5 \%$ per year for the last three decades, between 1974 and 2008. Electricity price per KWh has increased by $144 \%$, from $\$ 0.10$ to $\$ 0.23$, more than double. All of the prices were converted to 2008 real price and including GST. The HEEP project found that electricity provides $69 \%$ of residential energy use (Isaacs et al, 2006, p.19) and the rest consists of wood, coal, natural gas and LPG. The electricity price is very unlikely to fall in the future. It will become more and more important to ensure homes are well configured and make the best use of energy. Currently, in 2010, 
domestic electricity price is getting close to $\$ 0.25$ per KWh (Ministry of Economic Development, 2010). This price is going to be used for the cost effectiveness calculations for this study. If electricity price continues to rise at the rate of the three decades, the energy price for twenty years later can be predicted as below:

Electricity price $\left(\right.$ in year 2030) $=\$ 0.25 / \mathrm{KWh} \times(1+3.5 \%)^{19}=\$ 0.48 / \mathrm{KWh}$

It is quite possible electricity price will be doubled in twenty years. Energy efficiency has moved on from being an issue of environment to an issue of people's daily life due to the increasing energy cost. Also, the efficacy of energy saving retrofit is very much depending on the price of electricity. More details will be discussed in the cost benefit chapter.

The HEEP project found, for a typical New Zealand house, space heating, hot water heating and appliances energy share almost equally the percentage of end use (Isaacs et al, 2006, p.19). These three components offer opportunities to make energy saving retrofit.

Normally, house occupants are less interested in energy use as such, but they are interested in a warmer indoor environment and the service by hot water, lighting and appliances. Winter (2009, p.38) mentioned that historically, New Zealand houses were very energy inefficient, and the current situation is that approximately 350,000 homes are poorly insulated or have no insulation. There is a close relationship between heating energy consumption and Insulation level. Fourier's Law gives a calculation formula (Addington and Schodek, 2005, p.64) for the rate of heat transfer through a material as below: 


$$
Q=(U \times A) \Delta T
$$

Where, $Q$ : heat transfer rate;

U: conductance;

A: area;

$\Delta T$ : inside and outside temperature difference.

Fourier's Law shows how the heat transfer rate is determined by the conductance property of the material and temperature difference between inside and outside. The heat transfer rate represents the amount of energy exchanged or transmitted by the material. For an existing building, the variable of area is normally fixed.

If the average ambient temperature is $14^{\circ} \mathrm{C}$, and the inside is heated to $18^{\circ} \mathrm{C}$, the heating energy required to maintain this $4^{\circ} \mathrm{C}$ difference is determined by the level of thermal resistance of the building envelope. If the building insulation is unchanged but outside temperature drops or the inside temperature rises by $1^{\circ} \mathrm{C}$, the $\Delta \mathrm{T}$ becomes $5^{\circ} \mathrm{C}$, a $25 \%$ increase in heating energy requirement to achieve a $1^{\circ} \mathrm{C}$ change in temperature difference $\left(4^{\circ} \mathrm{C}\right.$ increases to $\left.5^{\circ} \mathrm{C}\right)$. If all households make the houses to be just a little warmer in winter without increasing the level of insulation, the implications for national energy use, the cost of energy to the households, and even probably New Zealand's greenhouse gas emissions would be considerable.

Therefore, the first step to start saving energy would be cutting down wastage in the system. Energy demand should be minimised. The next stage would be to ensure that the energy is delivered with maximum efficiency. It is necessary to develop some house upgrading solutions and make the best possible use of energy for the current residential sector, rather than simply continuing to consume more and more. 
Under the above circumstance, it is advisable to consider the use of retrofit techniques that minimise the need for space heating while permitting the maintenance of comfortable and healthy indoor temperatures.

From the energy conservation standpoint, building envelope retrofit is only related to space heating energy, which only accounts for $34 \%$ of average household energy consumption in New Zealand (Isaacs et al, 2006, p.19). Approximately two thirds of household energy is consumed by water heating, appliances and lighting system. This means insulation retrofit is not enough to achieve overall house energy efficiency. House retrofit should be treated as an overall process with holistic approaches, rather than being only focused on the building fabric. Thus, it is necessary to introduce water heating, lighting and appliances as part of home retrofit works. It is believed that further energy saving can be made by adopting this approach.

Generally, retrofit of water heating, lighting and appliances means the need to upgrade facilities with high energy efficiency ones. However, some simple measures can also reduce energy use. Harris et al (1993, p.26) gave the following suggestions for domestic electricity use and estimated up to $13 \%$ reduction could be made with the simple measures:

a) Reducing hot water cylinder temperature to $55^{\circ} \mathrm{C}$ (6\% saving);

b) Use of low-flow shower heads, kitchen and bathroom taps, and cylinder wraps $(5 \%$ saving);

c) Cold water clothes washing ( $2 \%$ saving).

\subsection{New Zealand work}

House insulation has been mandatory in New Zealand since 1978, and the required levels have been revised a few times after that. But this is only the 
base level for new constructed buildings. Better thermal performing houses should be encouraged with higher levels of insulation.

Brenda Vale and Robert Vale completed one house extension project in Waiheke Island, Auckland (Vale and Vale, 2001). The original house was built in the early 1980s. The purpose was to test a method of construction that would have potential savings in space heating. Similar to the original house, conventional timber frame construction method was used for the extension area. The difference is that all of the extensions were designed and built with very high level insulation compared to the current Building Code requirement. 150 mm thickness of Pink Batts glass fibre was used in both floor and roof. In addition an extra layer of $50 \mathrm{~mm}$ polystyrene was fitted in between roof purlins. For walls, $50 \mathrm{~mm}$ thick and $600 \mathrm{~mm}$ wide expanded polystyrene sheets were installed between $50 \mathrm{~mm} \times 75 \mathrm{~mm}$ horizontal timber rails, which were fixed at the outside surface of the studs, with $90 \mathrm{~mm}$ Pink batts between the studs. The new windows were aluminium frame and incorporated double glazing with low emissivity coating on the outer surface of the inner pane (Vale and Vale, 2001).

The winter temperature of the bedroom was monitored. Generally, it was maintained between $15{ }^{\circ} \mathrm{C}$ and $20^{\circ} \mathrm{C}$, without using any space heating. One of the main findings of this project is that the approach of increased insulation could allow occupants to live at more comfortable temperatures without changing the pattern of household space heating or the basic methods of construction.

It is believed that similar comfortable temperatures can be achieved with no heating, if a similar light weight house is retrofitted with high level insulation. But, it should be noted that the Vales' extension project was located in Auckland, 
which is located in the northern part of New Zealand. A certain level of heating may be needed to maintain comfortable temperature, if the house extension is carried out in the southern region.

There has been speculation that passive means of house retrofit might be sufficient to improve indoor temperature.

In year 1998, one pilot test was carried out by Malcolm Cunningham, one of the BRANZ staff. This is an ordinary New Zealand timber framing house clad with rustic weatherboard, first built in 1929. The house was located near Wellington. The purpose of this retrofit study was to test how dust-mites were controlled by changes in indoor humidity, which is affected by house insulation retrofit. The insulation retrofit work was carried out in two stages. Ceiling and floor insulation was done in 1998, and wall insulation finished the following year. Humidity and temperature were monitored after the retrofit work. Cunningham et al (2001, p.1) discovered that humidity dropped from $65 \%$ to $60 \%$ after the first stage, and then from $60 \%$ to $59 \%$ after the second stage. The yearly average indoor to outdoor temperature difference increased from $0.5^{\circ} \mathrm{C}$ to $2.1^{\circ} \mathrm{C}$ after the first stage, and then rose to $2.9^{\circ} \mathrm{C}$ after the second stage. Eventually, this study concluded that passive techniques might not be sufficient to make enough change in temperature and humidity. However, the insulation levels used in this project were quite modest.

So far, the largest and the most intensively monitored insulation retrofit study in New Zealand was conducted by the Department of Physics, University of Otago. Insulation and some other energy-efficiency retrofit work were undertaken for 111 state houses in the Southern region of New Zealand. The project observed a small increase of around $0.4^{\circ} \mathrm{C}$ in yearly average indoor temperatures and 
$0.6^{\circ} \mathrm{C}$ over the winter period. Electrical energy consumption decreased between $5 \%$ and $9 \%$, after the house retrofit (Lloyd et al, 2007, p.A). This is believed to be the most accurately monitored retrofit project. This project did not achieve very much change in temperature and energy use. This is likely to have been because firstly, some houses already had some insulation installed, especially for the ceiling area. This made the efficacy of the retrofit work at a low level. Secondly, in the southern part of New Zealand, basic level ceiling and floor insulation made it hard to heat houses to $\mathrm{WHO}$ recommended $18^{\circ} \mathrm{C}-20^{\circ} \mathrm{C}$ without increasing energy consumption.

HEEP monitored results suggest that energy savings are hard to achieve from insulation retrofit and estimated saving in energy consumption is roughly $5 \%$ (Hindley and Pringle, 2009, p.7).

The Housing and Health Group conducted a research project and demonstrated that, when a house is made warmer and drier, the health of occupants improves. A totally of 1350 houses were selected around New Zealand (Cunningham, 2008, p.59). These house samples were divided into two groups: Retrofit group and Control group. For the retrofit group, insulation was installed in the ceiling, foil under the floor, polythene ground cover and draught stopping around windows and doors. With yearly monitoring, $0.6^{\circ} \mathrm{C}$ average temperature increase was observed in the retrofitted houses. Although this is not a very remarkable change in thermal comfort, it was believed that indoor comfort was improved significantly for the reason of shortening exposure to very cold temperatures. Daily hours of below $10^{\circ} \mathrm{C}$ reduced from 3.25 to 2.26 hours (Cunningham, 2008, p.59). This insulation retrofit study discovered that electricity and gas energy savings were around $13 \%$, compared with the 
controlled groups (Howden-Chapman et al, 2009, p.3398). This result indicated householders are likely to make considerable savings in energy consumption after insulation retrofit.

Summarizing all of the house upgrading works described above, only the Vales' house extension work achieved high performance of thermal comfort and heating energy reduction. Other studies either make minor or no improvement. These studies indicate that retrofit efficacy can be significantly affected by climate and the insulation level applied for the existing houses. The average annual outdoor temperature is $10^{\circ} \mathrm{C}$ in the south and $16^{\circ} \mathrm{C}$ in the north (Lloyd, 2007, p.2). This $6^{\circ} \mathrm{C}$ temperature difference makes a big difference in the likely improvement between the north and south part of New Zealand. Besides, only the Vales' study applied a high level of insulation, and other home upgrading work just installed a very limited level of insulation, which only reached the Building Code requirement. The above two research works indicate that efficacy of house insulation retrofit varies and is dependant both on the different building locations, and the existent situations. It is also believed that, to reach a satisfactory thermal comfort and energy efficiency level a higher level of insulation is needed for house envelope retrofit, including all building elements, and an energy efficient heating system is also essential to this target.

Therefore, the efficacy of retrofitting solutions to New Zealand houses is very important to improve thermal comfort and energy efficiency of the current housing stock. Government policy and house upgrading investment decisions also will need to be made depending on the retrofit efficacy. On a larger scale, house retrofit efficacy also affects power generation and transmission, air quality and $\mathrm{CO}_{2}$. 
Beacon Pathway has conducted a series of house retrofit studies in recent years. The project was targeted to make $90 \%$ of NZ homes use energy efficient systems for water heating, space heating, lighting and appliances, and have a high standard of insulation (to maintain minimum temperature of $18^{\circ} \mathrm{C}$ ), by 2012 (McChesney et al, 2008, p.1). However, Storey et al (2004, p.12) believed that Beacon's target for this sector was extremely ambitious. A comprehensive coordinated work plan was needed urgently to tackle all building industry areas, including local authorities, professionals and house owners. Although Beacon's target was hard to achieve, it did point out a clear direction for home retrofit.

\subsection{Occupants' behaviour effect in house retrofit--Rebound Effect}

Home retrofit solutions are supposed to lessen energy consumption and improve comfort level. However, it appears that energy efficiency improvement has not been always effective in reducing the environmental impact of houses. Potential gains from increased energy efficiency in any sector can be frustrated by the complexity of human behaviour, including 'take-back' or 'rebound' (Howden-Chapman et al, 2008, p.1).

There is growing evidence showing that lower levels of energy saving than expected occur due to a trade-off between taking the savings as thermal comfort rather than cutting down the energy consumption. Milne and Boardman (2000) discovered that a significant proportion of the benefit of energy efficiency improvement was taken as comfortable temperature increase. Also, they concluded that as indoor temperatures increased, the proportion of energy efficiency benefit increased, and energy efficiency improvement was completely taken as energy saving if indoor temperature reached $20^{\circ} \mathrm{C}$. 
In New Zealand, the first house retrofit study probably was completed by the Department of Statistics in 1972. Two groups of houses were compared. One group was insulated, and the other uninsulated. An unexpected result was found; the insulation retrofitted house group used higher heating energy. It is more likely that the houses were located in the southern region and the occupants heated the houses more extensively (Department of Statistics, 1973). When house retrofit is made more energy efficient, occupants are likely to take advantage of the better thermal performance of the building, which reduces the energy consumption, and use more space heating.

Beacon Pathway Ltd conducted one house retrofit project at Waitakere, Auckland. It has been monitored for energy and water use after completion of the house upgrading work. Eaton et al (2008) found out that during the first year, the household energy use appeared to be substantially reduced with financial savings. At the beginning of the second year, energy consumption increased with new appliances introduced into the dwelling. Part of the reason might be that occupants used the dwelling as home office and extended heating hours.

Sorrell gave the definition of output effects and re-spending effects, which can make good explanation of the above New Zealand rebound effect cases respectively. For output effect, cost saving from energy-efficiency improvements is used to increase output, thereby increasing consumption of energy to provide. Re-spending effects occurs, if consumers use the cost savings from energyefficiency improvements to purchase other goods and services which require energy to provide (Sorrell, 2009, p.1457).

In a UK study, Boardman (1994, p.93) indicated that after energy efficiency improvements are applied to warm houses, householders' income level affects 
the trade-off of energy reduction and temperature increase. In this study it suggested that overall the benefits would be divided into higher percentage of energy reduction (70\%) and lower percentage of improvement in thermal benefit (30\%). For low income homes, the division would be $40 \%$ of energy savings and $60 \%$ improvement in thermal comfort. Howden-Chapman et al completed one house upgrading study and discovered that nearly two thirds of householders prefer to take all or most of the house insulation benefit as warmer indoor temperature and only $16 \%$ of them chose to take the benefit as energy savings (Howden-Chapman et al, 2009, p. 3394).

To sum up, house retrofit measures are likely to achieve reduction in demand for space heating energy and offer benefits in health and well-being. Also, the trade-off between energy saving and comfortable temperature improvement does exist and greatly depends on occupants' operation choices. To make New Zealand houses move towards a higher degree of energy efficiency and comfort, engagement of dwelling owners is an important factor. A major difference between more energy efficient and conventional housing could be the ability of householders to operate their house in an efficient and comfortable manner. 


\section{Definition of Retrofit}

The definition of 'retrofit' is quite fundamental to this study. This chapter will review the meaning of retrofit work and define it in different categories. This is going to be used in the following sections of this study.

A 'retrofit' is defined by the Dictionary of Architecture and Building Construction (Davies and Jokiniemi, 2008, p.313) as:

"The addition of new building materials, building elements, and components, not provided in the original construction."

Generally, house retrofit is quite similar to house repair and renovation activities. In one Energy Retrofit Survey report, Saville-Smith (2008, p.15) mentioned:

"Internationally, investment into existing housing has traditionally been differentiated into three, albeit, frequently overlapping categories: house maintenance, repairs, and renovation. More recently, the term retrofit has been added to the range of investments made into existing dwelling stock. It is useful to differentiate these for analytic purposes."

"...renovation, refurbishment and rehabilitation is directed to enhancing the current performance and amenity of a dwelling, usually past its original specifications to the equivalent performance within more modern expectations of and capacity to deliver on improved dwelling performance and amenity...."

Storey (Storey et al, 2004, p.71) gave one other specific explanation of retrofit as 'any work carried out to a house subsequent to its completion' or narrowly as 'work undertaken to improve the original performance of the house, retrofit includes every kind of work on existing houses from decoration, through maintenance and repair, to restoration, renovation and rebuilding. It includes both consented and non-consented work".

Conventionally, house retrofit is concentrated on house interior or exterior appearance. Interior work is mainly targeted on kitchen and bathroom upgrading with modern and more functional design. Exterior activities include 
repaint and some maintenance work. A survey by Duggan (2004) indicated that appearance was the prime driver of home upgrading (about $60 \%$ of the renovations are appearance related). Winstone Wallboards, one of the largest New Zealand building material companies, completed a survey about home renovation in 2003. The result showed that renovation is more likely to be carried out soon after purchase with $37 \%$ of owners undertaking renovation within one year of purchase and $53 \%$ within two years of purchase (Duggan, 2004).

Nowadays, home renovation interest is steadily shifting to sustainable retrofit. People have more sophisticated understanding that aesthetics is not everything, but residential indoor condition plays a vital role in comfort, health and energy saving (Howden-Chapman et al, 2009, p.3388). In July 2009, the New Zealand government released a new Heatsmart Programme with $\$ 323$ million funding to retrofit 180,000 homes with insulation and clean-heating devices (TVNZ, 2009). The New Zealand Business Council for Sustainable Development (2009, p.1) conducted a survey which showed that $28 \%$, or about 280,000 homeowners intend to apply - 100,000 more than the government has planned for.

Housing modifies the natural environment and acts as a shelter. It is supposed to meet the needs of occupants' comfort and health. These needs can be summarised into four headings:

- Thermal- air temperature, humidity,

- Indoor Air Quality - ventilation for clean, fresh air,

- Visual- light, glare, work, romance, darkness,

- Acoustic- noise.

House retrofit measures can be developed based on the above occupants' demands. From the above list, thermal comfort is one of the most direct benefits 
of house retrofit. This is also one of the two main targets of this study. Another one is energy saving, which is described below.

Household energy usage can be divided into: heating, cooling and service. Heating includes space heating and hot water heating. Cooling includes food refrigeration and air cooling (if chosen by occupants, under New Zealand's temperate climate). Service energy is used for running lighting and operating a wide range of appliances, such as washing machine, TV, oven, toaster, microwave, etc. This part of energy is normally consumed as electricity and providing occupants various services for living, cooking or home entertainment. One feature of service energy is that $100 \%$ of the electricity energy is converted to heating, after the service is done (such as finishing mobile phone battery charging).

From a liberal interpretation, for this study, house retrofit is described as work carried out to improve the performance of energy efficiency and thermal comfort of a house.

From the expense point of view, energy related retrofit measures can be divided into: low cost approaches and expensive approaches. Cheap solutions typically include weatherstripping and draught stopping; cylinder insulation wraps and hot water pipe lagging; low flow water fittings; energy efficient light bulbs. These can make a real difference with a quick payback and minimal investment. Other retrofit enhancements cost more but can result in better comfort improvements and energy savings. These include, roof, underfloor and exterior wall thermal insulation; double glazing; replacement of flueless gas heaters; solar water heating; replacing low efficiency or faulty appliances with energy efficient equipment. 
Some of these retrofit enhancement approaches need to be designed to be carefully integrated into existing houses.

\subsection{Retrofit category breakdown}

HEEP is so far the largest and most accurate project in New Zealand house energy use. In New Zealand, on average, household energy use can be divided into three equal parts: space heating, hot water heating and the appliances.

Typical household energy use:

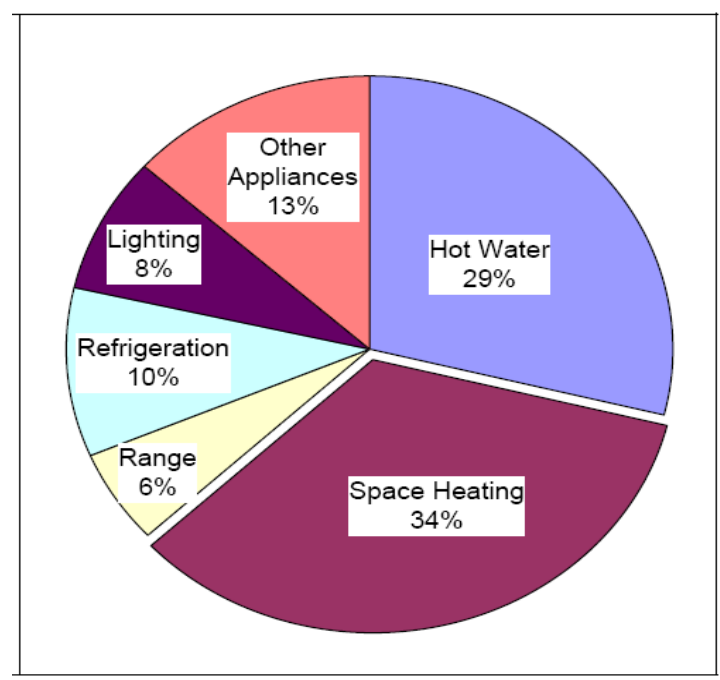

Figure 3: New Zealand Household Energy Breakdown by Average End Use (Source: Isaacs et al, 2006, p.19)

BRANZ research shows that average break down of household energy use can be divided into three roughly equal parts:

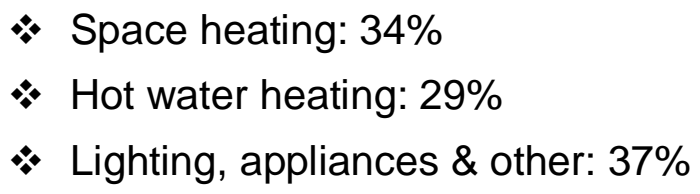

Space heating uses the largest part of total energy use, $34 \%$ on average. This is followed by hot water at $29 \%$. Lighting, appliances and refrigeration shared around $10 \%$ each (Totally $37 \%$ ).

The above household energy breakdown presents a clear picture of where energy is used in a New Zealand house. Also, this result indicates three very 
clear categories for house energy efficiency and thermal comfort retrofit:

A. Space heating retrofit

Basically, house heating demand has a very close inter-relationship with location and building envelope. The former provides heat gain, and the latter allows heat to be retained. The balance of these two factors plays a very important role in thermal comfort. To maintain a comfort level of indoor temperature and reduce space heating energy use, the building envelope should have less heat loss-meaning the need to increase the thermal resistance level. Also, space heating energy use will depend on the efficiency of heating equipment. Thus, space heating retrofit can be subdivided into two points: building fabric retrofit and heating equipment retrofit.

B. Hot water heating retrofit

This is an energy efficiency related retrofit, which counts for approximately one third of household energy use.

C. Appliances and lighting retrofit.

Appliances and lighting are big energy saving targets. With the development of new technology, the energy use of these two sections can have a potentially increasing trend in the proportion of overall household energy use.

To summarize the above retrofit breakdown, the three categories are tabulated below:

\begin{tabular}{|l|c|c|}
\hline \multicolumn{2}{|c|}{ Retrofit Category: } & Benefit: \\
\hline $\begin{array}{l}\text { A. Space heating } \\
\text { retrofit }\end{array}$ & a. Building envelope Retrofit & $\begin{array}{c}\text { Comfort Improvement } \\
\text { and } \\
\text { Energy Saving }\end{array}$ \\
\cline { 2 - 3 } & b. Heating equipment retrofit & Energy Saving \\
\hline \multicolumn{2}{|l|}{ B. Hot water Heating retrofit } & Energy Saving \\
\hline C. Lighting, Appliances and range retrofit &
\end{tabular}

Table 1: Retrofit Category Details. 


\section{Investigation of New Zealand House Stock}

It is believed that part of the household energy consumption is associated with house physical characteristics, such as size and age of the building, the construction type and material.

Wherever the location, a house can be thought of as a mixture of mass materials (e.g. concrete slab and brick wall) and insulation materials (e.g. expended polystyrene and fibreglass batts). Thermal performance of a naturally ventilated building depends on the mixture of these materials. To provide acceptable retrofit strategies, any proposal should follow normal New Zealand residential constructional practice. This section will investigate New Zealand house stock and identify house characteristics, which are related to house retrofit. Subsequently, a typical house model will be defined and will be used for retrofit efficacy test in the following sections.

In practice, the house retrofit process normally starts with an exploration of the existing home and its condition, the way the house was built and the materials that were used in its construction.

The initial investigation allows opportunity to consider the quality and integrity of the house's current form and fabric, before deciding what changes are needed to achieve better performance.

\subsection{House stock, type and size}

Generally, New Zealand house stock comprises largely lightweight timber frame buildings with minimal thermal mass. Storey et al (2004, p.7) estimated that New Zealand house stock is around 1.6 million units, with an average 30,000 houses increase every year. 
Amitrano et al (2006, p.46) estimated that out of the 1.6 million dwelling stock in New Zealand, 130,000 houses are sold every year. This comes out as an average of around 12 years for each house to be sold at least once. Also, Mithraratne pointed out that on average New Zealand houses change ownership around every 7 years (Mithraratne et al, 2007, p.6). Once a house gets a new owner, it provides an opportunity for house retrofit or other kinds of upgrading. Saville-Smith (2008, p.5) believes that the primary matter of changing the performance of the existing New Zealand housing stock is improving the energy performance of the existing stock.

The 2006 Census discovered, within the New Zealand house stock, 1.134 million, or $81 \%$ of occupied private dwellings, were detached houses (Statistics New Zealand, 2007, p.3).

\begin{tabular}{|l|c|c|c|}
\hline \multicolumn{4}{|c}{ Occupied Dwelling Type 1996, 2001 and 2006 Censuses } \\
\hline & 1996 & 2001 & 2006 \\
\hline Occupied private dwelling & & & \\
\hline $\begin{array}{l}\text { Occupied private dwelling, not } \\
\text { further defined }\end{array}$ & 9,686 & 113,885 & 74,334 \\
\hline $\begin{array}{l}\text { Separate house, no storey } \\
\text { information }\end{array}$ & -- & -- & 8,637 \\
\hline Separate house, with one storey & -- & -- & $\mathbf{8 6 3 , 8 7 7}$ \\
\hline $\begin{array}{l}\text { Separate house, with two or more } \\
\text { storeys }\end{array}$ & -- & -- & 261,852 \\
\hline Total Separate houses & $1,050,144$ & $1,030,077$ & $1,134,369$ \\
\hline $\begin{array}{l}\text { Two or more flats, units etc joined } \\
\text { together }\end{array}$ & 209,162 & 210,627 & 252,963 \\
\hline Other occupied private dwelling & 7,339 & 5,254 & 10,083 \\
\hline Total, occupied private dwellings & $1,276,331$ & $1,359,843$ & $1,471,749$ \\
\hline Separate house proportion & $82.9 \%$ & $82.7 \%$ & $81.2 \%$ \\
\hline
\end{tabular}

Table 2: Dwellings Type and Number Variation By Recent Years (Source: Statistics New Zealand, 2007, p.2) 
From Table 2, it can be seen that the quantity of detached houses has increased by 10.1 percent or 104,292 from 2001 . Table 2 also presents that the most common dwelling types by far are stand-alone houses, followed by attached houses. Multi-storey apartments have increased rapidly, but these are still a very small part of the total dwelling stock. Amitrano et al (2006, p.27) predicted that there will be more multi-unit dwellings developed than single houses, especially for the larger cities in New Zealand. Therefore, it can be concluded that the one storey detached house is the primary house type, which account for $76 \%$ of separate houses.

New Zealand has a quite similar house stock in terms of dwelling size and type although there is some variation in the aspect of style of house construction, materials and components. The current house stock fits into several dissimilar period and types, with different construction characteristics. Generally, it can be divided by the following house features:

--Architectural style;

--Construction material;

--Insulation status, pre or after 1978 mandatory policy.

Beacon Pathway has carried out a lot of house retrofit studies. One of their researches gave house typology breakdown as follows (Page and Fung, 2008, p.4):

- Early housing (pre-1890)

- Villa (1880-1920)

- Bungalow (1920-1935)

- Art deco (1925-1935)

- State house and mass housing (1930-1970)

- 1960s multi-units

- 1970s house (pre-1978 insulation)

- 1980s house (1978-1989)

- Early 1990s (1990-1996 before code upgrade)

- Last decade (1996-2007, after code upgrade) 
In addition, Page and Fung developed a house retrofit feasibility ranking system based on the house's physical characteristics, such as ease of access of ceiling and floor, construction features of wall and window, possibility to replace space heating system, etc. This research discovered that villas, 1920s bungalows and the 1940a to 1960s mass housing group were ranked top house groups in terms of retrofit favourability (Page and Fung, 2008, p.1).

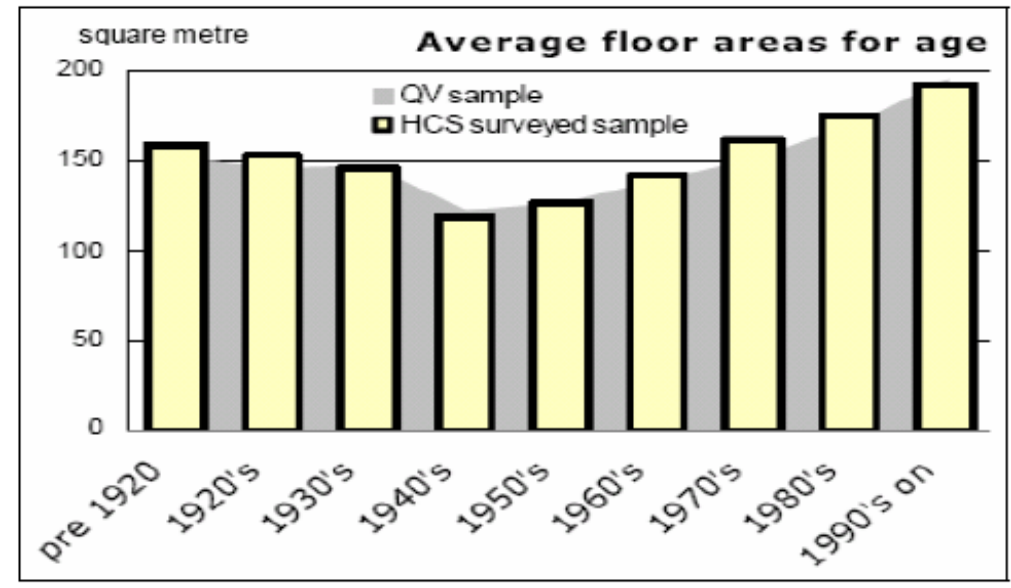

Figure 4: Average Floor Area by Age

(Source: Clark et al, 2005, p.5).

The average floor area of houses varies by age. The lowest average floor size happened in the 1940s. Since the 1940s, floor area has continuously increased from $130 \mathrm{~m}^{2}$ to nearly $200 \mathrm{~m}^{2}$ in the 1990s. This increase in house size is a worldwide trend in affluent economies.

\subsection{House construction types investigation}

In 2005, BRANZ conducted a house condition survey with 611 interview samples and 565 inspected samples around New Zealand. This survey (Clark et al, 2005, p.21) found out the following commonly used house cladding types:

$>$ Wall: Timber Weatherboard $-51 \%$

$>$ Roof: Galvanized Steel (painted) - 31\%

$>$ Window: Timber Frame - 44\% 
Mithraratne et al carried out research on life cycle analysis of New Zealand houses. To define common construction type of New Zealand houses, they investigated a large sample of trade brochures, specifications, product technical information for specialized building systems/materials, etc.

\begin{tabular}{|c|c|c|c|}
\hline Element & Item & Description & $\%$ \\
\hline \multirow{3}{*}{ Foundation } & & Tanalised timber piles & $21 \%$ \\
\hline & & House piles (timber/concrete) & $31 \%$ \\
\hline & & Reinforced concrete footings & $30 \%$ \\
\hline \multirow{4}{*}{ Floor } & & $\begin{array}{l}\text { Timber-framed suspended floor with } \\
\text { particleboard flooring }\end{array}$ & $65 \%$ \\
\hline & & Concrete slab floor & $35 \%$ \\
\hline & \multirow{2}{*}{$\begin{array}{c}\text { Floor } \\
\text { insulation }\end{array}$} & $\begin{array}{l}\text { Double-sided aluminium foil draped over floor } \\
\text { frame }\end{array}$ & $58 \%$ \\
\hline & & Polystyrene perimeter insulation & $8 \%$ \\
\hline \multirow{11}{*}{$\begin{array}{l}\text { External } \\
\text { walls }\end{array}$} & & Kiln dried light timber frame & $60 \%$ \\
\hline & & Double tongue \& grooved laminated timber & $29 \%$ \\
\hline & & Precast insulated concrete panels & $7 \%$ \\
\hline & & Steel frame & $4 \%$ \\
\hline & \multirow{3}{*}{$\begin{array}{l}\text { Wall } \\
\text { insulation }\end{array}$} & Glass fibre batts & $58 \%$ \\
\hline & & Polystyrene & $7 \%$ \\
\hline & & Double sided aluminium foil & $7 \%$ \\
\hline & \multirow{4}{*}{$\begin{array}{c}\text { Wall } \\
\text { cladding }\end{array}$} & Fibre cement weather board & $47 \%$ \\
\hline & & Brick veneer & $13 \%$ \\
\hline & & Timber cladding & $9 \%$ \\
\hline & & $\begin{array}{l}\text { Fibre cement backing board with } \\
\text { a finishing coat }\end{array}$ & $2 \%$ \\
\hline \multirow{6}{*}{ Roof } & \multirow{3}{*}{ Frame } & Timber truss & $53 \%$ \\
\hline & & Timber rafters \& beams & $36 \%$ \\
\hline & & Steel truss & $11 \%$ \\
\hline & \multirow{2}{*}{ Covering } & Corrugated steel & $87 \%$ \\
\hline & & Concrete tiles & $12 \%$ \\
\hline & Insulation & Glass fibre & $86 \%$ \\
\hline Joinery & Windows & Aluminium & $99 \%$ \\
\hline
\end{tabular}

Table 3: Frequency of Occurrence of Common Specifications.

(Source: Mithraratne et al, 2007, p.212)

The above table shows that $89 \%$ of external wall, $89 \%$ of roof structures and $65 \%$ of floor structures are built of timber. Timber elements form the structural system; from the thermal performance point of view, they also act as thermal bridges, 
which cause increased heat loss. But one of the features of timber structure is that it provides spacing in between timber elements. This gives the opportunity for insulation retrofit.

The BRANZ Household Energy End-use Project (HEEP) monitored energy use and indoor temperature data nationwide on 397 houses, which gives a statistically representative sample of New Zealand houses. A typical house in New Zealand was defined by French et al (2008, p.3) using the structural character breakdown of the 397 house samples as shown in the table below.

\begin{tabular}{|c|c|c|c|c|c|c|}
\hline $\begin{array}{c}\text { Building } \\
\text { Elements }\end{array}$ & Description & $\%$ & \multicolumn{3}{|c|}{ Others } \\
\hline Wall Cladding & $\begin{array}{c}\text { Weatherboard or } \\
\text { Brick Veneer }\end{array}$ & $75 \%$ & \multicolumn{2}{|c|}{ Others } & $25 \%$ \\
\hline Floor & Timber & $60 \%$ & Concrete & $30 \%$ & Others & $10 \%$ \\
\hline Roof Cladding & Long-run Steel & $61 \%$ & Tiles & $22 \%$ & Others & $17 \%$ \\
\hline Levels & One Level & $71 \%$ & Two Levels & $26 \%$ & Others & $3 \%$ \\
\hline
\end{tabular}

Table 4: HEEP House Samples Structural Character Breakdown. (Source: French et al, 2008, p.3)

\subsection{Typical building element construction of majority houses}

A typical New Zealand house is difficult to be simply defined. There are many confounding factors to be considered, such as floor areas, building materials, house age, etc. This study will specify a typical house by generic construction types of house elements. The summarized house model represents the most frequently used construction methods and designs and gives an overall picture of the general practice in the house building industry.

Therefore, based on the information collected from the previous section, the description is adopted for the most generic construction of a typical house model hereinafter referred to as 'one storey lightweight timber-framed 
construction with details as below:

- Particleboard floor on suspended timber framing;

- Timber framed exterior walls with weatherboard cladding;

- Pitched timber truss roof with corrugated metal cladding;

- Single glazing windows.

\subsection{House demolition and rebuild}

For some houses, particularly the older ones, there is no or little feasibility to retrofit or the cost to improve them to a reasonable better thermal performance level can be too high. This can be the consequence of two main reasons: poor maintenance and the age of the house. It may raise the question of demolition and rebuilding a new house with higher standard of performance.

BRANZ estimate that there are about $2000(0.13 \%$ of the total house stock) house demolitions every year (Page, 2008, p.33). This indicates that we are not so much replacing our housing stock as adding to it. This means that the problem with substandard houses is not fixing itself over time, but rather that as older houses deteriorate, the problems will get worse unless we take timely action.

Storey et al ( 2004 , p.55 and 18) mentioned that no official data have been collected on the numbers, age, location, condition, or the reason for demolition of NZ houses, and there are big variations in the estimated annual number of house demolitions (1000-7000). Little is known of the profile of the demolished houses, their age, type, size, location, ownership, etc. A survey to find out these factors would be valuable in assessing the impact of demolitions on the housing stock. 


\subsection{Building regulation change}

Since insulation became statutory in 1978, energy efficiency has been improved in new houses. The Building Act 2004 includes sustainability as one of its key principle and requires energy efficiency and conservation be taken into consideration for each clause of the new regulations (Storey et al, 2004).

\begin{tabular}{|c|c|c|c|c|c|}
\hline \multicolumn{5}{|c|}{ Schedule method component R-values for Zone 2 ${ }^{(1)}$} \\
\hline $\begin{array}{c}\text { Year } \\
\text { Commenced }\end{array}$ & Standard & \multicolumn{5}{|c|}{ R-Value $\left(\mathrm{m}^{2}{ }^{\circ} \mathrm{C} / \mathrm{W}\right)$} \\
\cline { 2 - 6 } & & Ceiling & Wall & Floor & Glazing \\
\hline 1978 & NZS 4218P:1977 & 1.9 & 1.5 & 0.9 & -- \\
\hline 2000 & NZBC H1/AS1 & 1.9 & 1.5 & 1.3 & -- \\
\hline 2007 & NZBC H1/AS1 & 2.9 & 1.9 & 1.3 & 0.26 \\
\hline
\end{tabular}

Table 5: Building Code Requirement of Building Elements R-values

(Source: Thermal insulation, BUILD. Isaacs, 2007, p.110)

From Table 5, it can be seen that the requirement of building element R-value has been gradually increased, since insulation became mandatory in 1978 . Insulation requirement for glazing was just introduced in the most recent (2007) Building Code upgrading. Compared with other building elements the R-value for glazing is significantly low. This is why glazing areas are normally very weak points for reducing heat loss. The HEEP project discovered that houses built after 1978 are averagely $1^{\circ} \mathrm{C}$ warmer than the ones built before 1978 . This result also showed the importance of government's Interventions in sustainable house development.

Older houses are not required to be upgraded to meet the current Building Code, but in some cases roof and floor have been voluntarily insulated the

\footnotetext{
${ }^{1}$ Definition of New Zealand climate zones can be found in Appendix A
} 
code required level. It is thus obvious that existing houses that do not have this level of insulation could be deficient.

Storey et al (2004, p.11 and 99) mentioned, of the existing 1.6 million houses, around 1.033 million were built before thermal insulation standards were introduced in 1978; meaning only about 120,000 of our houses are estimated to meet the upgraded thermal insulation standards which became mandatory in 2000. Howden-Chapman et al (2009) suggested that a proportion of dwellings built after 1978 do not have insulation even though required by the Building Code.

Although house insulation retrofit work is not mandatory by law, it should be encouraged that insulation installation needs to be combined with other possible building upgrading work. Storey et al (2004, p.8) pointed out that more existing homes will be modified for the needs of adults in the future, due to the rising trend of one person and couple household numbers; three types of renovations are most likely to happen to meet this demand in the future:

(a) Converting spare bedrooms into other uses like home offices and gyms.

(b) Adding bathrooms including en-suites for visitors.

(c) Dividing larger dwellings into smaller household units, with parts for rent.

These modifications provide opportunities for Insulation retrofit, when rewiring, plumbing, or relining work is necessary.

The recent Building Code was upgraded in 2008 with higher insulation requirements. Department of Building and Housing (2008, p.8) estimated that around $30 \%$ less energy is required to achieve comfortable indoor temperature for new homes (and extensions to existing homes). 


\begin{tabular}{|c|c|c|c|c|}
\hline Location & $\begin{array}{c}\text { Average cost of } \\
\text { constructing a } \\
\text { medium-sized } \\
\text { house pre changes }\end{array}$ & $\begin{array}{c}\text { Average } \\
\text { additional cost of } \\
\text { construction } \\
\text { after the changes }\end{array}$ & $\begin{array}{c}\text { Annual } \\
\text { saving in } \\
\text { energy bills }\end{array}$ & $\begin{array}{c}\text { Return period } \\
\text { on investment } \\
\text { (in years) }\end{array}$ \\
\hline Auckland & $\$ 254,000$ & $+\$ 3000-\$ 5000$ & $\$ 760$ & 7 \\
\hline Wellington & $\$ 254,000$ & $+\$ 3000-\$ 5000$ & $\$ 940$ & 6 \\
\hline Christchurch & $\$ 254,000$ & $+\$ 3000-\$ 5000$ & $\$ 1340$ & 4 \\
\hline Dunedin & $\$ 254,000$ & $+\$ 3000-\$ 5000$ & $\$ 1800$ & 3 \\
\hline
\end{tabular}

Table 6: 2008 Building Code Upgrading Before/After Construction Cost and Insulation Investment Return Period.

(Source: Department of Building and Housing, 2008, p.8).

Table 6 gives the comparison of construction cost of before and after 2008 Building Code upgrading. It estimated $\$ 3,000-5,000$ extra investment needed to meet the new requirement. It also noted that the return period of Dunedin is less than half of the one for Auckland. This is mainly because Dunedin is colder and more energy saving can be made than Auckland.

\subsection{New Zealand house envelope retrofit strategy}

\subsubsection{Light weight structure}

From the above investigations, it was concluded that the typical New Zealand house is mainly built of timber structure with weatherboard wall cladding and metal roof cladding. This means light weight structure is widely used for New Zealand houses. The reasons for this include the earth quake design requirements, New Zealand local timber productivity and historical use of timber for residential constructions.

To develop efficient retrofit solutions, the above house characteristics should be seriously considered.

In the 1970's, two approaches were introduced in the United States for lowenergy house design: "Mass and Glass" and "Light and Tight" (Vale \&Vale, 2000, p.69). For existing houses in New Zealand, the latter approach can be 
adopted. The reason is timber framing structure has been widely used in New Zealand houses, and based on the existing house design and construction, thermal mass level is hard to enhance by adding massive materials such as concrete. "Tight" can be explained as improving airtightness and thermal resistance, which contribute to retaining heat for the house. During the retrofit stage, it is hard to add mass to the building but it is often possible to add insulation.

\subsubsection{Insulation level}

New Zealand Building Code clause H1, Energy Efficiency-Third Edition (2007), specifies minimum levels of insulation to be achieved for new houses, and it does not require insulation to be applied to the houses constructed before the implementation date. However, to ensure better building energy performance, the R-value required by $\mathrm{H} 1$ can be used as a threshold level for building element insulation retrofit. It is recommended that, for house insulation retrofit, benefits to the occupants should be realized by providing more than the minimum. One of the fundamental rules adopted in this study is "applying as much as possible thermal insulation to the existing building envelope". This is believed to be a very efficient way to minimise heat loss. A cost effectiveness analysis will be given in the later chapter.

The house space heating energy requirement depends on the heat gains and losses through the fabric. A house's heat gain includes internal heat gain (from the sun, occupants and appliances heat) and mechanical heat gain (from heating equipment). Heat losses generally occur from five routes: roof, walls, floors, windows and air infiltration. Heat loss from the building fabric depends inter alia on thermal insulation and effects of ventilation. Therefore, for the best 
Investigation of New Zealand House Stock

house thermal performance, all of these aspects should be covered in the building envelope retrofit solution. 


\section{Thermal Comfort}

New Zealand houses are reported to be constantly below WHO (World Health Organisation) recommendations for indoor environments, showing that low temperatures are widespread in New Zealand houses. The WHO recommended comfortable temperature band is between $18^{\circ} \mathrm{C}$ to $24^{\circ} \mathrm{C}(\mathrm{WHO}, 1987$, p.19). French et al (2006, p.9) discovered that heating type, climate, and house age are the main drivers of indoor temperatures.

The HEEP project monitored the winter temperature for 397 houses around New Zealand, and found that the average winter living room temperature is $17.9^{\circ} \mathrm{C}$ with the mean range from $10^{\circ} \mathrm{C}$ to $23.8^{\circ} \mathrm{C}$ (Isaacs et al, 2006, p.V). In the southern region of New Zealand, one study found that occupants could be exposed to indoor temperatures below $12^{\circ} \mathrm{C}$ for nearly half of the day during the three winter months (Lloyd et al, 2006, p.B). These low indoor temperatures indicate that either the house heating is ineffective or there is little realized demand for heating, which may be for the reason of poverty or cultural preferences. However, Isaacs $(1998$, p.13) discovered that income is not a significant driver for house warmer house temperatures.

Under the temperate climate of New Zealand, house retrofit should improve thermal comfort by reducing heat loss and maximising heat gain in winter.

\subsection{Variables affecting thermal comfort}

Evans (1999, p.37-2) indicated that thermal comfort is dependent on temperature, humidity, radiation and air movement as well as activity, clothing and degree of acclimatisation.

Szokolay (2004, p.17) categorised the variables that affect thermal comfort into the following three groups: 
--Environmental (Including temperature, humidity, etc.)

--Personal (including activity, clothing, acclimatisation etc.)

--Contributing factors (including food and drink, age and gender etc.)

The latter two groups, personal and contributing factors, are significantly dependant on people's own subjective behaviour and status.

The routine approach to understand thermal comfort is the analysis of the environmental variables.

Traditionally, there are four primary separate environmental variables that interact in creating thermal comfort:

\begin{tabular}{|l|l|}
\hline D Air temperature, & Thermal radiation, \\
\hline D Humidity, & Air movement, \\
\hline
\end{tabular}

In a building, these four environmental factors are closely interdependent (Szokolay, 2004, p.17).

Air temperature is the dominant environmental factor, as it governs convective heat dissipation. Air temperature is normally measured by dry bulb thermometer and has been used as the primary variable for thermal comfort assessment. Generally, air temperature is mainly adopted as the only variable for thermal assessment.

Indoor humidity is dependent on the climate and air temperature. New Zealand is a humid country. In most regions, the air contains a lot of water vapor all year round. Also, moisture is generated by occupant activities (showers, cooking), by mechanical appliances (clothes driers, dishwashers, washing machines) and plants. Therefore, it is believed that all of the above variables make it hard to estimate humidity as part of thermal comfort assessment. 
Air movement affects space comfort by accelerating or decelerating convection. For a naturally ventilated house, air movement is greatly affected by the status of airtightness (Szokolay, 2004, p.60).

\subsection{Importance of MRT (Mean Radiant Temperature)}

Radiation exchange depends on the temperature of the room surrounding surfaces, measured by the MRT (mean radiant temperature). This is the average temperature of the surrounding surface elements, each weighted by the solid angle it subtends at the measurement point (Szokolay, 2004).

The MRT is normally not adopted in thermal comfort evaluation, because it is hard to be estimated. MRT cannot be measured directly, only by a black globe thermometer, which responds to radiant inputs as well as to air temperature. Then MRT can be calculated by the data collected (Szokolay, 2004).

In fact, radiation temperature acts in a significant role for thermal comfort, because the human body is a very effective radiator. The human body continuously produces heat by its metabolic processes. An adult working at a desk produces heat at about the same rate as does a 100-watt light bulb (Allen, 2005), but it can be different according to occupants' activities from about 70W (in sleep) to over 700W in heavy work or vigorous activity (Szokolay, 2004).

The human body uses radiation, convection and relative humidity to maintain its temperature, the perception of warm or cold is dependent on all these factors.

Thermal comfort is related to the thermal balance between heat gains due to the metabolism of the body and heat losses from the body to the environment. To maintain a comfort level of the human body, there must be a balance among the temperatures of the surfaces to which the body is exposed. A balance is 
also required among heat gains and losses by convection, conduction, and evaporation.

As evidence of the importance of radiant-heat exchange to the body's thermal equilibrium, Hall and Greeno estimated the proportions between these three heat loss factors as below (Hall and Greeno, 2007, p.79):

\begin{tabular}{|l|l|l|}
\hline Radiation $45 \%$ & Convection 30\% & Evaporation 25\% \\
\hline
\end{tabular}

It shows that approximately half of a person's heat transfer is through radiation. This proves the importance of MRT for thermal comfort. The general method for quantifying the effect of radiant heat is through mean radiant temperature. Consequently, humans are highly responsive to changes in MRT. Generally, for every $1 \mathrm{~F}$ MRT decrease, air temperature needs to be raised up by about $1.4 \mathrm{~F}$ to achieve similar comfort conditions (HPAC, 2010, p.1).

Therefore, to evaluate building thermal comfort, MRT should be considered as an important variable.

\subsection{Thermal assessment method}

At present, the commonly used model is the one that was given in Fanger's book Thermal Comfort (Fanger, 1970) and expressed by the Comfort Equation, which has been adopted by ISO as Standard 7730. In this model discomfort is attributed to an imbalance between a person's heat gains and heat losses. Fanger's calculation models of PMV (Predicted mean vote) and PPD (Percentage of Persons Dissatisfied) are the conventional method in thermal comfort assessment. However, some scholars have pointed out that the PMV model is not an accurate predictor of comfort in real buildings, especially for these with natural ventilation. Humphries and Nicol's study (2002, p.667) pointed out that the application of ISO 7730 frequently gives an incorrect 
evaluation of thermal discomfort and the PMV model overestimates the neutral temperature by around $3-4^{\circ} \mathrm{C}$ when the mean outdoor air temperature is $5-15^{\circ} \mathrm{C}$ - typical New Zealand winter temperatures. Therefore, it is believed that Fanger's comfort assessment model can be applied only for conditioned buildings rather than naturally ventilated ones.

Some researchers have adopted a thermal comfort index created by the combination of a weighted average between mean air temperature and mean radiant temperature.

For example Environmental temperature was given by Cowan and Smith (2004, p.110) with the following formula:

$$
\text { Environmental Temperature }=\frac{2}{3} M R T+\frac{1}{3} M A T
$$

Where MAT is Mean Air Temperature

It was also suggested that this formula is more suitable for warm climates and for situations where MRT is much different to MAT.

Effective temperature is another method using a different weighted average between air temperature and radiation temperature.

The effective temperature may be estimated as the following formula:

$$
\begin{aligned}
& \text { Effective Temperature } \\
& \qquad=0.42 \mathrm{MRT}+0.51 T_{\text {room }}+0.04 T_{\text {outdoor temperature }}+1.1^{\circ} \mathrm{C}
\end{aligned}
$$

This method can be used under a certain set of particular circumstances limitations, such as humidity, ventilation (Burns, 1992, p.90).

Again, currently there is not very strong evidence for the suitability of assessing comfort in a naturally ventilated building by the above two thermal comfort indexes. 
Therefore, this study will examine the mean air temperature and mean radiant temperature individually for thermal comfort assessment. 


\section{Building Envelope Retrofit}

Generally, in energy-related house retrofit situations, thermal mass, window size and position, orientation and location of existing houses are hard to modify. Therefore insulation upgrading is the major area for building envelope retrofit. The key benefit of building envelope retrofit is being able to reduce the amount of energy used for heating while maximising the internal comfort levels.

\subsection{Insulation}

Insulation is applicable in four main components of a building envelope: ceilings, walls, windows and floors.

Insulation works by reducing the transfer of heat by means of a thermal barrier. The measure of insulation level is expressed as heat flow resistance value (Rvalue). R-value or thermal resistance gives a measure of how difficult it is for heat energy to flow through part of a building.

The rate of heat transfer is inversely proportional to the R-value. Therefore for each building element, insulation level displays diminishing return effects (McChesney et al, 2008, p.2).

In an unheated house, the level of insulation will determine how much the temperature inside is raised above that of the environment.

Within a building, heat loss is determined by the total loss from each element of the building envelope, and the loss from each element is proportional to its area. Also, diminishing return principles apply to each building element. This means that insulated elements cannot be compensated by applying higher insulation level to other elements (McChesney et al, 2008). A modest level of insulation throughout all of the building elements is better than a high level in one building element and nothing in other ones, as heat will be lost at the uninsulated area. 
The same theory is applicable to the whole house- partially or uninsulated rooms will result in big heat loss. Therefore, from the whole building envelope point of view, all of the elements should have a certain basic level of insulation to achieve better performance, and partially or non-insulated elements should be avoided.

This principle plays a very important role in house envelope insulation retrofit, because numerous existing houses are only partially insulated in ceiling or floor. Clark et al (2005, p.44) found out that $15 \%$ of houses had either no ceiling insulation at all, or it was installed in less than half of the roof area. McChesney et al (2008, p.4) estimated that about 650,000 houses without floor insulation would be able to be insulated.

The potential for small trade-offs exists between the different building elements. This is believed to be the reason that three insulation options are given for each climate zone in the Schedule Method section, NZS 4218: 2009.

There are two main types of insulation: bulk Insulation and reflective insulation.

Bulk insulation has a wide variety of formats: blanket, loose fill, and rigid sheets. Reflective insulation normally has a shiny surface on one or both sides, which is designed to reflect radiant heat and reduce heat loss.

In recent years, insulation material price shows an increasing trend. This is one of the key factors which affect retrofit decisions and efficacy of insulation retrofit. Insulation costs include the costs of materials, transport, and installation. In practice, the only difference of insulation cost is insulation material and delivery. It is believed that the installation charge will not be very different for different thicknesses of insulation. By installing more insulation, for instance, a thicker 
layer for ceiling insulation, the thermal performance will be improved greatly with extra cost due only to the increased material cost.

In addition, insulation material durability is something of which one needs to be aware and it needs to be improved. Material that is insufficiently durable may cause insufficient insulation and cut down the thermal effect.

Regarding insulation status of existing houses, data from the BRANZ House Condition Survey (HCS) undertaken in 2005 is given as below:

\begin{tabular}{|c|c|c|c|c|}
\hline & $\begin{array}{c}\text { Full } \\
\text { insulation }\end{array}$ & $\begin{array}{c}\text { Partial } \\
\text { insulation }\end{array}$ & $\begin{array}{c}\text { No } \\
\text { insulation }\end{array}$ & $\begin{array}{c}\text { No access for } \\
\text { insulation }\end{array}$ \\
\hline Ceiling & $69 \%$, & $19 \%$ & $6 \%$, & $7 \%$ \\
\hline Wall & $29 \%$ & $16 \%$ & $56 \%$ & -- \\
\hline Suspended timber floor & $18 \%$ & $9 \%$ & $64 \%$ & $9 \%$ \\
\hline \multicolumn{5}{|l}{ Note: 60\% of accessible ceilings with insufficient insulation } \\
\hline
\end{tabular}

Table 7: Insulation Status from BRANZ House Survey 2005 Source: (BRANZ 2005 house condition survey. Clark et al, 2005, p.49)

This survey also discovered that some $60 \%$ of existing houses built prior to 1979 have been retrofitted with ceiling insulation. Storey et al (2004) estimated that around 25,000 pre-1979 houses have been retrofitted with ceiling insulation per year between 1976 and 1999 and subfloor insulation appears to have been fitted in less than $1 \%$ of these houses.

It is estimated that there were 1.6 million homes in New Zealand, with 1.04 million built before insulation was required by the Building Code (Amitrano al et. 2006, p.1). The pre-1979 homes are the largest part of the building stock. This also shows a huge opportunity in improving the energy efficiency of New Zealand dwellings by retrofitting insulation to a high level. In many houses, ceiling and floor improvements can be carried out quite easily as there is easy 
access for insulation. However, not all of ceilings and floors are accessible. Amitrano et al (2006, p.9) also gave the result of existing house insulation status with market segment as below:

\begin{tabular}{|c|l|c|c|}
\hline $\begin{array}{c}\text { House } \\
\text { Component }\end{array}$ & \multicolumn{1}{|c|}{ Type } & $\begin{array}{c}\text { Number } \\
\text { of } \\
\text { homes }\end{array}$ & $\begin{array}{c}\text { Percentage of } \\
\text { market } \\
\text { segment }\end{array}$ \\
\hline \multirow{3}{*}{ Roof } & Cavity-uninsulated & 631,810 & $61 \%$ \\
\cline { 2 - 4 } & Cavity-insulated to current code & 167,950 & $16 \%$ \\
\cline { 2 - 4 } & Skillion-uninsulated & 240,240 & $23 \%$ \\
\hline \multirow{3}{*}{ Wall } & Cavity-timber frame with cladding & 975,520 & $95 \%$ \\
\cline { 2 - 4 } & No Cavity-solid timber of concrete block & 648,480 & $6 \%$ \\
\hline \multirow{3}{*}{ Floor } & Suspended-uninsulated & 711,491 & $68 \%$ \\
\cline { 2 - 4 } & Suspended-insulated & 56,029 & $5 \%$ \\
\cline { 2 - 4 } & Slab on ground & 272,480 & $26 \%$ \\
\cline { 2 - 4 } & Suspended-too close to ground & 10,400 & $1 \%$ \\
\hline
\end{tabular}

Table 8: Insulation and Construction Type of Pre-1979 Dwellings (Source: Amitrano et al, 2006, p.9)

From Table 8 , it can be seen that $23 \%$ of roofs and $1 \%$ of floors cannot be directly retrofitted with insulation, owing to the access matter. To install insulation material for these ceilings and floors, more building works need to be involved, such as removing and restoring internal linings. The above table also shows $61 \%$ of ceilings and $68 \%$ of floors were uninsulated, but provided access for insulation retrofitting.

\subsubsection{Roof and ceiling}

The BRANZ 2005 House Condition Survey shows more than half of the sample houses were built with profiled metal roof claddings, and $69 \%$ of these samples have been fully insulated. In $60 \%$ of these houses ceiling insulation is insufficient. $7 \%$ of the house samples do not have access for insulation (Clark et al, 2005). 
The majority of houses have accessible roof spaces. But in houses with skillion roofs or low pitch roofs, access to the roof space is generally expensive, and insulation can be installed, only when it is needed to lift the roof covering for maintenance or renewal. It was estimated that $23 \%$ of houses could have skillion roofs, and while some of these houses may have part skillion-part roof cavity it is a potentially significant number of houses in total (McChesney et al, 2008, p.26).

Clark et al (2005, p.49) suggested that $60 \%$ of accessible ceilings were provided with insufficient insulation. Reasons for inadequate ceiling insulation vary, and can be the lack of cover, insufficient thickness, or a combination of both.

For the test house model in this study, it is assumed ceiling area is accessible and bulk insulation can be installed with the proposed details as below.

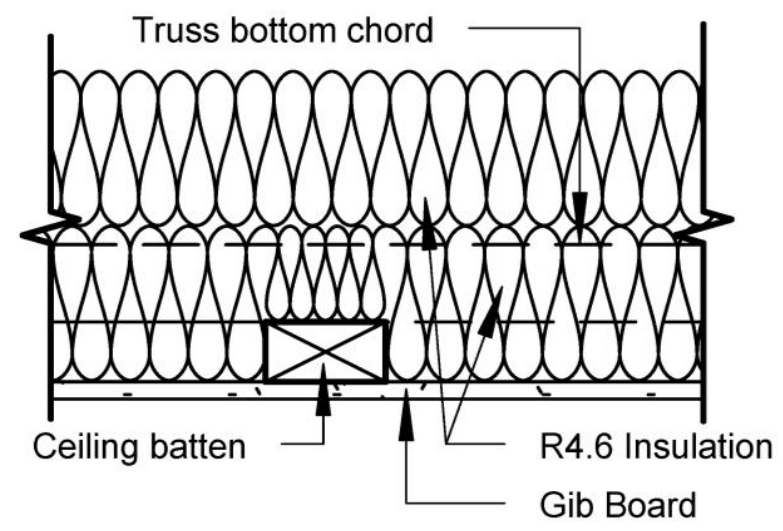

Figure 5: Ceiling Insulation Retrofit Detail

As Figure 5 shows, insulation level of R4.6 can be achieved by two layers of basic insulation or a layer of $195 \mathrm{~mm}$ thickness of PINK BATTS ULTRA (PINK BATTS, 2010).

\subsubsection{Wall}

Existing exterior walls are normally more difficult to retrofit with insulation than 
existing roofs and floors. Insulation retrofit can be fitted in both from outside or inside of the timber frame walls.

Insulation retrofit from inside can be carried out by stripping off the internal lining, generally GIB board and installing insulation in the gaps of the timber wall frame. But the drawbacks of this method are that more building work needs to be involved, such as reinstalling internal lining, repainting, and council's inspection. Although this option can be expensive, the new internal lining can improve the airtightness of the house, and the insulation installation and quality can be ensured. Considering the limitation of the space between timber studs and dwangs, the maximum thickness is $90 \mathrm{~mm}$. Therefore, R2.4 bulk insulation material can be installed.

Insulation retrofit also can be done from outside of the wall by filling the wall cavity with polystyrene beads or other insulation material, which is blown in through holes made in the wall cladding. Compared with insulation retrofit from inside, this option may save building work and make less disturbance to the occupants. Attention needs to be given for waterproofing the holes in the wall cladding.

AIRFOAM is one of these methods by filling insulation from outside of the exterior wall. Liquid foam is injected into the wall cavity through holes in the wall cladding. The AIRFOAM ${ }^{\mathrm{TM}}$ web site gives thermal Conductivity of $0.032 \mathrm{~W} / \mathrm{mK}$ at $20^{\circ} \mathrm{C}$ (AIRFOAM, 2010). Wall cavity is $90 \mathrm{~mm}$ deep. R-value can be calculated by $0.09 \mathrm{~m} /(0.032 \mathrm{~W} / \mathrm{mK})=2.8 \mathrm{~m}^{2} \mathrm{~K} / \mathrm{W}$. But thermal performance is criticized by some researchers. EECA (2010) believes the R-value of this product is hard to be estimated, and it is impossible to tell if a wall has been fully insulated or not. Therefore, this option can be only roughly estimated to 
give insulation around Building Code level.

A cost benefit analysis for above two wall insulation retrofit options will be given in the later chapters.

\subsubsection{Floor}

From the data given by the BRANZ house condition survey, floor insulation was less common, and nearly two thirds of floors were completely uninsulated (Clark et al 2005, p.49).

Most commonly used floor coverings are carpet and vinyl flooring for timberframed floors. For timber framed floors, double-sided draped foil over floor joists was most commonly used as insulation. But the performance of this material is debatable. In theory, this construction would provide an $R$ value of $1.4 \mathrm{~m}^{2} \mathrm{~K} / \mathrm{W}$. Isaacs and Trethowen (1985) discovered that 1 in 5 houses had foil insulation pulled too tight, which caused R-values lower than the expected design value. Besides, dampness and condensation also reduce the thermal resistance of the floor construction.

Nowadays, commonly used floor insulation retrofit materials are fibre glass bulk insulation or polystyrene sheet insulation. Both of these materials can be fitted in to the space between floor joists. Polystyrene is commonly either supported by a friction fit, or with clips. Bulk insulation can be supported by netting or a sheet of lining material fixed at the bottom of the floor joists. This sheet lining layer not only acts as support for the insulation material, but also helps to reduce air infiltration heat loss to the house. Normally, a layer of polythene is laid to cover the natural earth under the house to give some dampness control for the under floor area. 
Under floor access is essential for the above under floor retrofit work. Some houses are not likely to do this kind of retrofit because the suspended floor is too close to the ground. At least $400 \mathrm{~mm}$ deep space ${ }^{(2)}$ is needed for the installation of insulation materials.

Retrofitting insulation to an existing timber frame floor provides some extra benefits: improve airtightness, giving warmer floor surfaces and reducing condensation and mould risk.

This study gives the following proposed underfloor insulation retrofit solution.

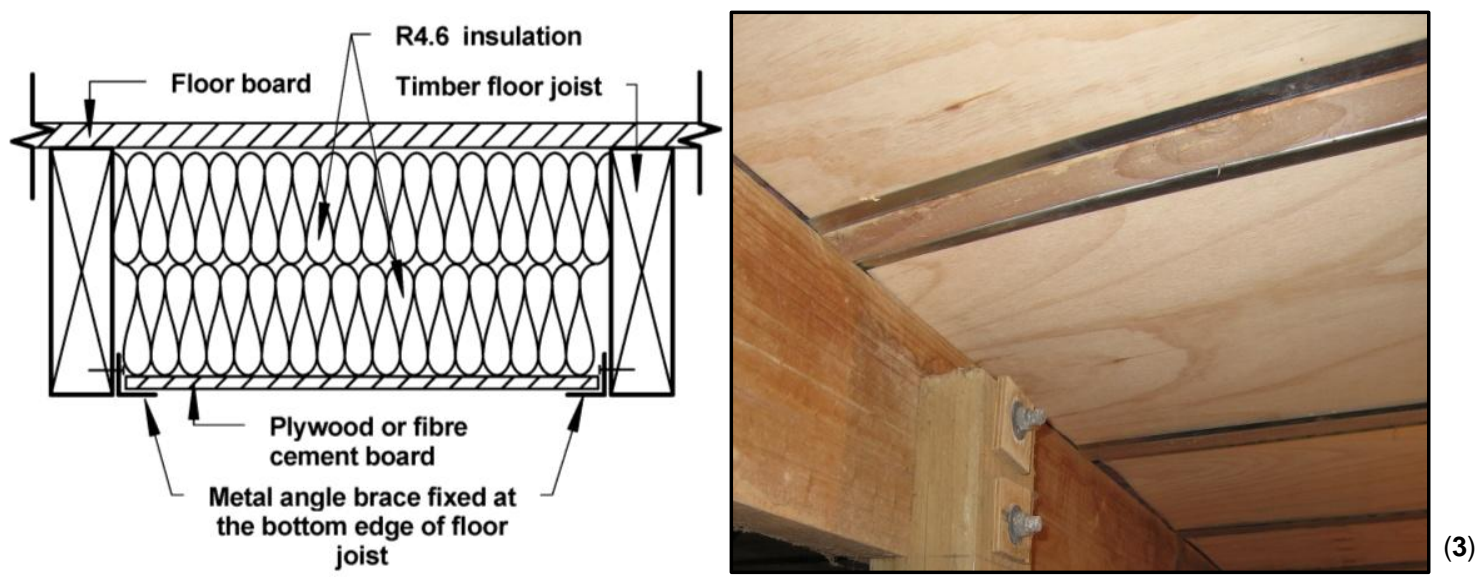

Figure 6: Proposed Underfloor Insulation Retrofit Detail

The amount of insulation installed between the floor joists depends on the depth of floor joists. It is assumed the timber floor system is $190 \mathrm{~mm} \times 45 \mathrm{~mm}$ joists at $400 \mathrm{~mm}$ spacing. As Figure 6 shows, metal angle brace is fixed at the bottom edge of floor joist. Bulk insulation is supported by a layer of plywood. The advantage of this solution is that bulk insulation is easily fitted in and the bottom board can be tilted and removed for future check or service pipe maintenance.

\footnotetext{
${ }^{2}$ Personal communication with Steve Ellise, insulation assessor from RIGHTHOUSE Ltd, Wellington.

${ }^{3}$ Photo was taken by Professor Robert Vale from his house retrofit project.
} 


\subsubsection{Window}

Windows offer minimal thermal insulation and large area of glass can result in large heat loss. BRANZ (1995) found out that, in the Wellington region, the daily average heat loss of a window without drapes is about $1 \mathrm{KWh} / \mathrm{m}^{2} /$ day during the winter period, and well-fitted drapes can reduce by $30 \%$ the heat loss, from $1 \mathrm{KWh} / \mathrm{m}^{2} /$ day to $0.7 \mathrm{KWh} / \mathrm{m}^{2} /$ day.

In the common cases, at night time windows have often been supplied with a temporary layer of insulation in the form of curtains, which are used as to retain heat in the house and also act as a barrier to reduce radiation heat loss and air infiltration.

Windows and other glazed areas allow sunlight and fresh air to get into buildings, but they also cause heat loss.

Heat loss through windows and other glazing areas can be a significant part of total heat loss for a well insulated house. After walls, floor and roof of a lightweight house are insulated, the windows should also need upgrading alongside the rest of the building fabric, otherwise they will become very weak areas in terms of heat loss.

Although upgrading of windows is difficult, because it is hard for them to be insulated sufficiently to make them as effective as wall or roof, it is also important as part of the building envelope retrofit.

Also, the type of frame can affect the energy efficiency of windows. For existing houses, aluminium and timber are the most common window framing materials. Their performance in heat loss and air tightness varies. Aluminium frame needs low maintenance, but it also acts as a thermal bridge with its higher conductivity. Timber frame needs regular maintenance, and timber shrinkage can easily 
reduce airtightness. Many old model timber frame windows suffer from weak airtightness, which makes excessive amount of infiltration heat loss. Therefore, reducing air infiltration through windows will be a particularly important part for retrofitting. Draught seal strips can be a low cost solution for reducing existing windows infiltration heat loss. But the performance improvement varies, depending on the condition of existing windows and material of the seals.

Double glazing was introduced in the 2007 Housing Insulation Standard for the colder parts of New Zealand.

The main benefit of double glazing is made from the trapped air space between two glass panels. Only little heat resistance comes from the glass sheet. Typically, double glazing can reduce heat loss from $1 \mathrm{KWh} / \mathrm{m}^{2} /$ day to 0.55KWh/m²/day (BRANZ, 1995, p.3).

Further thermal performance improvement for double glazing window can be made by adopting low emissivity (Low-E) coating panes, which would reduce radiant heat transfer through the window.

Currently, there are a range of options for retrofitting double glazing (Amitrano et al, 2006) including:

a) Magnetic framed acrylic windows to add to the inside of aluminium frames

b) Plastic film - taped and heat-shrunk to the inside of windows

c) Frames with acrylic glazing screwed to the outside of existing window frames.

This study chose Low-E double glazing window with sufficient draught control for testing. Cost effectiveness of double glazing, magnetic framed acrylic, and draught strip will be given in the later chapter. 


\subsection{Ventilation and air infiltration}

Ventilation is essential for indoor air quality and normally it is not a major consideration in house retrofit. Currently, New Zealand house ventilation is either too much or too little in most homes. New housing shows a trend of more airtightness in construction due to the usage of sheet material internal linings and accurately manufactured building components (Bassett, 1992, p.2). Achieving proper ventilation is as important in achieving healthy homes as insulation.

Air infiltration occurs around doors and windows and through joints between building elements. An open fireplace can be another big item causing air infiltration and may allow a heat loss of $1.5 \mathrm{KW}$ (BRANZ, 1995).

Air infiltration is both an energy efficiency and an indoor air quality issue. Although airtightness and ventilation can be conflicting factors to achieve energy efficiency and indoor air quality, the rule of thumb is to make the building as air-tight as possible in terms of the building junctions, internal lining and opening details, so as to avoid unwanted infiltration of cold air, and then to deliberately ventilate as needed.

Air infiltration is another primary item that causes heat loss. This happens in the four basic building envelope elements (roof, wall, windows and floor). For a well insulated house, air infiltration heat loss can be larger than that from any of the four building elements. On the other hand, ventilation helps improve indoor air quality by diluting a wide range of indoor contaminants. In this point, a building should keep a reasonable level of ventilation. NZS4303 provides a guide of the required ventilation for different type of buildings. For residential buildings, this 
standard requires a house wide average ventilation rate of $0.5 \mathrm{ACH}$ as background level.

Therefore, the rate of $0.5 \mathrm{ACH}$ is used in this thesis as the home air infiltration retrofit target level.

Gaps around doors and windows can be sealed at very little expense. A wide range of draught-stripping materials for doors and windows is available on the market.

Once a reasonable level of insulation is installed in the building fabric, air infiltration becomes the largest element of heat loss. However, a certain rate of ventilation is necessary to provide air for the occupants living in the building.

Draught sealing materials are available for retrofitting to openings around doors and windows, where most of the air leaks in a house occur. Airtightness is also dependent on construction and age.

Bassett (1992) pointed out that simple construction houses are more airtight than larger and more complicated ones.

The airtightness character of houses can be measured with a blower door test. The airtightness result is expressed as volume air change per hour (ACH). It is normally the measurement of the air leakage rate at an international standard pressure difference of $50 \mathrm{~Pa}$. Bassett (1996) estimated that air leakage rates measured by a blower door test are typically around 20 times the basic infiltration rate. Normally for a residential house, there are two major sources of pressure that cause air to leak: wind pressure and stack pressure.

Bassett (1996) indicates that interior lining has more control over building airtightness than external cladding. 
Occupied rooms require from $0.5 \mathrm{ACH}$ to $1 \mathrm{ACH}$ to provide fresh air and remove moisture (BRANZ, 1995, p.2). Too little ventilation will result in condensation problems, but too much ventilation will result in much heat loss.

New Zealand standard (NZS 4218:2009) recommends that minimum infiltration shall be 0.5 air change per hour for housing.

Bassett $(2001$, p.7) provides base level average infiltration rates for four building classifications:

\begin{tabular}{|c|c|l|}
\hline \multicolumn{2}{|c|}{ Basic Airtightness } & \multicolumn{1}{c|}{ Typical Examples } \\
\hline Draughty: & $0.9 \mathrm{ac} / \mathrm{h}$ & Pre-1960, strip lining, strip flooring, timber window \\
\hline Leaky: & $0.7 \mathrm{ac} / \mathrm{h}$ & $\begin{array}{l}\text { Post 1960, complex shape and with unsealed } \\
\text { windows. }\end{array}$ \\
\hline Average: & $0.50 \mathrm{ac} / \mathrm{h}$ & $\begin{array}{l}\text { Post } 1960 \text { houses of larger simple designs with } \\
\text { airtight joinery. }\end{array}$ \\
\hline Airtight: & $0.25 \mathrm{ac} / \mathrm{h}$ & $\begin{array}{l}\text { Post } 1960 \text { houses with a simple rectangular single } \\
\text { story floor plan of less than } 120 \mathrm{~m} 2 \text { and airtight } \\
\text { joinery (windows with airtight seals). }\end{array}$ \\
\hline
\end{tabular}

Table 9: Base Level Average Infiltration Rates

(Source: Basset, 2001, p.7)

Apart from the figures above, to estimate house air infiltration rate, some other factors need to be considered, such as location, site exposure, fireplace opening, etc. For the Wellington region, the regional correction factor is 1.3 (Basset, 2001, p.9). Therefore, 1.2 ACH $(0.9 \mathrm{ACH} \times 1.3$ correction factor $=1.2$ $\mathrm{ACH}$ ) can be assumed for the start level air infiltration rate of a typical old house in Wellington,

\subsection{Retrofit package}

Generally, there are two potential ways for creating a retrofit package (SavilleSmith, 2008, p.5). One is a tailor-made retrofit solution. Retrofit decisions can be made for each building element (i.e. cladding, ceiling, window, etc.) and heating system by detailed inspection and assessment for each particular 
house. The drawback of this method is that it is time consuming with high labour cost. Another approach is to apply a general retrofit work scheme and work out the retrofit features and cost. This is a general retrofit solution package, which is based on house physical characteristics. The disadvantage is that a general retrofit package may not be suitable for each house due to the house variety.

\subsubsection{Government house retrofit program}

The main retrofit programme recently operating in New Zealand involves Housing New Zealand and EECA who carry out retrofits on about 5500 houses per year (Storey et al, 2004, p.10). This programme supports house owners to install insulation for ceiling and under floor with government funding. Also, a clean and energy efficient heating system is currently included in the package. The sustainability related retrofitting that occurs in New Zealand is actually related to energy saving or improving comfort levels in homes. Most of the energy saving potential of such retrofit schemes is taken up by owners with accepting higher comfort levels.

In June 2009, the New Zealand government announced a new Heatsmart programme, which was aimed to insulate 180,000 homes over four years. But a survey shows demand could be much higher than that. It showed some 280,000 homeowners intend to apply - 100,000 more than the government has planned for (TVNZ, 2009). This scheme provides government grants of up to $\$ 1300$ or a third of the cost of insulation and a $\$ 500$ grant for clean heaters. Loans would be available for the remaining cost. Starting on July 12009 , this retrofit package is run by EECA (the Energy Efficiency and Conservation Authority). 


\section{Thermal Simulation of Building Envelope Retrofit}

The previous section investigated existing house insulation and heating by theoretical background study. To examine the differences between building fabric retrofit solutions in practice, the method of thermal simulation study and analysis was determined for the further testing.

In this chapter, firstly a base building model is defined. Secondly, to have some initial concepts of the proportion of heat loss made by building elements and insulation retrofit target, heat loss analysis is given. Lastly, detailed house model simulation method is introduced.

\subsection{Base building model}

For this study, the National Modal House was selected as the house model for the retrofit test. This house model was published in 1997 with detailed descriptions. The original idea of the Modal house was developed for building cost estimating purposes (New Zealand Institute of Valuers, 1997, p.5). This building mode is believed to represent the typical floor layout and construction characteristics of some existing houses.

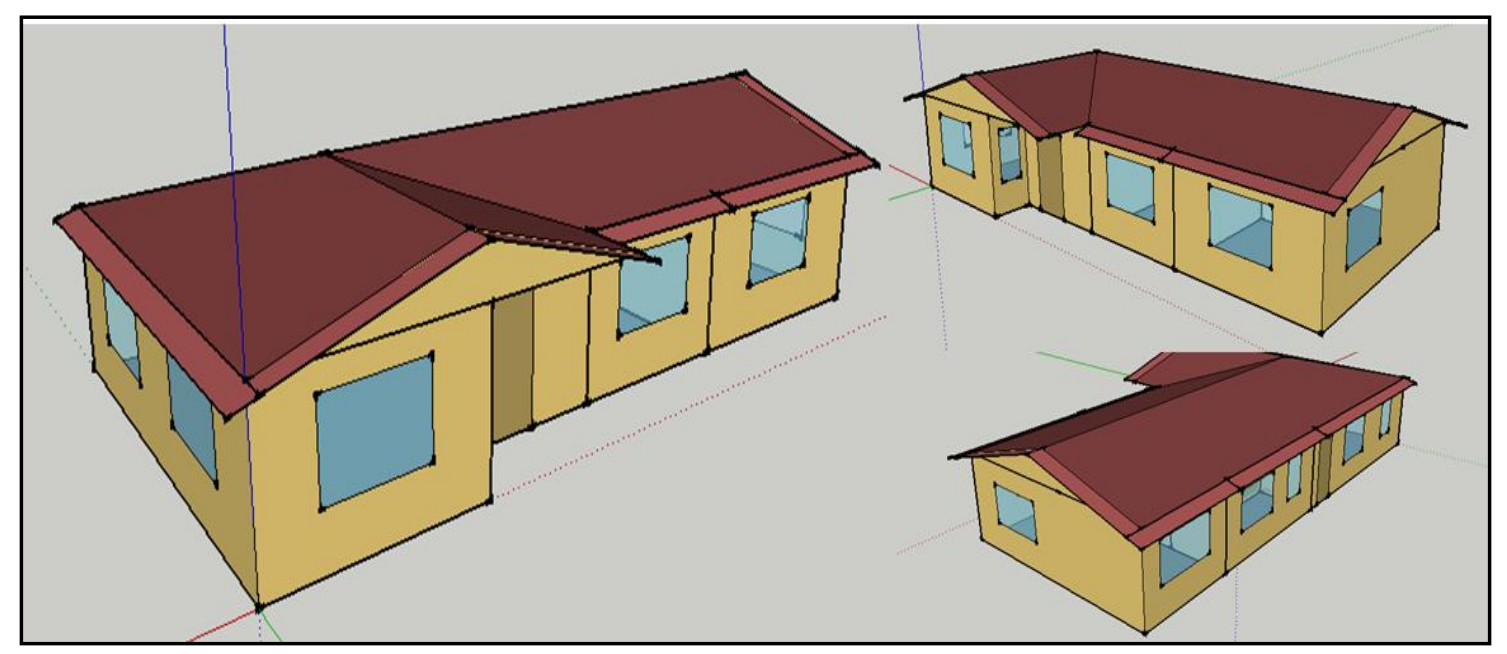

Figure 7: The National Modal House 3d Perspective 


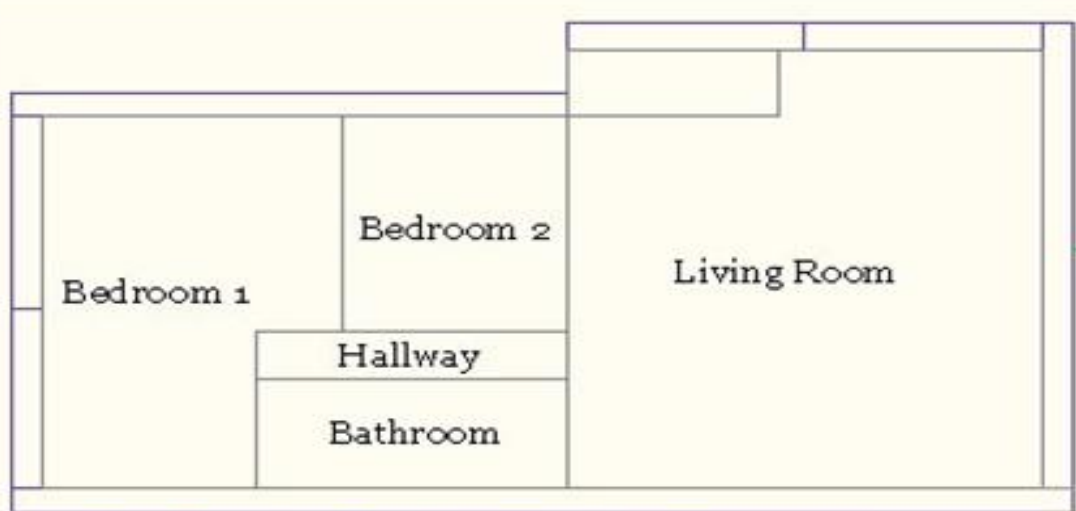

Bullding - The National Modal House

Figure 8: Thermal Simulation Zones Diagram

As this $100 \mathrm{~m}^{2}$ house contained three bedrooms, the internal wall between bedroom 1 and bedroom 3 was removed for the simulation in order to treat these two rooms as one thermal zone. This building has three bedrooms, one hallway, one bathroom, and one living room, giving a total floor area of $100 \mathrm{~m}^{2}$. For the purposes of thermal modelling, each room is regarded as a single thermal zone. Including the attic there are a total of 6 thermal zones. The floor plan and elevation of this house model can be found in Appendix $B$.

The construction and material of the defined typical building from the previous chapter were applied for the above three dimensional model. The specification of applied construction and material is given is the tables below:

\begin{tabular}{|c|c|c|}
\hline 1. Original house construction details; UNINSULATED \\
\hline Exterior wall & Window & Floor \\
\hline Weatherboards & $3 \mathrm{~mm}$ single pane & 200mm floor joist \\
\hline $100 \mathrm{~mm}$ timber stud & & Particle Board \\
\hline $10 \mathrm{~mm}$ GIB & & Carpet \\
\hline Ceiling & Roof & Interior Wall \\
\hline $35 \mathrm{~mm}$ Ceiling batten & Long-run Steel & $10 \mathrm{~mm}$ GIB \\
\hline $10 \mathrm{~mm}$ GIB & Timber truss & $100 \mathrm{~mm}$ timber stud \\
\hline & & $10 \mathrm{~mm}$ GIB \\
\hline
\end{tabular}

Table 10: Original House Construction Details 
Thermal Simulation of Building Envelope Retrofit

\begin{tabular}{|c|c|c|}
\hline 2. Proposed optimum package; Full INSULATED \\
\hline Exterior wall & Window & Floor \\
\hline Weatherboards & Double panes & 200mm. R4.6 insulation \\
\hline $100 \mathrm{~mm}$ R2.4 Insulation & Low emissivity & $200 \mathrm{~mm}$ floor joist \\
\hline $100 \mathrm{~mm}$ timber stud & & Particle Board \\
\hline $10 \mathrm{~mm}$ GIB & & Carpet \\
\hline Ceiling & Roof & Interior Wall \\
\hline $200 \mathrm{~mm}$. R4.6 insulation & Long-run Steel & $10 \mathrm{~mm}$ GIB \\
\hline $35 \mathrm{~mm}$ Ceiling batten & Timber truss & $100 \mathrm{~mm}$ timber stud \\
\hline $10 \mathrm{~mm}$ GIB & & $10 \mathrm{~mm}$ GIB \\
\hline
\end{tabular}

Table 11: Proposed Optimum Retrofit Package Details

It should be noted that the proposed optimum insulation level was chosen with the consideration of limited fit-in space for insulation materials. The rule of thumb applied here is to maximize the thickness of insulation material wherever it can be fitted into the building elements (roof, wall, underfloor).

\subsection{House heat loss analysis}

Heat losses vary from house to house depending on house size, insulation level, air tightness and orientation. The proportion of heat loss between different building elements varies due to the difference of construction and material adoption for each. In a pre 1978, uninsulated, timber house, two thirds of heat is lost through the ceiling and exterior walls (Department of Building and Housing, 2008 , p.4). It is commonly accepted that most heat is lost through ceiling and roof, and these should be the top priority for insulation retrofit.

The BRANZ house Insulation guide gives a heat loss comparison of insulated and uninsulated houses as below. 
Thermal Simulation of Building Envelope Retrofit

\begin{tabular}{|c|c|c|}
\hline \multicolumn{2}{|c|}{ Building Elements Heat Loss } \\
\hline Heat Loss Elements & Uninsulated House & $\begin{array}{c}\text { Pre-2007 Levels } \\
\text { Insulated House }\end{array}$ \\
\hline Roof & $30-35 \%$ & $13-14 \%$ \\
\hline Walls & $18-25 \%$ & $11-13 \%$ \\
\hline Windows & $21-31 \%$ & $42-45 \%$ \\
\hline Floor & $12-14 \%$ & $12-15 \%$ \\
\hline Air Leakage & $6-9 \%$ & $10-17 \%$ \\
\hline
\end{tabular}

Table 12: House Heat Loss Breakdown by Different Elements

(Source: House Insulation Guide. Tims, 2007, p.10)

The above table shows how the relative heat losses between different building elements have changed following the requirement to insulate under the Building Code. As more insulation is installed for roof, wall, and floor, the proportion of heat loss through windows and air infiltration increases. This also showed that windows become the most important building retrofit target for reducing heat loss (42-45\%) after a house is applied with pre-2007 building code level insulation.

\subsubsection{House Model heat Loss Calculation}

This section will use the defined house model and assumptions and calculate heat loss for each of the building elements. The results will give some initial concept of the proportion of heat loss made by building elements and the relationship between each of them.

BRANZ ALF3, the 'Annual Loss Factor' Method gives the formula for heat loss calculation:

Heat Loss $(\mathrm{W})=$ Heat Transfer rate $\left(\mathrm{W} /{ }^{\circ} \mathrm{C}\right) \times$ Annual Loss Factor

Annual Loss Factor is given in The 'Annual Loss Factor' Method by building locations and heating schedule. 
For Wellington area, Annual Loss factor is shown as below:

\begin{tabular}{|c|c|c|c|}
\hline \multicolumn{4}{|c|}{ Morning and evening heating, 7:00am-9:00am;5:00pm-11:00pm } \\
\hline & \multicolumn{3}{|c|}{ Annual Loss Factor. } \\
\hline Heating Level & $16^{\circ} \mathrm{C}$ & $18^{\circ} \mathrm{C}$ & $20^{\circ} \mathrm{C}$ \\
\hline Wellington & 7.6 & 9.9 & 12.2 \\
\hline
\end{tabular}

Table 13: Wellington Annual Loss Factor

(Source: ALF3 Third Edition, Stoecklein and Bassett, p.3-9)

For this part of calculation, heating level of $18^{\circ} \mathrm{C}$ with intermittent heating schedule was selected. So, Annual Loss Factor is 9.9.

\begin{tabular}{|l|}
\hline Formulas used for heat loss calculation ${ }^{4}$ : \\
\hline Heat Loss of Roof $(W)=\left(\right.$ Roof area $\left./ R_{\text {Roof }}\right) \times$ Annual Loss Factor \\
\hline Heat Loss of Wall $(W)=\left(\right.$ Wall area $\left./ R_{\text {Wall }}\right) \times$ Annual Loss Factor \\
\hline Heat Loss of Window $(W)=\left(\right.$ Window area $\left./ R_{\text {Window }}\right) \times$ Annual Loss Factor \\
\hline Heat Loss of Floor $(W)=\left(\right.$ Floor area $\left./ R_{\text {Floor }}\right) \times$ Annual Loss Factor \\
\hline Heat Loss of Air Infiltration $(W)=0.33 \times A C H \times$ Volume $\times$ Annual Loss Factor \\
\hline
\end{tabular}

The result of building element heat loss will give a whole picture of how heat is transferred and develop retrofit knowledge. Two different sizes of houses were examined, $100 \mathrm{~m}^{2}$ (defined house model) and $200 \mathrm{~m}^{2}$.

Three different insulation levels are tested.

- Scenario 1: Uninsulated house with air infiltration rate of 1.2 ACH. The Rvalues of the uninsulated building elements were chosen from BRANZ House insulation Guide (Tims, 2007).

- Scenario 2: Current Building Code (Zone-2) level insulated house (NZS 4218,2009, p.20) with air infiltration rate of $1.2 \mathrm{ACH}$

\footnotetext{
${ }^{4}$ Calculation formulas referred from ALF3, The 'Annual heat loss Factor' Method
} 
- Scenario 3: Proposed insulated house with air infiltration rate of $1.2 \mathrm{ACH}$.

The insulation level was determined with the consideration of limited fit-in space of building element.

(Infiltration rate is kept the same to make clear the changes that result from insulating the building elements.)

\begin{tabular}{|c|c|c|c|}
\hline \multicolumn{4}{|c|}{ Different scenario R-values } \\
\hline & Scenario 1 & Scenario 2 & Scenario 3 \\
\hline Heat Loss Elements & No insulation & $\begin{array}{c}\text { Building Code - } \\
\text { Climate Zone 2 }\end{array}$ & $\begin{array}{c}\text { Proposed } \\
\text { Insulation Level }\end{array}$ \\
\hline ROOF & $0.38 \mathrm{~m}^{2} \mathrm{~K} / \mathrm{W}$ & $2.9 \mathrm{~m}^{2} \mathrm{~K} / \mathrm{W}$ & $4.0 \mathrm{~m}^{2} \mathrm{~K} / \mathrm{W}$ \\
\hline WALL & $0.4 \mathrm{~m}^{2} \mathrm{~K} / \mathrm{W}$ & $1.9 \mathrm{~m}^{2} \mathrm{~K} / \mathrm{W}$ & $2.2 \mathrm{~m}^{2} \mathrm{~K} / \mathrm{W}$ \\
\hline FLOOR & $0.57 \mathrm{~m}^{2} \mathrm{~K} / \mathrm{W}$ & $1.3 \mathrm{~m}^{2} \mathrm{~K} / \mathrm{W}$ & $4.60 \mathrm{~m}^{2} \mathrm{~K} / \mathrm{W}$ \\
\hline WINDOWS & $0.15 \mathrm{~m}^{2} \mathrm{~K} / \mathrm{W}$ & $0.26 \mathrm{~m}^{2} \mathrm{~K} / \mathrm{W}$ & $0.36 \mathrm{~m}^{2} \mathrm{~K} / \mathrm{W}$ \\
\hline AIR INFILTRATION & $1.2 \mathrm{ACH}$ & $1.2 \mathrm{ACH}$ & $1.2 \mathrm{ACH}$ \\
\hline
\end{tabular}

Table 14: Different Scenario R-values

${ }^{5}$ The R-values in this table is building element construction R-value, which is slightly different (normally lower) to the R-value of insulation material, due to thermal bridges. R-value for Scenario 1 and 3 were quoted from BRANZ Insulation Guide (Third Edition, 2007). R-value for Scenario 2 was quoted from NZS4219: 2009. 
The following calculations are to show the proportion of heat loss from different building elements.

\begin{tabular}{|c|c|c|c|c|c|c|c|}
\hline \multicolumn{8}{|c|}{$100 \mathrm{~m}^{2}$ House Model -The National Modal House } \\
\hline $\operatorname{AREA}\left(m^{2}\right)$ & 100 & \multicolumn{2}{|c|}{ Perimeter $(m)$} & \multicolumn{2}{|c|}{44.6} & Height $(m)$ & 2.4 \\
\hline \multicolumn{2}{|c|}{ Window $\left(m^{2}\right)$} & \multicolumn{2}{|c|}{30.09} & & & & \\
\hline \multirow{2}{*}{$\begin{array}{l}\text { Heat loss } \\
\text { element }\end{array}$} & & \multicolumn{2}{|c|}{ Scenario 1} & \multicolumn{2}{|c|}{ Scenario 2} & \multicolumn{2}{|c|}{ Scenario 3} \\
\hline & & $\begin{array}{l}\text { Heat Loss } \\
\text { (W) }\end{array}$ & $\%$ & $\begin{array}{l}\text { Heat Loss } \\
\text { (W) }\end{array}$ & $\%$ & $\begin{array}{l}\text { Heat Loss } \\
\text { (W) }\end{array}$ & $\%$ \\
\hline Roof & $100 \mathrm{~m}^{2}$ & 2605 & $28 \%$ & 341 & $9 \%$ & 215 & $8 \%$ \\
\hline Wall & $77 m^{2}$ & 1905 & $21 \%$ & 401 & $11 \%$ & 317 & $13 \%$ \\
\hline Floor & $100 \mathrm{~m}^{2}$ & 1737 & $19 \%$ & 762 & $21 \%$ & 215 & $8 \%$ \\
\hline Windows & $30 m^{2}$ & 1986 & $22 \%$ & 1146 & $32 \%$ & 834 & $33 \%$ \\
\hline $\begin{array}{c}\text { Air } \\
\text { infiltration }\end{array}$ & $240 \mathrm{~m}^{3}$ & 950 & $10 \%$ & 950 & $26 \%$ & 950 & $38 \%$ \\
\hline \multicolumn{2}{|c|}{ TOTAL } & 9183 & $100 \%$ & 3600 & $100 \%$ & 2532 & $100 \%$ \\
\hline \multicolumn{8}{|c|}{ Heat Loss percentage by Element } \\
\hline \multirow{2}{*}{$20 \%$} & $\%$ & $21 \%$ & & $21 \%$ & $\begin{array}{l}32 \% 33 \\
\%\end{array}$ & $26 \%$ & \\
\hline & $9 \% 8 \%$ & $11 \% 13 \%$ & & $8 \%$ & & $10 \%$ & \\
\hline 40 & ROOF & $\begin{array}{c}\text { WALL } \\
\text { Scenario } 1\end{array}$ & $\begin{array}{r}F \\
\text { Scena }\end{array}$ & - Sce & $\begin{array}{l}\text { INDOWS } \\
\text { rio } 3\end{array}$ & INFILTRA & \\
\hline \multirow{4}{*}{ Scenario 1} & & 2000 & 4000 & 6000 & \multirow{2}{*}{\multicolumn{3}{|c|}{9183}} \\
\hline & & & & & & & \\
\hline & & & \multicolumn{2}{|l|}{3600} & \multirow{2}{*}{\multicolumn{3}{|c|}{ Total Heat Loss (W) }} \\
\hline & & 2532 & & & & & \\
\hline
\end{tabular}

Table 15: The Modal House Heat Loss Calculation

The air infiltration heat loss for the three scenarios is calculated with the same ventilation rate of $1.2 \mathrm{ACH}$.

The total heat loss reduced by $72 \%$, (from $9183 \mathrm{~W}$ to $2532 \mathrm{~W}$ ), by applying extra insulation. The percentage of air infiltration heat loss increased from $10 \%$ to $38 \%$ 
and acts as a dominant part of total heat loss in the well insulated house. Another remarkable heat loss reduction was discovered from windows retrofit. Compare to the uninsulated house, $840 \mathrm{~W}$ (from 1986 to $1146 \mathrm{~W}$ ) or $42.3 \%$ heat loss was saved by installing current building code level window insulation. A further $58 \%$ (from $1986 \mathrm{~W}$ to $834 \mathrm{~W}$ ) heat loss reduction was achieved after the proposed higher level window insulation was applied.

A further heat loss calculation of a $200 \mathrm{~m}^{2}$ house was made. The building model was assumed to be a rectangular shape with the proposed dimensions. The result is given below: 
Thermal Simulation of Building Envelope Retrofit

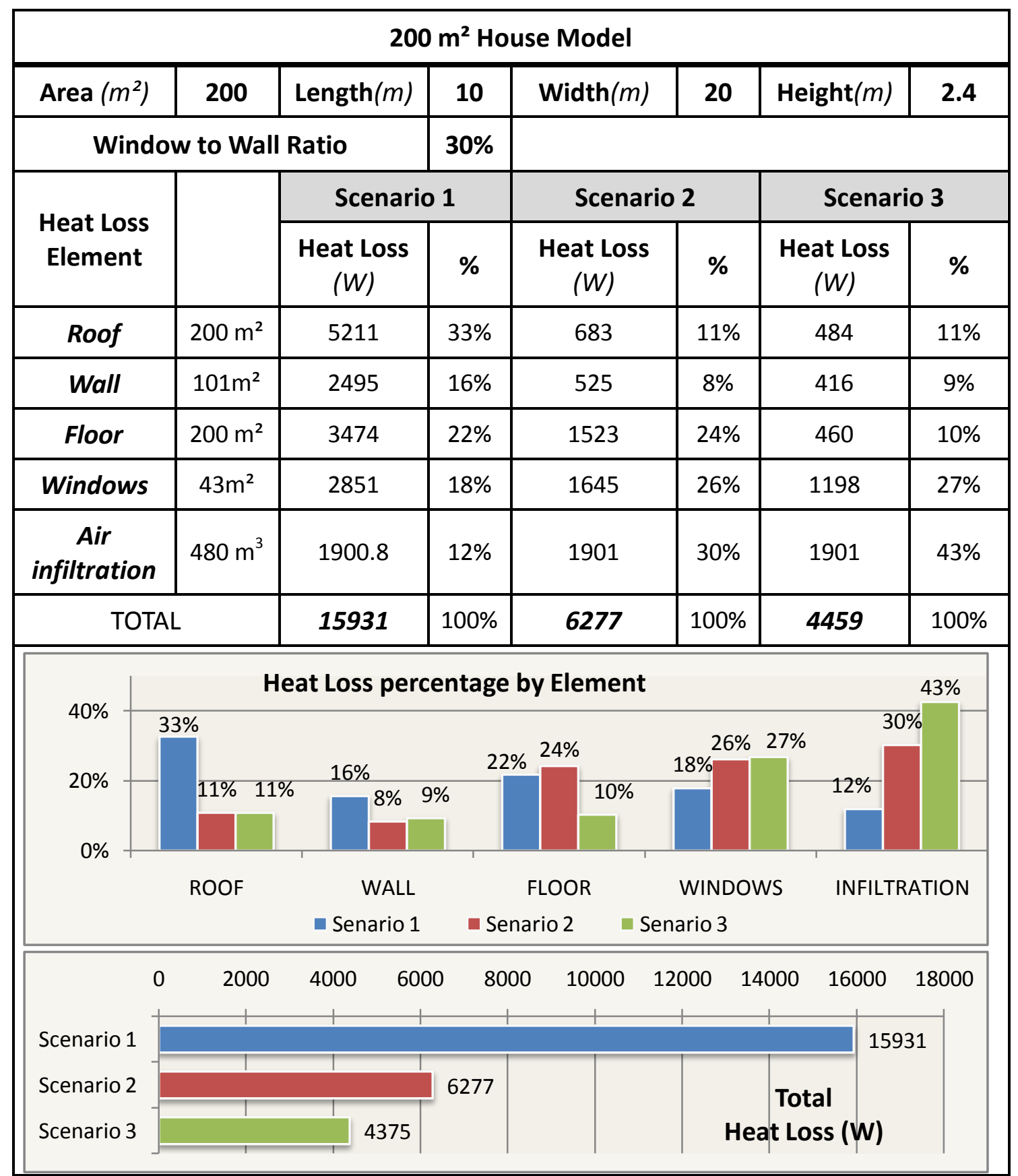

Table 16: $200 \mathrm{~m}^{2}$ House Heat Loss Calculation.

The $200 \mathrm{~m}^{2}$ house heat loss calculation result followed a similar pattern as the $100 \mathrm{~m}^{2}$ National Modal house. The lumped R-values of the two houses are quite close with each scenario. Same percent of heat loss reduction $(72 \%$, from $19531 \mathrm{~W}$ to $4459 \mathrm{~W}$ ) was achieved by the above different house sizes.

From the simple heat loss calculations, it can be seen the following findings. Windows are still the largest heat loss part of building envelope, even when 
double glazing is used. Reason of this is that the R-Value of double glazing windows is far below other building elements. Even the use of double glazing with low-emissivity coating gives an R-value of only $0.36 \mathrm{~m}^{2} \mathrm{~K} / \mathrm{W}$, which is similar to the uninsulated roof of Scenario 1.

Building code required R-Value for floor is R1.3 for climate zone 2. However, improvement can be made by using bulk insulation material in the floor instead of foil. The use of bulk insulation in the floor reduces total floor heat loss from $762 \mathrm{~W}$ in the Scenario 2 Building Code house to only 215W, a significant reduction (based on $100 \mathrm{~m}^{2}$ house).

Heat loss from wall did not show a big change between Building Code level and optimum level insulation. Roof heat loss was the smallest, around 9\%. Roof heat loss (using the $100 \mathrm{~m}^{2}$ house as an example) changes from being $28 \%$ of the total in the uninsulated house of Scenario 1 , to only $8 \%$ of the total in the fully insulated house of Scenario 3.

Air infiltration heat loss became the dominant section, about $40 \%$ of the total, after full insulation for the above two house models. This shows clearly the need to reduce uncontrolled ventilation as part of a full energy-saving retrofit approach.

\subsection{Detailed house model thermal simulation}

The method of the thermal simulation test is believed to be the most direct approach to examine a building's performance, because the data is going to be used for comparing the efficacy of different retrofit options. The simulation results are also used for comfort and energy analysis.

\subsubsection{Simulation tool, EnergyPlus}

Simulation tools were also carefully explored for this research. There are many 
kinds of building energy simulation programs available, e.g., ALF3, HOMES, SUNREL, ECOTECT and EnergyPlus. Compared with other thermal simulation programs, EnergyPlus has more advanced features than others as below:

- EnergyPlus can import building geometry file, which is created by other program, such as SKETCHUP and DESIGNBUILDER.

- EnergyPlus can complete more accurate simulations for convection models, more realistically specified devices, and more specific input.

- EnergyPlus can model building in greater detail and provide mean radiation temperature (MRT) simulation.

- EnergyPlus variables are more easily acquired as results can be kept to exactly what is demanded. The relative variables are available in the RDD file after each simulation.

EnergyPlus has been adopted as the official building simulation program of the United States Department of Energy. It is a worldwide accepted simulation tool in the building energy analysis community. The EnergyPlus program was created based on the combination of two programs BLAST and DOE-2 with some new capabilities (Ramos and Ghisi, 2010, p.4). EnergyPlus simulates ventilation, water, heating, cooling, lighting, and other energy flows in buildings. EnergyPlus has been introduced as a tool for application on energy simulation, load calculation, building performance, simulation, energy performance, heat balance, and mass balance (Crawley et al, 2001, p.320). The integrated systematic calculation provides more accurate space temperature prediction, occupant comfort and occupant health calculations. Integrated simulation also allows users to evaluate realistic system controls, moisture adsorption and 
desorption in building elements, radiant heating and cooling systems, and interzone air flow (Crawley et al, 2005, p.4).

EnergyPlus has been chosen as the simulation tool to generate the data used in this study to estimate heating energy consumption based on different heating schedules.

Simulation quality control was made by using materials template. EnergyPlus is a simulation engine with input and output of text files. A set of building simulation material template files were created for this research. Each of the template files consists of the thermal property data for common materials, which were collected from the different selected databases of this research. Different data sources were input to the building models by using the materials templates before each simulation test. This made the data accurate and also ensured a higher level of quality control. 'EnergyPlus' audit files were also checked regularly for errors.

\subsubsection{Simulation location and weather file}

This research will focus on the study of housing stock in the Wellington region. In New Zealand, Wellington is the third largest city with a considerable proportion of the population. The population of this area is predicted to grow consistently and slowly. This means a high proportion of people of Wellington will live in pre-1978 houses for the reason of slow house production (Amitrano et al, 2006, p.54).

The Wellington weather file is used to set a baseline for building simulation in New Zealand.

\subsubsection{Base building model energy use}

Since Wellington was chosen as the house location, thus this study adopted 
Wellington household average energy data from the HEEP study as building model energy use level.

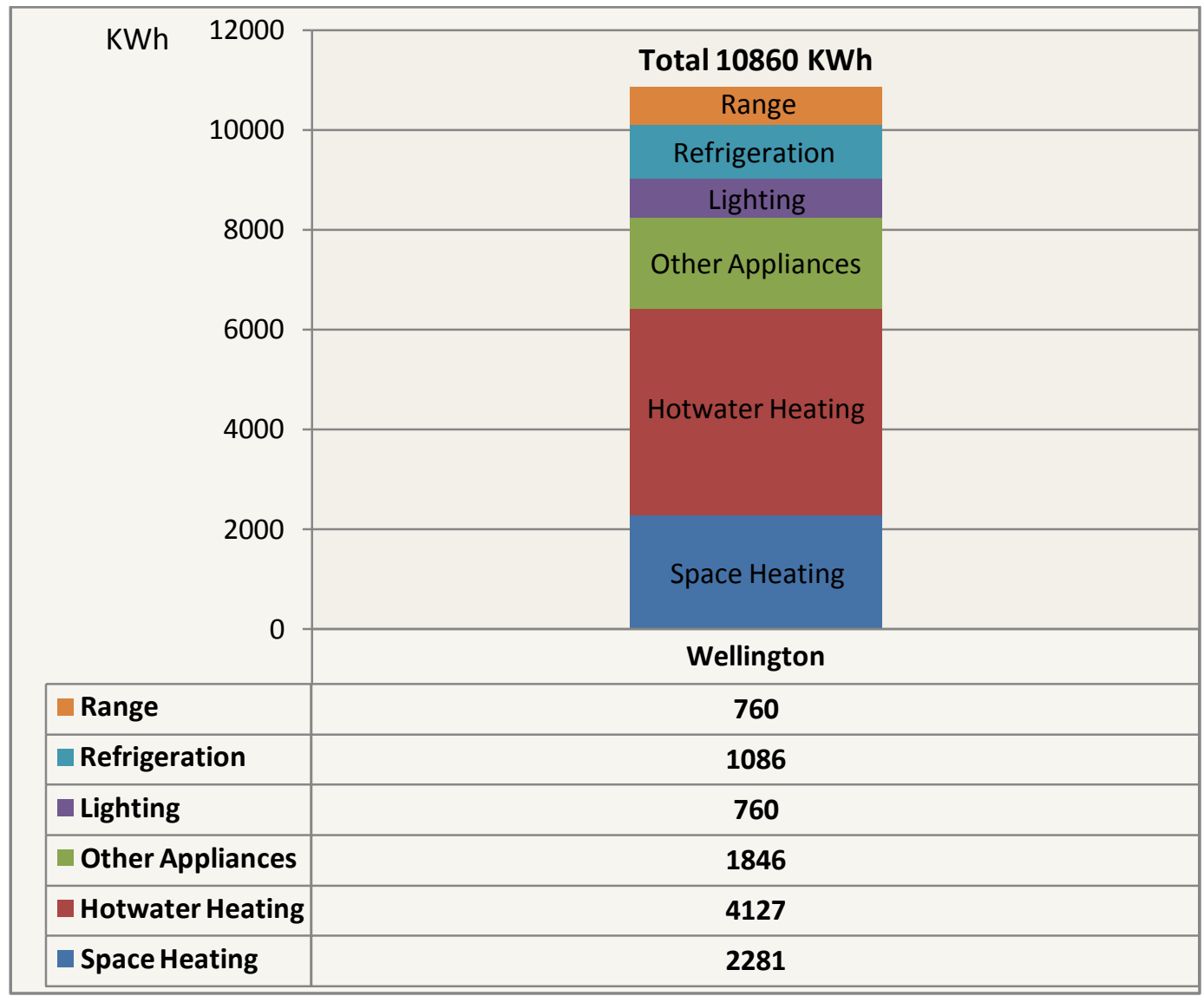

Figure 9: Wellington Average Household Energy End Use

Source: (HEEP, year 10 report, Isaacs et al, 2006, p16-17)

Figure 9 presents household energy end use breakdown. This has been used as base level energy consumption. In the next few chapters, retrofitted house model energy results will be compared with this base level.

\subsubsection{Modelling assumptions}

For the building simulation model, the following modeling assumptions were applied.

- Orientation: Due north. This orientation is considered the best in southern hemisphere for solar heat gain.

- House model geometry: the National Modal House. 
- Construction and material: the typical house defined in previous chapter.

- Occupants: 3 people, internal gain from occupants with $3 \mathrm{~W} / \mathrm{m}^{2}$ for floor area over $50 \mathrm{~m}^{2}$ with the following occupancy schedules:

\begin{tabular}{|c|c|c|c|c|c|}
\hline \multicolumn{7}{|c|}{ Occupants internal gain schedules in percentage } \\
\hline & $12 \mathrm{am}-8 \mathrm{am}$ & $8 \mathrm{am}-11 \mathrm{am}$ & $11 \mathrm{am}-6 \mathrm{pm}$ & $6 \mathrm{pm}-10 \mathrm{pm}$ & $10 \mathrm{pm}-12 \mathrm{am}$ \\
\hline Week & $100 \%$ & $60 \%$ & $60 \%$ & $100 \%$ & $100 \%$ \\
\hline Saturday & $100 \%$ & $100 \%$ & $50 \%$ & $70 \%$ & $100 \%$ \\
\hline Sunday & $100 \%$ & $100 \%$ & $50 \%$ & $70 \%$ & $100 \%$ \\
\hline
\end{tabular}

Table 17: Occupants Internal Gain Schedules (Source: NZS 4218:2009, p.57)

- Domestic hot water internal gain contribution: It is suggested $100 \mathrm{~W}$ per building for each internal cylinder (NZS 4218:2009, p.59). In this study, it is assumed there is one cylinder for hot water.

- Space heating schedule and temperature set:

\begin{tabular}{|c|c|c|}
\hline Schedule & Heating schedule & Temperature \\
\hline No heating & -- & -- \\
\hline \multirow{2}{*}{$\begin{array}{l}\text { Intermittent house heating } \\
\text { (working couple home) }\end{array}$} & $\begin{array}{c}\text { Living room, } \\
5: 00-7: 00 \text { and } 17: 00-23: 00\end{array}$ & $18^{\circ} \mathrm{C}$ \\
\hline & Bed room, 22:00-7:00 & $16^{\circ} \mathrm{C}$ \\
\hline \multirow{2}{*}{24 hours heating } & Living room, 24 hours & $18^{\circ} \mathrm{C}$ \\
\hline & Bed room, 24 hours & $16^{\circ} \mathrm{C}$ \\
\hline
\end{tabular}

Table 18: Space Heating Schedule and Temperature Set Point

- Power density: internal gain from plug loads, $24.53 \mathrm{~W} / \mathrm{m}^{2}$ (includes appliances and lighting) with the following schedules:

\begin{tabular}{|c|c|c|c|c|}
\hline \multicolumn{5}{|c|}{ Power load in percentage } \\
\hline & $12 \mathrm{am}-8 \mathrm{am}$ & $8 \mathrm{am}-6 \mathrm{pm}$ & $6 \mathrm{pm}-10 \mathrm{pm}$ & $10 \mathrm{pm}-12 \mathrm{am}$ \\
\hline Daily & $3 \%$ & $23 \%$ & $27 \%$ & $20 \%$ \\
\hline
\end{tabular}

Table 19: Power Load Schedules

(Source: NZS 4218:2009, p.57 and 59) 
- Retrofit options:

\begin{tabular}{|c|c|c|c|c|}
\hline \multicolumn{5}{|c|}{ Retrofit insulation levels with draught control } \\
\hline & Roof & Floor & Wall & Window \\
\hline Construction & $\begin{array}{l}\text { Corrugated } \\
\text { Steel cladding } \\
\text { with timber } \\
\text { truss }\end{array}$ & $\begin{array}{l}\text { Suspended } \\
\text { timber floor }\end{array}$ & $\begin{array}{l}\text { Timber frame } \\
\text { with } \\
\text { weatherboard } \\
\text { cladding }\end{array}$ & Timber frame \\
\hline \multirow[t]{3}{*}{ Building Code } & $\begin{array}{l}\text { R2.9(Bulk } \\
\text { Insulation) }\end{array}$ & $\begin{array}{l}\text { R1.3 (Dropped } \\
\text { Foil) }\end{array}$ & $\begin{array}{l}\text { R1.9 (Bulk } \\
\text { Insulation) }\end{array}$ & $\begin{array}{l}\text { Double } \\
\text { glazing }\end{array}$ \\
\hline & \multicolumn{4}{|c|}{ Air Infiltration } \\
\hline & $1.2 \mathrm{ACH}$ & $0.9 \mathrm{ACH}$ & $1.2 \mathrm{ACH}$ & $0.9 \mathrm{ACH}$ \\
\hline \multirow[t]{3}{*}{$\begin{array}{l}\text { Optimum } \\
\text { Insulation }\end{array}$} & $\begin{array}{l}\text { R4.6(Bulk } \\
\text { Insulation) }\end{array}$ & $\begin{array}{l}\text { R4.6 (Bulk } \\
\text { insulation) }\end{array}$ & $\begin{array}{l}\text { R2.4 (Bulk } \\
\text { Insulation) }\end{array}$ & $\begin{array}{l}\text { Double } \\
\text { glazing }\end{array}$ \\
\hline & \multicolumn{4}{|c|}{ Air Infiltration } \\
\hline & $1.2 \mathrm{ACH}$ & $0.9 \mathrm{ACH}$ & $1.2 \mathrm{ACH}$ & $0.9 \mathrm{ACH}$ \\
\hline \multicolumn{5}{|r|}{$\begin{array}{l}\text { ouble glazing } \\
\frac{\text { ey would }}{\text { fing will give }} \\
\text { finally reach a }\end{array}$} \\
\hline
\end{tabular}

Table 20: Retrofit Insulation Levels with Draught Control

\subsection{Building model simulations procedure}

The thermal simulation tests analysed the following results

Thermal comfort result:

* Mean air temperature,

* Mean radiant temperature.

Space heating energy requirement result:

* Zone sensitive heating energy.

The first group of thermal simulation tests include two types of examinations:

\section{A. Retrofit element study}

Building element insulation retrofit solutions for roof, floor, wall and windows are tested and compared separately. 


\section{B. Retrofit combination study}

In practice a number of retrofit options are applied together. This tested the combined effect of different retrofit options putting them together step by step.

Table 21 gives a summary comparing the retrofit modelled with Building Code level insulation.

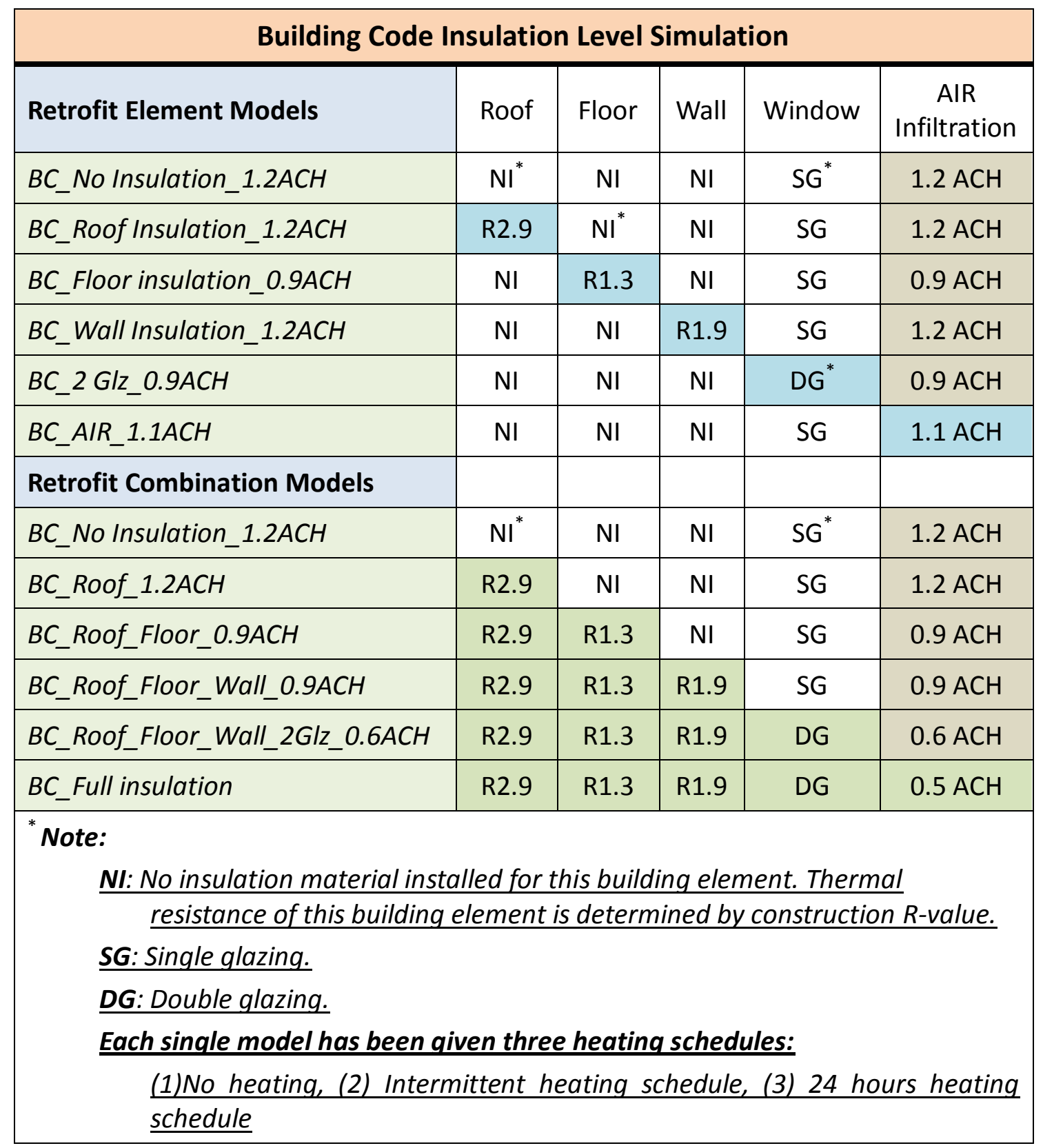

Table 21: Building Code Level Retrofit Model Details.

Table 22 below gives a summary comparing the retrofit modelled with optimum 
level insulation.

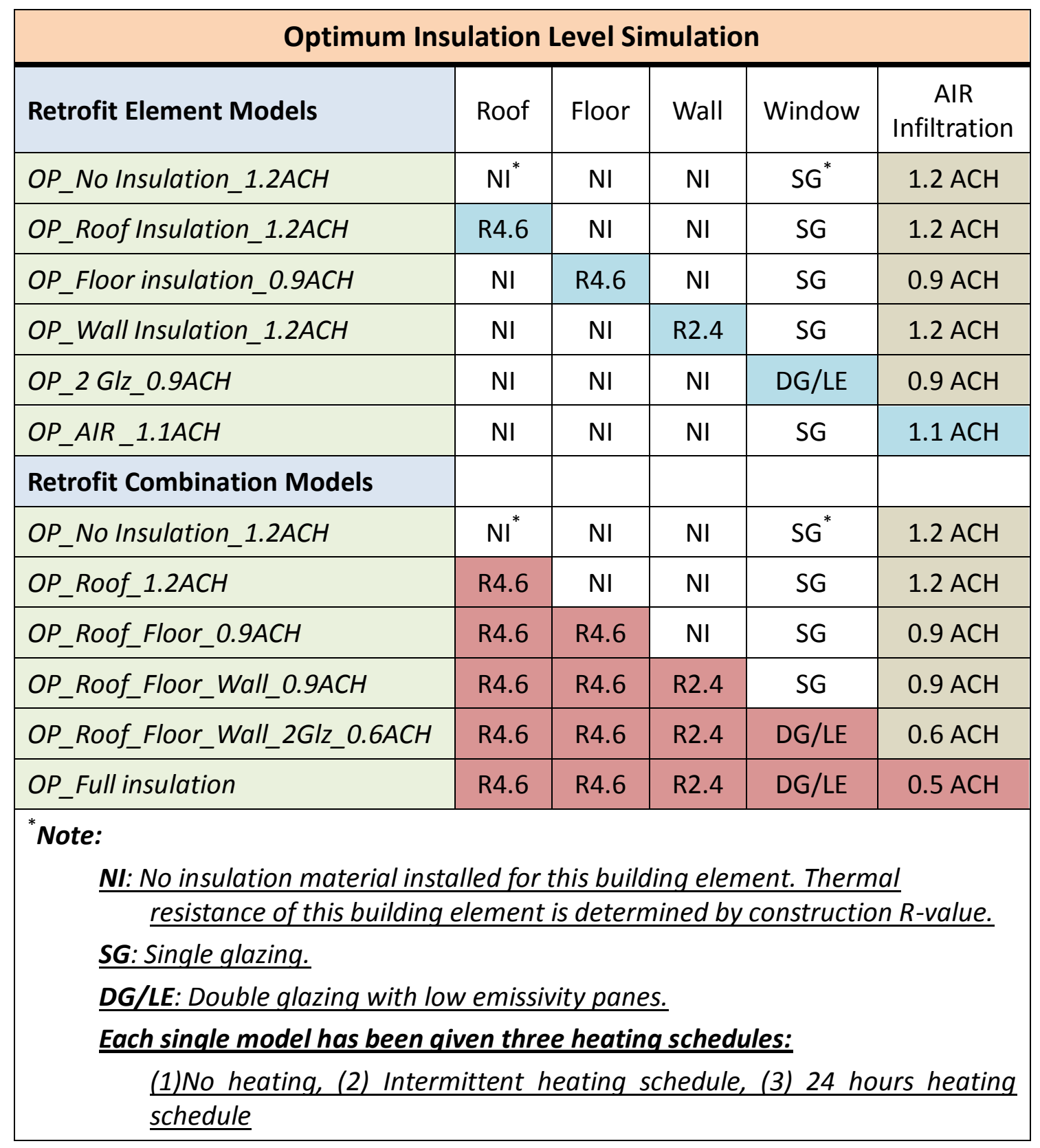

Table 22: Optimum Level Retrofit Model Details.

Similar to Building Code level simulation, optimum level simulation was carried out with the same process but different degree of insulation. 


\subsection{Results of simulations}

All of the models were simulated for each of the heating schedules and for different periods of whole year and winter months (June-August). A series of modifications were carried out with thermal models to explore the thermal performance variance of different retrofit options. These included: ceiling insulation; floor insulation; window double glazing; wall insulation; air infiltration level. Three levels of insulation were tested: No Insulation, Current Building Code, Optimum level. Each model was tested with three heating schedules: no heating, intermittent schedule, 24 hours heating. Two groups of data were collected: heating energy (living room and bedrooms) and living room temperatures, including MAT and MRT.

\begin{tabular}{|c|c|c|}
\hline & Heating Schedule & Results for analysis \\
\hline \multirow{3}{*}{$\begin{array}{c}\text { Thermal Simulation } \\
\text { Model }\end{array}$} & No Heating & \multirow{2}{*}{ MAT and MRT } \\
\cline { 2 - 2 } & Intermittent Heating schedule & \multirow{2}{*}{ Heating Energy } \\
\cline { 2 - 2 } & 24 hours heating schedule & \\
\hline
\end{tabular}

Table 23: Simulation Schedule and Analysis Data Type

\subsubsection{Space heating energy requirement result analysis}

For each single retrofitting option, the 24 hours heating schedule was applied for testing heating energy requirement. Compare to intermittent heating schedules, the 24 hour schedule makes a significant difference to total annual heating energy requirement especially for partially and non-insulated house models, as shown in Figure 10. 


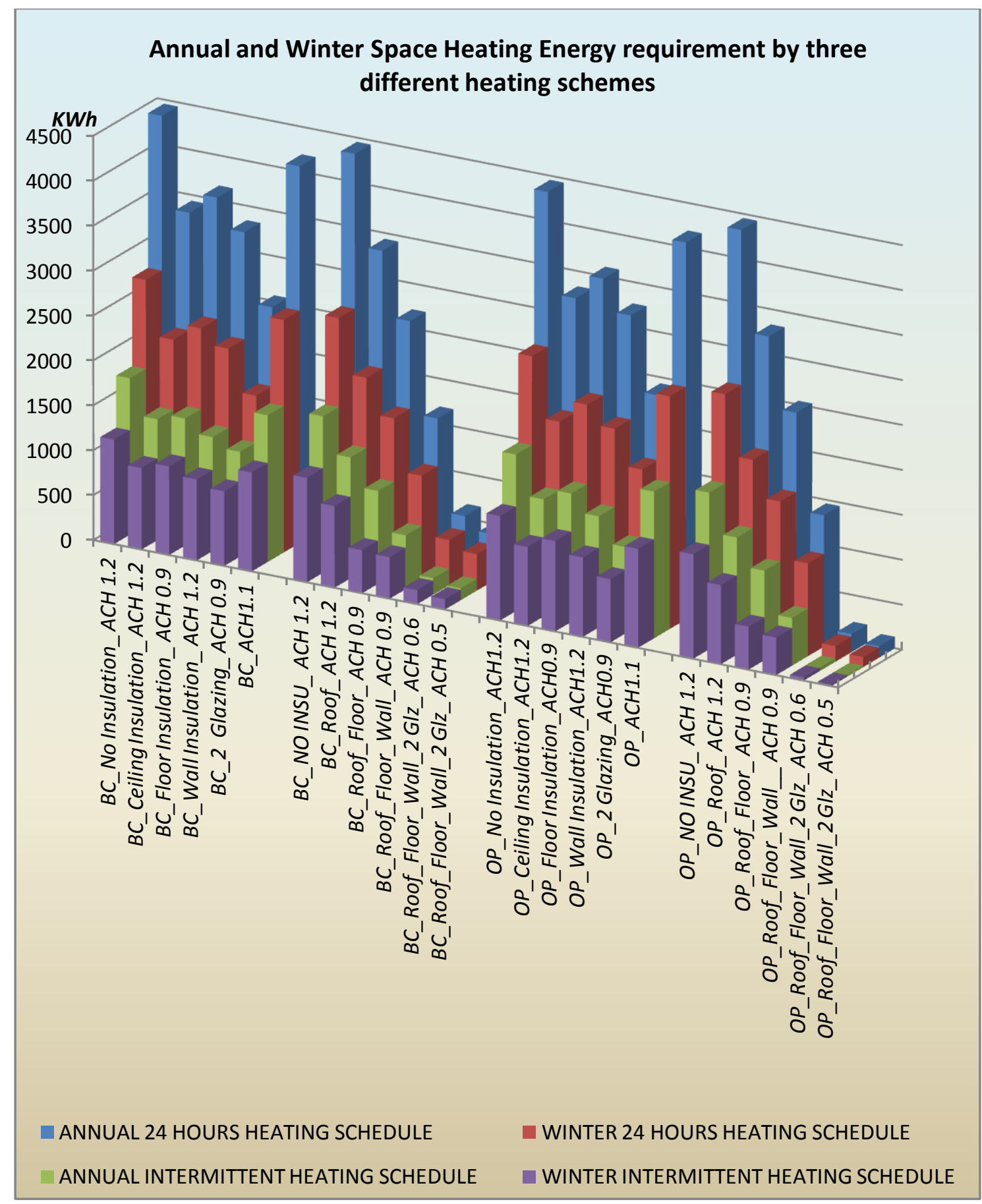

Figure 10: Annual and Winter Space Heating Energy Requirement

The energy requirements in $\mathrm{KWh}$ for annual and winter space heating are presented in Figure 10. As can be seen the optimum level house model requires less space heating energy compared with Building Code level ones for both heating schedules and both heating periods. It is significant that more heating is required for comfort over the year than is estimated by assuming that the winter 
period lasts only three months. The heating season clearly extends into autumn and spring as shown by the annual heating demand. A considerable difference was discovered when comparing the heating energy reduction of optimum level full insulation models with Building Code level insulation ones. Also, there was a relatively bigger difference between annual and winter space heating energy requirement for Building Code level insulated house models.

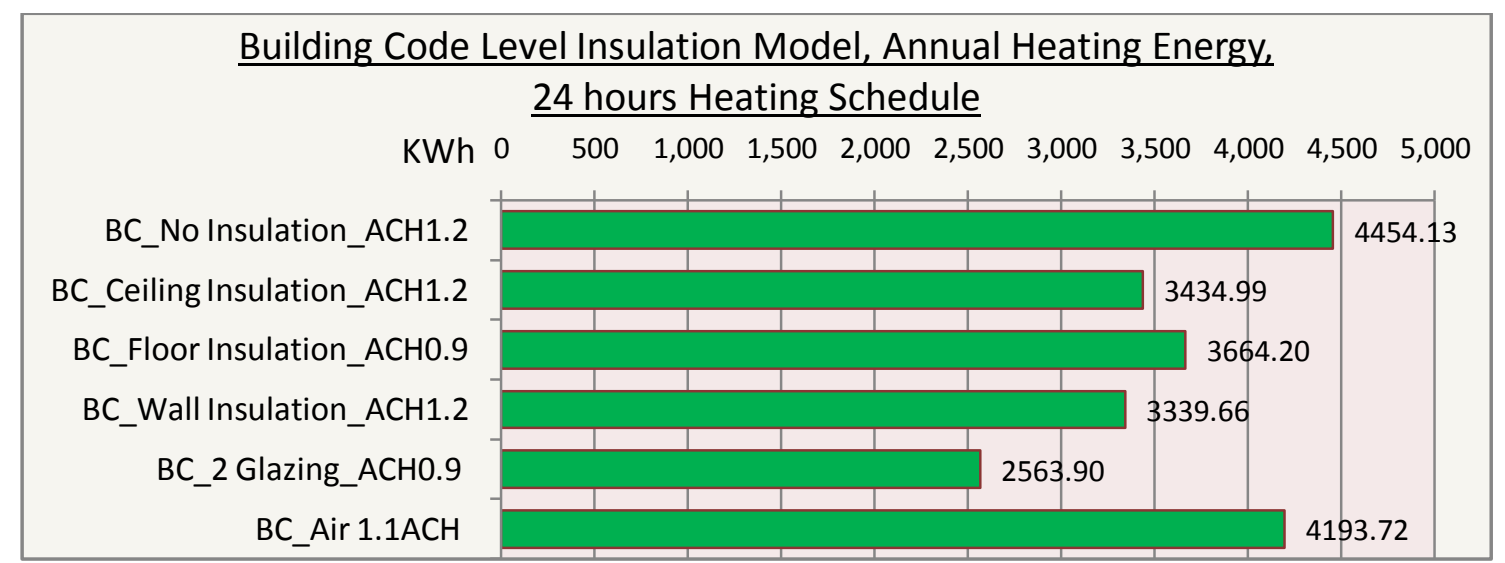

Figure 11: Building Code Level Elementary Insulation Retrofit Annual Space Heating Energy.

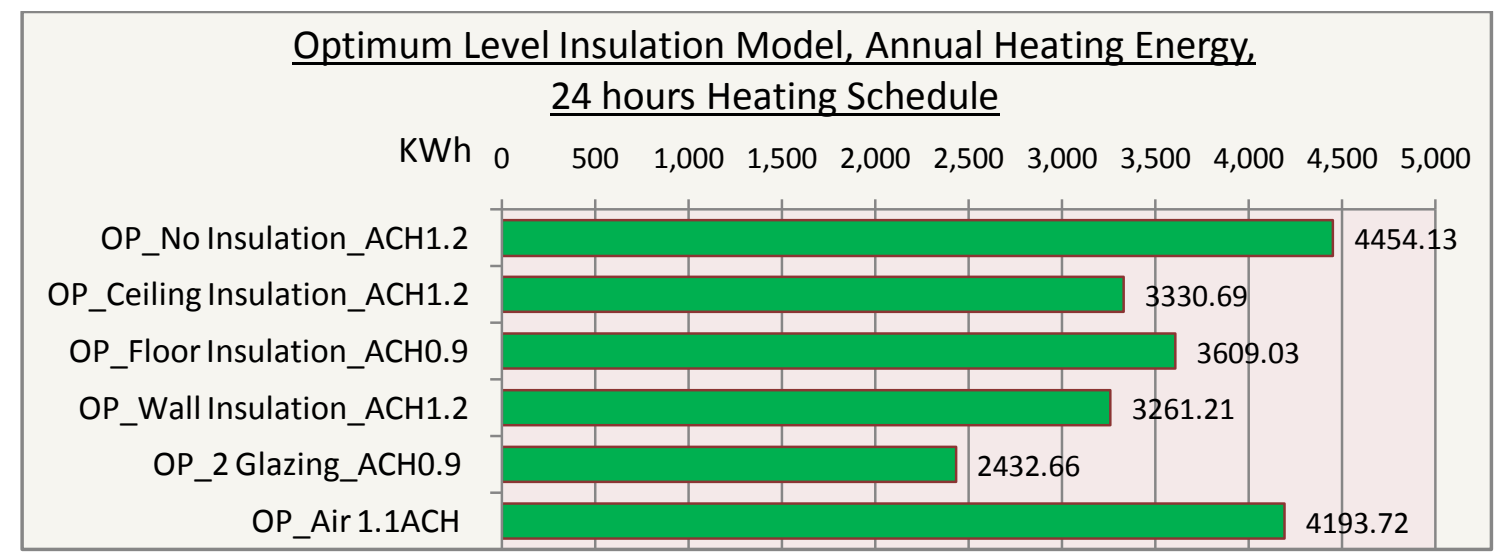

Figure 12: Optimum Level Insulation Retrofit Annual Space Heating Energy. The above two charts compare the space heating requirement of the two different levels of insulation and air infiltration retrofit element control models. For each of the building element retrofits, the charts showed a similar pattern of heating energy reduction, but the optimum level models required less (around 3\% reduction) energy overall compared with the Building Code level ones. 


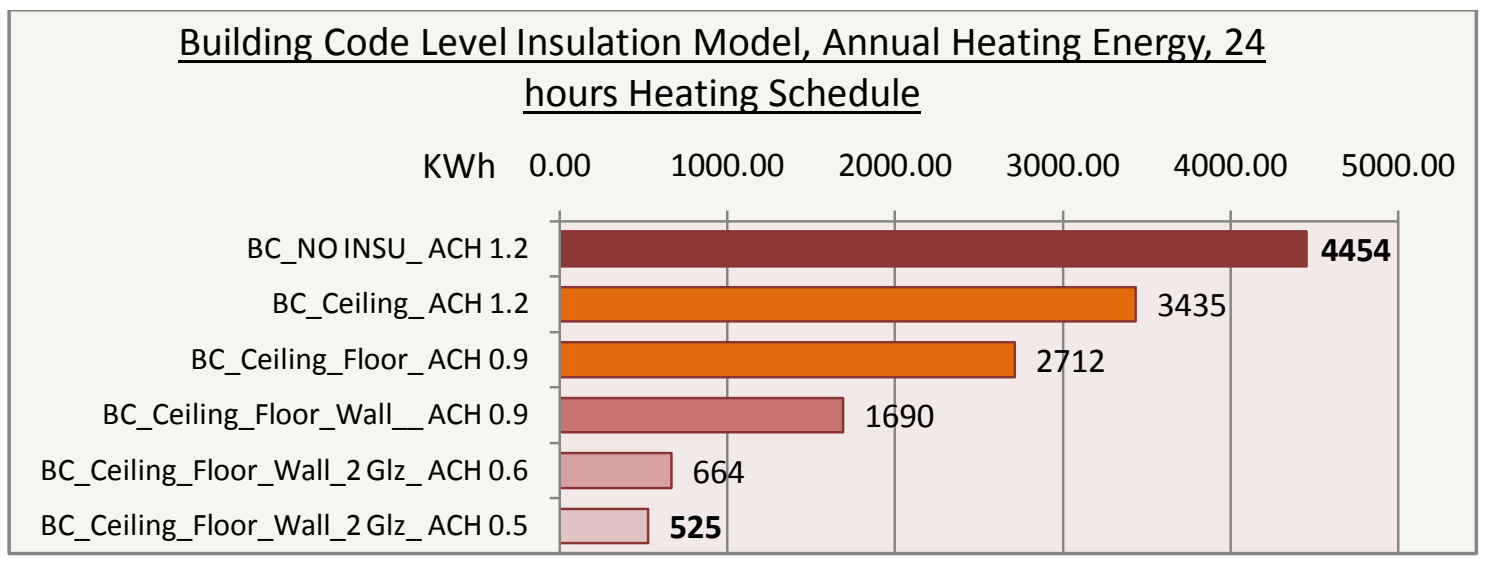

Figure 13: Building Code Level Combined Insulation Retrofit Models Annual Space Heating Energy.

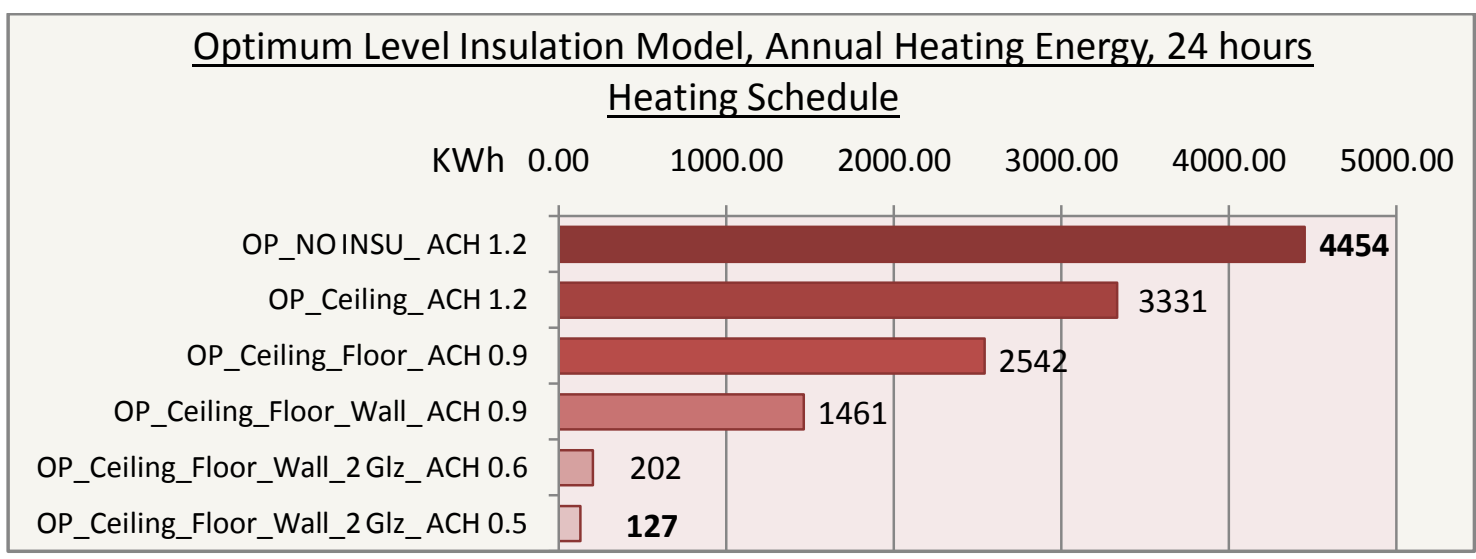

Figure 14: Optimum Level Combined Insulation Retrofit Models Annual Space Heating Energy.

The above two figures show that, for a 24 hours heating schedule, the space heating requirement dropped from $4454 \mathrm{KWh} /$ year for the no insulation house to $127 \mathrm{KWh} /$ year for the optimum level full insulation model. In Figure 13, the two orange colour bars represent the current government supported insulation retrofit program. With optimum level insulation for ceiling and floor, a further 170KWh space heating energy saving can be achieved. For the full insulated house model results as presented in Figure 14, the optimum level house model requires a quarter of the space heating as that simulated for the Building Code level model for 24 hours heating schedule. This is the consequence of the combination of higher level insulation applied to all building elements.

A large space heating reduction was observed by double glazing retrofit for both 
retrofit models. Some detailed comparisons are given as below.

\begin{tabular}{|c|c|c|}
\hline \multicolumn{3}{|c|}{$\begin{array}{l}\text { Heating Energy Comparison between Excluding and Including Double Glazing } \\
\text { Retrofit }\end{array}$} \\
\hline \multirow{3}{*}{$\begin{array}{l}\text { Excluding } \\
\text { Double } \\
\text { Glazing } \\
\text { Retrofit }\end{array}$} & BC_Ceiling_Floor_Wall_ACH0.9 & OP_Ceiling_Floor_Wall_ACHO.9 \\
\hline & 1690KWh & $1641 \mathrm{KWh}$ \\
\hline & \multicolumn{2}{|c|}{ 13.6\% Heating Energy Reduction } \\
\hline \multirow{9}{*}{$\begin{array}{l}\text { Including } \\
\text { Double } \\
\text { Glazing } \\
\text { Retrofit }\end{array}$} & BC_Ceiling_Floor_Wall_ACH0.9 & $\begin{array}{l}\text { BC_Ceiling_Floor_Wall_2GIz_ } \\
\mathrm{ACH} 0.6\end{array}$ \\
\hline & 1690KWh & $664 K W h$ \\
\hline & \multicolumn{2}{|c|}{ 60.7\% Heating Energy Reduction } \\
\hline & OP_Ceiling_Floor_Wall_ACH0.9 & $\begin{array}{l}\text { OP_Ceiling_Floor_Wall_2Glz_ } \\
\text { ACH0.6 }\end{array}$ \\
\hline & $1461 \mathrm{KWh}$ & $202 K W h$ \\
\hline & \multicolumn{2}{|c|}{ 86.2\% Heating Energy Reduction } \\
\hline & $\begin{array}{l}\text { BC_Ceiling_Floor_Wall_2Glz_ } \\
\mathrm{ACH} 0.6\end{array}$ & $\begin{array}{c}\text { OP_Ceiling_Floor_Wall_2Glz_ } \\
\text { ACHO.6 }\end{array}$ \\
\hline & 664KWh & $202 \mathrm{KWh}$ \\
\hline & \multicolumn{2}{|c|}{ 69.6\% Heating Energy Reduction } \\
\hline
\end{tabular}

Table 24: Heating Energy Comparison of Double Glazing Retrofit Building element retrofit without double glazing makes $13.6 \%$ reduction of heating energy requirement. $60.7 \%$ and $86.2 \%$ of heating energy can be saved respectively for Building Code Level retrofit and Optimum Level Retrofit, when double glazing retrofit is included. Also, after double glazing retrofit is applied, Optimum Level retrofit reduced heating energy by $69.6 \%$, comparing to the one of Building Code Level retrofit.

This is because double glazing retrofit included second glazing pane retrofit which results in both an Improvement in the heat loss through glazing and air tightness improvement. The difference of the two levels of double glazing retrofit is that the optimum level uses low emissivity glazing panes.

The intermittent heating requirement results of Building Code level and optimum level insulation house models show the similar pattern as 24 hours heating 
scheme. The required heating energy for the winter period is quite close to the one of year round, when the house is heated intermittently with the proposed schedule.

The simulation results by using intermittent heating schedule can be found in Appendix C (Figure27-34).

\subsubsection{Thermal comfort assessment}

As discussed in the previous chapters, thermal comfort will be assessed with two variables: mean air temperature (MAT) and mean radiant temperature (MRT). In this study, living room winter period hourly simulated temperatures are collected. This was because winter indoor temperatures are relatively low in New Zealand houses, and this was the main target for improving thermal comfort. To investigate the relationship between different building fabric retrofit methods and indoor temperatures, 'no space heating' simulation results were analysed. 
Thermal Simulation of Building Envelope Retrofit

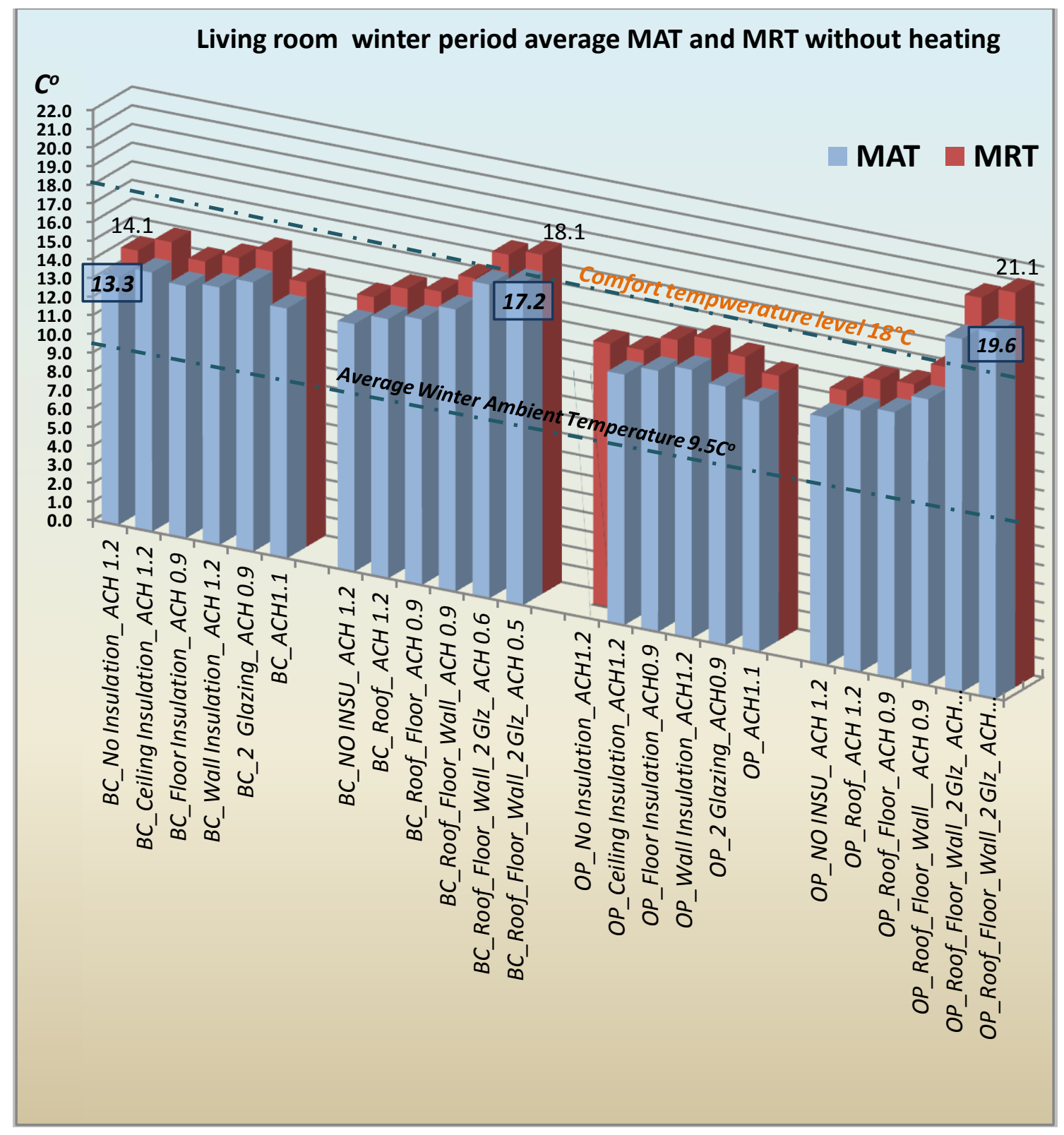

Figure 15: Living Room Winter Period Average MAT and MRT

The above figure presents the average MAT and MRT of the living room for the three months winter period. As can be seen all of the MRTs are around $1-2{ }^{\circ} \mathrm{C}$ higher than MAT. For the combined retrofit solutions, both average MAT and MRT increased steadily as a result of putting more insulation into the house model. The house model, with no insulation, single glazing and air infiltration rate of $1.2 \mathrm{ACH}$, had the lowest average temperature of $13.3^{\circ} \mathrm{C}$ for the winter period. The highest average MAT was observed at $19.6^{\circ} \mathrm{C}$ in the optimum level 
full insulated model. The average MAT of the Building Code level full insulated model achieved $17.2 \mathrm{C}^{\circ}$. The highest average MRT is $21.1^{\circ} \mathrm{C}$ achieved by the optimum level full insulation model, which is $3^{\circ} \mathrm{C}$ warmer than the Building Code level full insulation model. Optimum level full insulation retrofit has made the original no insulation model $6.3^{\circ} \mathrm{C}$ warmer in terms of MAT, and $7^{\circ} \mathrm{C}$ for MRT; similar improvements of $3.9^{\circ} \mathrm{C}$ and $4^{\circ} \mathrm{C}$ respectively were achieved with Building Code level full insulation retrofit. As mentioned in the thermal comfort chapter, HPAC indicated that for every 1F MRT decrease, air temperature needs to be raised by about $1.4 \mathrm{~F}$ to achieve similar comfort conditions (HPAC, 2010, p.1). Therefore, it can be concluded that the actual thermal comfort benefit is higher than observed mean air temperature improvement, for the reason of mean radiant temperature increase.

The HEEP project gave the results of winter living room temperature at different periods of a day:

\begin{tabular}{|c|c|c|c|c|}
\hline \multicolumn{5}{|c|}{ Mean Winter Temperatures $\left({ }^{\circ} \mathrm{C}\right)$} \\
\hline & Morning & Day & Evening & Night \\
\hline Living room & 13.5 & 15.8 & 17.8 & 14.8 \\
\hline Ambient & 7.8 & 12.0 & 9.4 & 7.6 \\
\hline
\end{tabular}

Table 25: HEEP Monitored Winter Living Room Temperatures (Source: French et al 2006, p.8).

It can be seen that living room evening mean temperature over the winter period was $17.8 \mathrm{C}^{\circ}$. The average temperature was calculated as $15.5^{\circ} \mathrm{C}$.

Both of the Building Code level and optimum level full insulated house model winter living room average temperatures are $1.6^{\circ} \mathrm{C}$ and $4.1^{\circ} \mathrm{C}$ higher than HEEP monitored temperatures, even with no heating. Again the combination of insulation retrofits can improve warmer indoor temperatures during the winter 
period.

The average winter temperatures give a broad view of thermal comfort improvement. To explore the comfort hours of this three month period, both of the collected MAT and MRT results were sorted out into two range groups: comfortable band $\left(>18 C^{\circ}\right)$ and uncomfortable band $\left(<18 C^{\circ}\right)$.

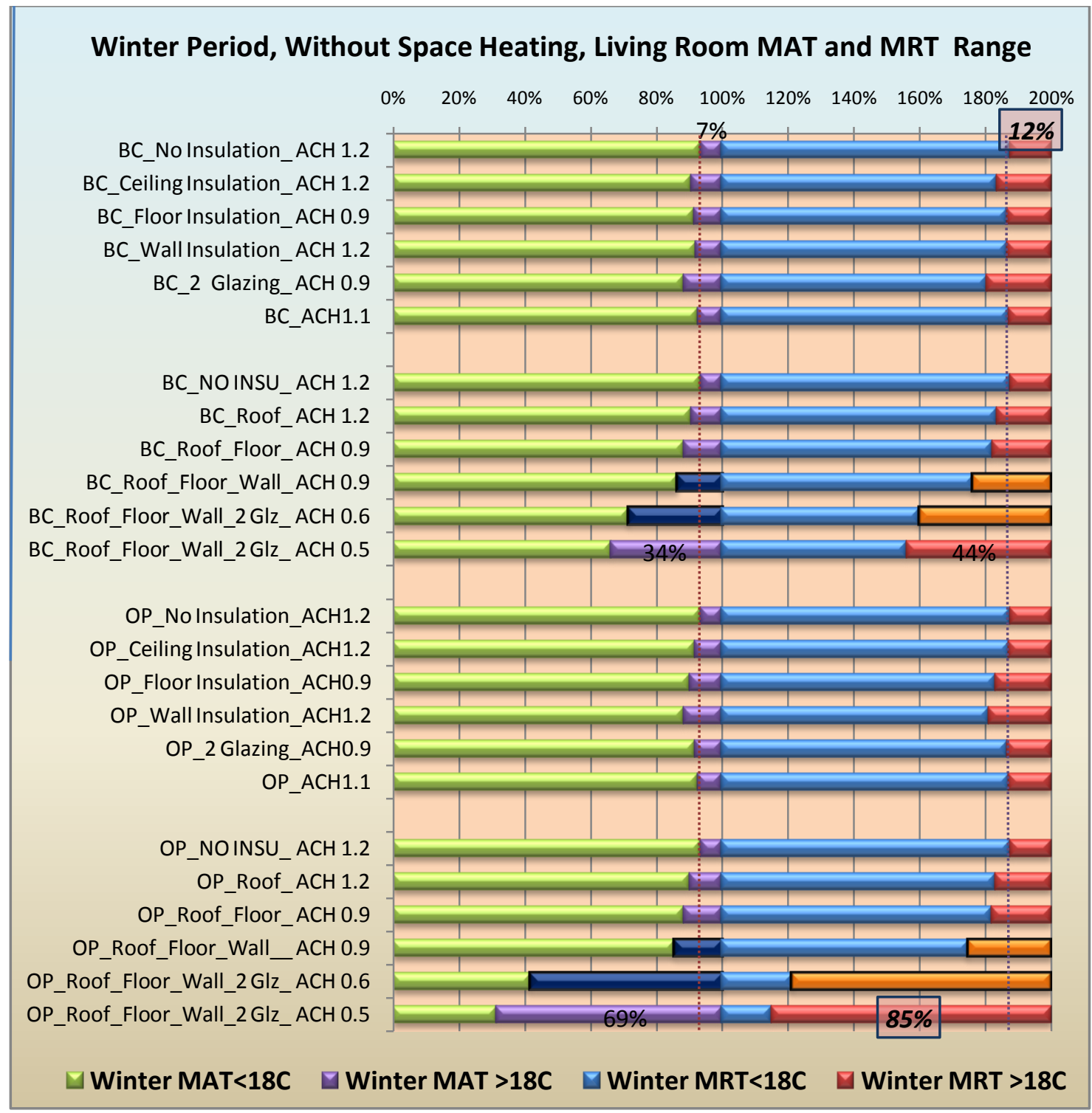

Figure 16: Winter Period, Living Room Mat and MRT Range Band In this study, $18^{\circ} \mathrm{C}$ was recommended as the thermal comfort level for the living room. From the figure above, it can be seen that, for each single step of retrofit, there is around a $1-5 \%$ increase for counted hours of MAT above $18^{\circ} \mathrm{C}$, and a 
$1-8 \%$ increase for MRT. Regarding the optimum level fully insulated house model, for $69 \%$ of winter time, MAT was above $18^{\circ} \mathrm{C}$, and $85 \%$ of the period MRT was above $18^{\circ} \mathrm{C}$, in spite of there being no heating. Also, it was discovered that nearly half of the above percentage of winter comfortable MAT and MRT hours was achievable by full Building Code level insulation retrofit in a no heating simulation.

It has been observed that double glazing makes significant difference of indoor thermal comfort conditions. After double glazing has been adopted, Building Code level retrofit can double the winter comfort time, and Optimum Level retrofit can triple the winter comfort period.

The simulation results of annual average MAT and MRT can be found in Appendix C, Figure 35. The annual simulation gives an overall picture of average MAT and MRT variation for each retrofit option from year round. These MAT and MRT values follow the same increase pattern to winter period results. Because some warmer months are counted in the simulation period, the annual average MAT and MRT results are higher than the ones of winter.

\subsubsection{Discussion}

The simulation results suggest that the thermal efficiency of the defined house model can be improved by adopting higher levels of insulation and air infiltration control. From the simulated results, it is clear that single building element retrofit can achieve only a limited scale of heating energy saving and thermal comfort improvement. Better heating energy performance and high percentage of winter comfort hours can be achieved by adequate insulation for all building elements. Compared with optimum level insulation retrofit, Building Code level upgrading made a relatively lower improvement. The current government supported 
Heatsmart programme, which is intended to provide insulation retrofits in housing, only aims to insulate ceiling and floor, possibly for the reason of easy access and least cost. The results of the simulation tests proved that to reach significantly lower space heating energy requirements and more comfortable indoor temperatures, optimum level insulation retrofit should be adopted for the existing houses. Also, partial building elements retrofit should not be encouraged. To achieve optimum result of building upgrading, the understanding of the benefits of the combined effect of complete house element insulation retrofit with efficient air infiltration control needs to be strengthened.

Simulation results and real situation can be different. Lloyd discovered $20 \%$ difference between simulation result and monitored result from his research (Lloyd et al, 2006, p.C). However, it should also be noted that theoretical performance of higher levels of insulation might not be achieved owing to construction practices, since retrofit workmanship, insulation installation, and thermal bridging may lower its predicted effectiveness.

\subsection{Cost effectiveness analysis}

The previous section analysed the improvement in thermal comfort and heating energy with different retrofit model simulations. In practice, apart from technical points, the cost of upgrading work should also be considered as an important factor for making retrofit decisions.

This cost effectiveness analysis uses the same retrofit models developed in the previous chapter.

The data used in the cost calculations were collected from Rawlinsons Handbook 2009, as well as from phone calls with materials supply company and communication with local builders. 
Each step of retrofit work generally includes the cost of material and labour work. Some retrofit work also incurs some extra costs for building inspection required by the local building authority or for a secondary process, such as removing existing wall internal lining and installing insulation retrofit, and then re-lining the wall.

\subsubsection{Ceiling}

For a house with pitched roof, ceiling insulation retrofit can be done by access into the roof attic. Options can be chosen with different levels of insulation materials.

Option one is one layer of basic level insulation, R2.8, as required by the Building Code. Option two is the optimum level insulation of R4.6. Apart from more insulation material cost, labour and delivery costs of the two options should be the same. Table 26 shows the details of calculation.

\begin{tabular}{|c|c|c|c|c|c|}
\hline \multicolumn{6}{|c|}{ Ceiling Retrofit Cost } \\
\hline Area: & \multicolumn{5}{|c|}{$100.38 \mathrm{~m}^{2}$} \\
\hline \multicolumn{2}{|c|}{} & $\begin{array}{c}\text { Material/ } \\
\mathrm{m}^{2}\end{array}$ & Labour/Hr & $\mathrm{Hrs} / \mathrm{m}^{2}$ & $\begin{array}{c}\text { Insulation } \\
\text { Cost }\end{array}$ \\
\hline $\begin{array}{c}\text { Option_ } \\
\mathbf{1}\end{array}$ & $\begin{array}{c}\text { Code required R2.8 } \\
\text { bulk Insulation } \\
\text { over ceiling batten }\end{array}$ & $\$ 15^{*}$ & $\$ 30 *$ & $0.09 *$ & $\mathbf{\$ 1 , 7 7 7}$ \\
\hline $\begin{array}{c}\text { Option_ } \\
\mathbf{2}\end{array}$ & $\begin{array}{c}\text { R4.6 Bulk } \\
\text { insulation over } \\
\text { ceiling batten }\end{array}$ & $\$ 23^{*}$ & $\$ 30 *$ & $0.09 *$ & $\mathbf{\$ 2 , 5 8 0}$ \\
\hline
\end{tabular}

Table 26: Ceiling Retrofit Cost

\subsubsection{Floor}

Similar to ceiling insulation retrofit, costs of two different floor insulation options were calculated for Building Code level and optimum level. These floor

\footnotetext{
* Price quoted from Rawlinsons Handbook 2009
} 
insulation retrofits can be carried out with the assumption of underfloor accessibility.

For option two, the detail was given in chapter 10.1.3. Bulk insulation R4.6 with fibre cement board fixed at floor joist bottom. A layer of polythene covering can be put on the natural ground to provide some moisture control. The calculation did not include polythene covering.

\begin{tabular}{|c|c|c|c|c|c|c|}
\hline \multicolumn{7}{|c|}{ Floor Retrofit Cost } \\
\hline \multirow{2}{*}{ Area: } & \multirow{2}{*}{$100.38 m^{2}$} & \multirow{2}{*}{\multicolumn{2}{|c|}{$190 \mathrm{~mm}$ Joist at 400}} & Timber & $11.30 \%$ & $11 \mathrm{~m}^{2}$ \\
\hline & & & & Space & $88.70 \%$ & $89 \mathrm{~m}^{2}$ \\
\hline & & $\begin{array}{c}\text { Material } \\
/ \mathrm{m}^{2}\end{array}$ & $\begin{array}{c}\text { Labour/ } \\
\mathrm{Hr}\end{array}$ & $\mathrm{Hrs} / \mathrm{m}^{2}$ & \multicolumn{2}{|c|}{ Insulation Cost } \\
\hline $\begin{array}{c}\text { Option_ } \\
1\end{array}$ & $\begin{array}{l}\text { Building Code, } \\
\text { Reflective Foil for } \\
\text { underfloor }\end{array}$ & $\$ 7.2^{*}$ & $\$ 30 *$ & $0.12 *$ & \multicolumn{2}{|c|}{$\$ 1,084$} \\
\hline \multirow{4}{*}{$\begin{array}{l}\text { Option_ } \\
2\end{array}$} & $\begin{array}{l}\text { R4.6 Bulk } \\
\text { insulation }\end{array}$ & $\$ 23 *$ & $\$ 30 *$ & $0.09 *$ & \multicolumn{2}{|c|}{$\$ 2,580$} \\
\hline & \multirow{2}{*}{$\begin{array}{l}\text { Medium Density } \\
\text { Fibreboard lining }\end{array}$} & $\begin{array}{c}\text { Material } \\
/ \mathrm{m}^{2}\end{array}$ & $\mathrm{Hrs} / \mathrm{m}^{2}$ & Material & $\begin{array}{c}\text { Material } \\
\qquad / \mathrm{M}^{2}\end{array}$ & \\
\hline & & $\$ 18.50 *$ & $0.4^{*}$ & $\begin{array}{c}\text { Angle } \\
\text { brace } \\
5.90 / \mathrm{m} *\end{array}$ & $\$ 29.50 *$ & 0.12 \\
\hline & Total Extra Cost & \multicolumn{5}{|c|}{$\$ 4,320$} \\
\hline
\end{tabular}

Table 27: Floor Insulation Retrofit Cost

\subsubsection{Wall}

There are basically two methods for wall insulation retrofit. Option one is using AIRFOAM insulation, which provides a method by filling insulation from outside of the exterior wall and makes fewer disturbances to house occupants.

Option two needs the removal of the internal lining before insulation material

\footnotetext{
* Price quoted from Rawlinsons Handbook 2009
} 
can be fitted in between wall studs and noggins. After that, relining, painting and skirting work may be involved. Local council inspection may also be needed for reinstalling internal lining bracing. The cost of rubbish collection is also included. For this wall insulation retrofit option, R-value can be assured by installing bulk insulation.

\begin{tabular}{|c|c|c|c|c|c|c|}
\hline \multicolumn{7}{|c|}{ Wall Retrofit Cost } \\
\hline \multirow{2}{*}{ Area: } & \multirow{2}{*}{$107.04 m^{2}$} & \multirow{2}{*}{\multicolumn{2}{|c|}{$\begin{array}{l}\text { Studs @ 600, } \\
\text { Dwangs @800 }\end{array}$}} & Timber & $14 \%$ & $15 \mathrm{~m}^{2}$ \\
\hline & & & & Space & $86 \%$ & $92 \mathrm{~m}^{2}$ \\
\hline $\begin{array}{c}\text { Option_ } \\
1\end{array}$ & \multicolumn{4}{|c|}{ Exterior wall insulation injection AIRFOAM. } & \multicolumn{2}{|c|}{$\$ 1,800^{6}$} \\
\hline \multirow{6}{*}{$\begin{array}{c}\text { Option } \\
2\end{array}$} & \multirow{2}{*}{$\begin{array}{l}\text { Install R2.8 } \\
\text { insulation }\end{array}$} & $\begin{array}{l}\text { Material } \\
/ \mathrm{m}^{2}\end{array}$ & $\begin{array}{c}\text { Labour/ } \\
\mathrm{Hr}\end{array}$ & $\mathrm{Hrs} / \mathrm{m}^{2}$ & \multicolumn{2}{|c|}{$\begin{array}{l}\text { Insulation and } \\
\text { installation Cost }\end{array}$} \\
\hline & & $\$ 22.00^{*}$ & $\$ 30^{*}$ & $0.06^{*}$ & \multicolumn{2}{|c|}{$\$ 2,191$} \\
\hline & \multirow[b]{2}{*}{$\begin{array}{l}\text { Remove GIB } \\
\text { and Skirting }\end{array}$} & $\begin{array}{l}\text { Material } \\
/ \mathrm{M}^{2}\end{array}$ & $\mathrm{Hrs} / \mathrm{M}^{2}$ & Material & $\begin{array}{c}\text { Material/ } \\
\mathrm{M}^{2}\end{array}$ & $\mathrm{Hrs} / \mathrm{M}^{2}$ \\
\hline & & -- & $0.15^{7}$ & $\begin{array}{l}\text { Reinstall } \\
\text { GIB and } \\
\text { Skirting, } \\
\text { Re-painting }\end{array}$ & $\$ 64.45 *$ & $0.50 *$ \\
\hline & $\begin{array}{l}\text { Electrician } \\
\text { work Total }\end{array}$ & $\$ 300^{8}$ & $\begin{array}{l}\text { Rubbish } \\
\text { Dump }\end{array}$ & $\$ 150 *$ & $\begin{array}{l}\text { Council } \\
\text { Fee Total }\end{array}$ & $\$ 538^{9}$ \\
\hline & Total Cost & & & $\$ 7,110$ & & \\
\hline
\end{tabular}

Table 28: Wall Insulation Retrofit Cost

\footnotetext{
${ }^{6}$ Price quoted from telephone inquiry with AIRFOAM.

*Price quoted from Rawlinsons Handbook 2009

${ }^{7}$ Price quoted from personal communication with local builder

*Price quoted from Rawlinsons Handbook 2009

8 Price quoted from personal communication with local builder

${ }^{9}$ Price quoted from Wellington City Council website Building Consent Fees. http://www.wellington.govt.nz/services/buildserv/buildcon/fees.html
} 


\subsubsection{Double glazing}

For window retrofit, two options were compared. Option one gives a double glazing solution by adding a layer of acrylic at the inside edge of the window frame secured by magnetic tape. New Zealand based 'MagicSeal' claims that magnetic attached acrylic sheet secondary glazing has an R-value of $0.37 \mathrm{~m}^{2} \mathrm{~K} / \mathrm{W}$ (MagicSeal, 2007). The inconvenience of this option is that one whole layer of acrylic attached inside of the window frame makes the window effectively fixed. Also, air tightness control of this option is not as good as new window unit. So, the thermal performance of attached acrylic sheet secondary glazing is probably less effective than that for a replacement window.

Although, some work can be done on the existing windows by fitting another pane in the existing window frame, Lloyd's house upgrading study (Lloyd and Callau, 2006, p.B) indicated that window retrofit work by fitting in a second pane was more expensive than replacing with new double glazing window units. New window frames also reduce air infiltration heat loss. This solution is adopted as option two for double glazing retrofit.

\begin{tabular}{|c|c|c|c|}
\hline \multicolumn{4}{|c|}{ Window Retrofit Cost } \\
\hline Area: & \multicolumn{3}{|c|}{$30.09 m^{2}$} \\
\hline & & Material/ $\mathrm{m}^{2}$ & Cost \\
\hline Option_1 & Magnetic attached acrylic & $\$ 106^{10}$ & $\$ 3,198$ \\
\hline Option_2 & $\begin{array}{l}\text { Replace with new double } \\
\text { glazing windows }\end{array}$ & $\$ 440 *$ & $\$ 13,240$ \\
\hline
\end{tabular}

Table 29: Window Retrofit Cost

\footnotetext{
* Price quoted from Rawlinsons Handbook 2009

${ }^{10}$ Price quoted from Lloyd, B., Bishop, T., and Callau, M. 2007. Retrofit Alternatives for State Houses in Cold Regions of New Zealand-Report 2. P.21
} 


\subsubsection{Air tightness}

Currently, there are many draught seal strips on the market with reasonable price. This is also a simple house upgrading solution and can be done by householders. The required length of seal strips was calculated with the gap dimension of windows and doors.

\begin{tabular}{|c|c|c|c|}
\hline \multicolumn{4}{|c|}{ Air Draught Retrofit Cost } \\
\hline Length: & \multicolumn{3}{|c|}{$90.6 m^{11}$} \\
\hline & & Material/ $\mathrm{m}^{2}$ & Cost \\
\hline Option_1 & $\begin{array}{c}\text { Install Draught Control } \\
\text { Seal Strips }\end{array}$ & $\$ 4.7^{12}$ & $\$ 426.93$ \\
\hline
\end{tabular}

Table 30: Draught Control Cost

Below, the two figures present the retrofit cost by different groups, retrofit elements and retrofit combinations. For ceiling insulation, the cost of Building Code level insulation is quite similar to optimum level insulation. As discussed before, the only difference is in the insulation material. For other options, the cost varies considerably due to the different design and material costs.

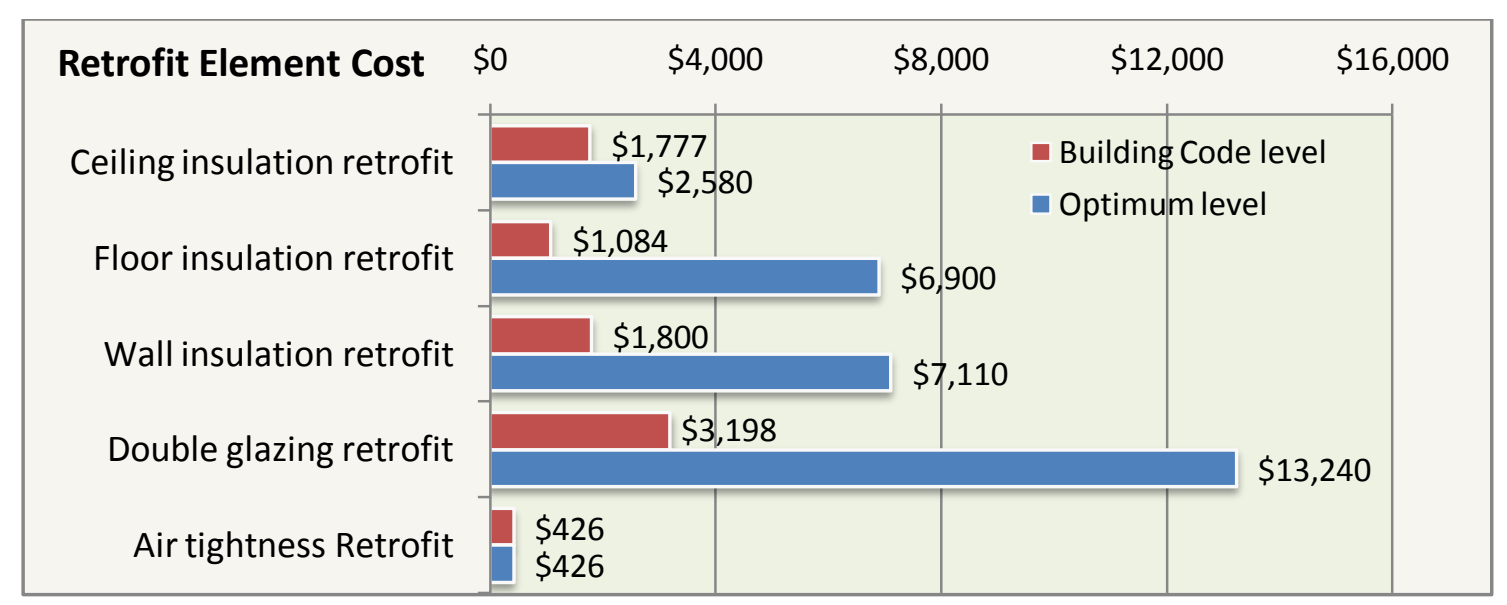

Figure 17: Retrofit Element Cost

${ }^{11}$ Length measured from the dimensions of windows and doors from the National Modal House. Plans can be found in Appendix $B$.

${ }^{12}$ Draught proofing strips price quote from Community Energy Action Charitable Trust website http://www.cea.co.nz/home-insulation/\#Windowanddoor 
Thermal Simulation of Building Envelope Retrofit

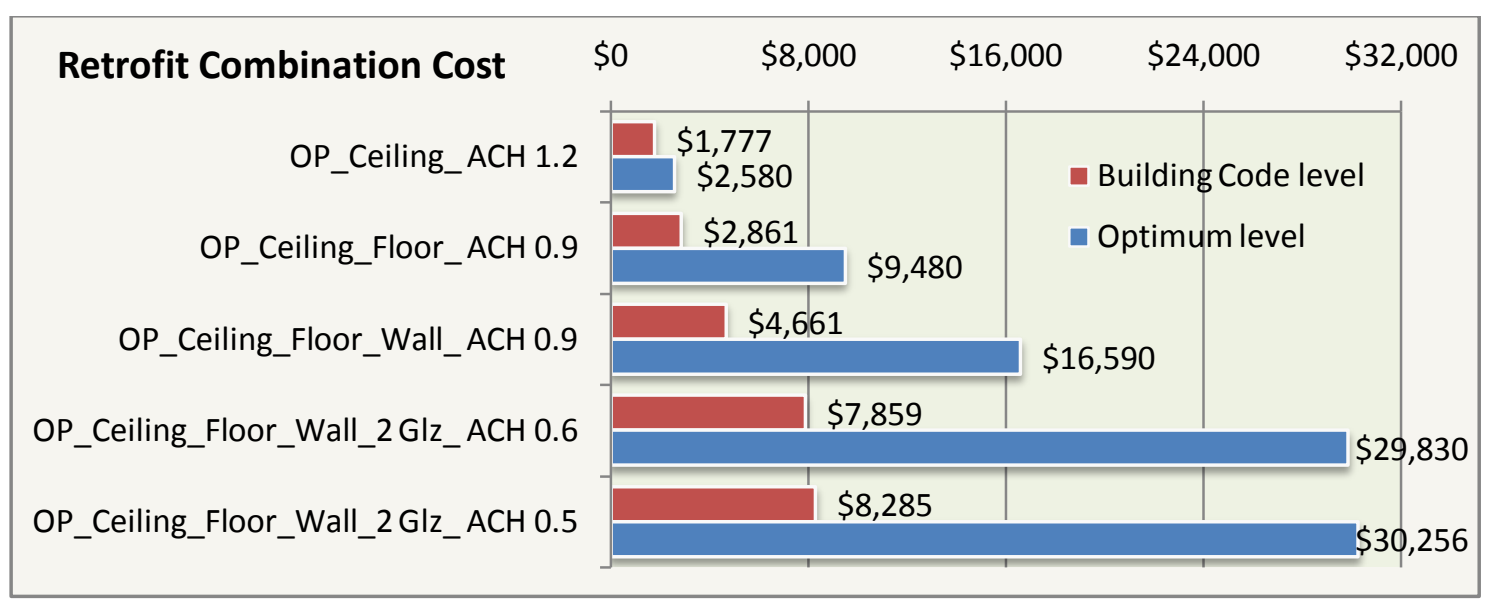

Figure 18: Retrofit Combination Cost

According to the benefit of double glazing retrofit, $68.6 \%$ ([\$7589$\$ 4661] / \$ 7589=68.9 \%$ ) of total Building Code Level retrofit cost can achieve $60.7 \%$ (Table 24, p.95) of heating energy reduction, and 79.8\% ([\$29830$\$ 16590] / \$ 29830=79.8 \%$ ) of Optimum Level retrofit cost can save $86.2 \%$ (Table 24, p.95) of heating energy.

Figure 19 gives a comparison of space heating energy saving and cost of each step of combined retrofit options. Space heating energy saving and retrofit cost followed the similar pattern. The more house insulation and air tightness retrofit work is carried out, the more space heating energy would be saved.

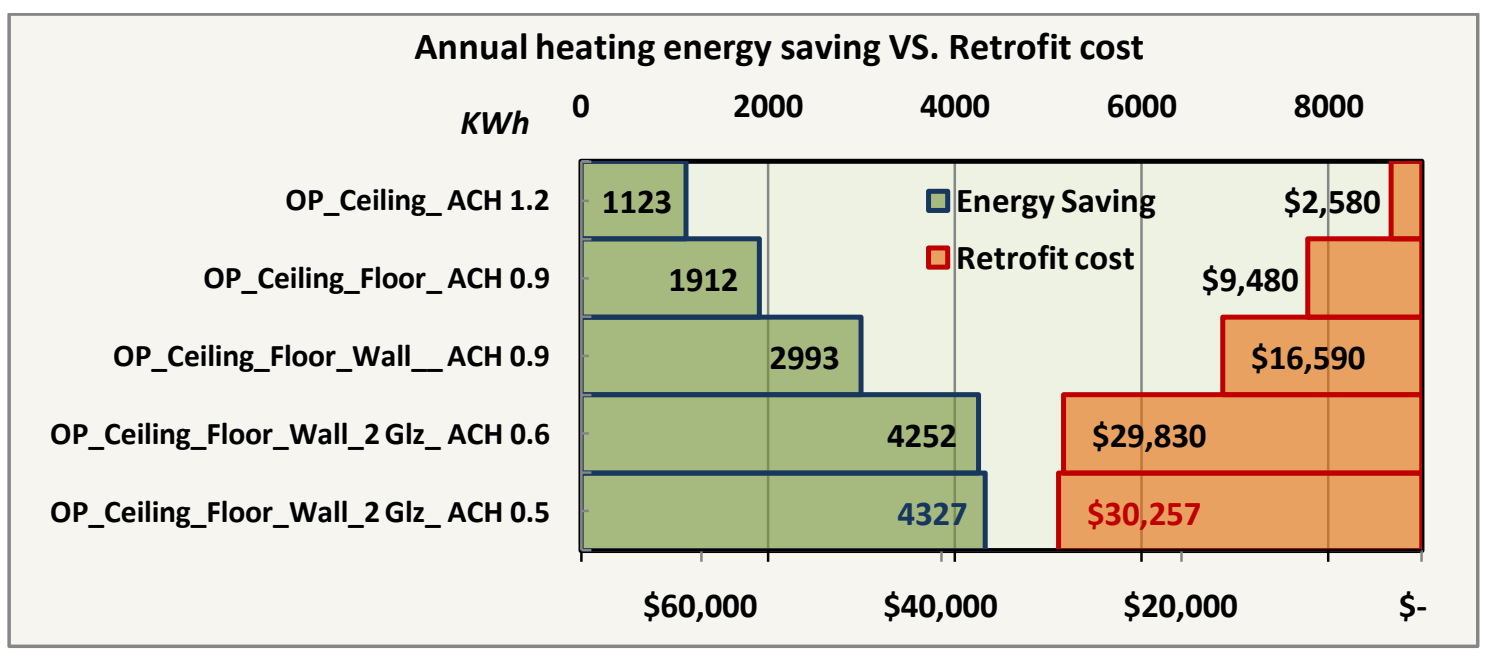

Figure 19: Annual Heating Energy Saving and Retrofit Cost

From 1974 to 2008 is 34 years, over this time the domestic electricity price has 
gone from $\$ 0.1076$ to $\$ 0.2369 / \mathrm{KWh}$, an increase of $\$ 0.1293$, or $120 \%$ (based on 2008 real price). Currently, the average electricity price is $\$ 0.25 / \mathrm{KWh}$ (Ministry of Economic Development, 2010). Optimum level full insulation retrofit could make space heating energy savings of $4327 \mathrm{kWh}$, which equals to $\$ 1082$ saving. It costs $\$ 30257$ to upgrade the house, and with current power cost, the upgrade costs the same as $6051 \mathrm{KWh}{ }^{13}$ per year over 20 years. However, if electricity price cost doubles over the period of the loan, the cost will be equal to $3026 \mathrm{KWh}$ in 20 years time.

${ }^{13} \$ 30257 \div \$ 0.25 / \mathrm{KWh} \div 20$ years $=6051 \mathrm{KWh} /$ year 


\section{Space Heating Equipment Retrofit}

The space heating system retrofit needs to follow a certain order. Generally, it should adopt the rule of retrofitting the house with insulation first and then upgrading the heating equipment. By doing this, it can be possible to achieve both thermal comfort and energy saving.

Making the maximum installation of insulation in a building is the first target of house upgrading. Once the best insulation and airtightness that can be applied for the existing house circumstances is achieved, the selection of heating system should start with consideration of the simplest and cheapest running options, in combination with the amount of heat needed to bring the space to comfortable temperatures.

From the result of the previous chapter, it can be seen that sufficient insulation retrofit can help to remarkably reduce space heating demand to maintain a reasonable level of thermal comfort.

Internal heat gains from appliances, lighting and people can contribute significantly to house heating, but heating equipment is necessary to provide the main contribution in most buildings.

Under the New Zealand climate, most houses need some forms of heating. Efficiency is an important factor. At present, various technologies have been improved, such as the electric heat pump to replace the direct electric heater and the clean-burning wood pellet heater to replace the wood burner. The heat pump has increased in popularity, from 4\% in 2002 to $19 \%$ in 2007 (French, 2008, p.3-9). Howden-Chapman et al (2009, p. 3394) suggested heat pumps are as particularly efficient source of space heating only when they replace the use of other electric heating methods. 
The rule of thumb for heating system upgrading is that if a heater uses an unrenewable energy source (electricity is not generated solely from renewable sources such as hydro or wind) it should not replace one run by a renewable energy source, such as wood. Therefore, it is recommended replacing lower efficiency wood burners and open fires with new, cleaner wood burners or pellet fires. Wood burners should not be replaced with heat pumps, as heat pumps still have the potential to increase winter electricity demand and may lead to electrical issues and higher carbon emissions for New Zealand.

It is believed that the same amount of heating energy input will result in higher temperature in insulated houses than the original ones. To receive the benefits of higher insulation, less heating is expected to be used to maintain the same temperature.

Traditional forms of heating are being replaced by newer and more energyefficient approaches. However, the traditional New Zealand heating pattern has not been changed for years. Normally, New Zealand households only heat one room of the house. This heating pattern has not been changed for years. (Howden-Chapman et al, 2006, p.3387)

Isaacs et al (2006, p.57) found out that, within HEEP's 397 house samples, houses heated by solid fuel heating are the warmest, with houses heated by portable LPG and electric heaters the coldest. The best and cheapest source of heat is the Sun. However, for retrofit solutions, building orientation and solar heat gain are not easily changed. The means of house heating is very dependent on the house envelope structure, the material applied and heating system efficiency. 


\subsection{Features of New Zealand house heating}

The HEEP project monitored 3 winter months indoor temperature of the random selected house samples. On average, temperatures of living rooms are below $20^{\circ} \mathrm{C}$ for $83 \%$ of the time. The living room is the most commonly heated room and the warmest room in the house (French et al, 2006, p.8).

It is common practice in New Zealand for households to heat only one room (usually the living room), or at the most to heat the living room and one or two of the bed rooms (Isaacs et al., 2003, p.30). Central heating of the whole house is uncommon, with only about $5 \%$ of homes heated this way (Ministry for the Environment, 2005)

\begin{tabular}{|c|c|c|c|}
\hline \multicolumn{4}{|c|}{$\begin{array}{c}\text { Percentage of Fuel Types Used to Heat Dwellings (total responses) for } \\
\text { Private Occupied Dwellings 1996, 2001 and 2006 Censuses }\end{array}$} \\
\hline Fuel types & 1996 & $\mathbf{2 0 0 1}$ & $\mathbf{2 0 0 6}$ \\
\hline Electricity & $77.2 \%$ & $72.0 \%$ & $74.8 \%$ \\
\hline Mains gas & $11.6 \%$ & $13.5 \%$ & $13.2 \%$ \\
\hline Bottled gas & $22.3 \%$ & $28.3 \%$ & $27.7 \%$ \\
\hline Wood & $48.7 \%$ & $44.7 \%$ & $40.9 \%$ \\
\hline Coal & $13.0 \%$ & $9.3 \%$ & $7.0 \%$ \\
\hline Solar power & $0.7 \%$ & $0.9 \%$ & $1.1 \%$ \\
\hline No fuels used in this dwelling & $0.9 \%$ & $2.8 \%$ & $2.4 \%$ \\
\hline Other fuel(s) & $1.9 \%$ & $1.1 \%$ & $2.1 \%$ \\
\hline
\end{tabular}

Table 31: Heating Fuel Types and Proportion

(Source: Statistic New Zealand, 2007, p.14)

The data given by Statistics New Zealand Censuses show that, over the 10 years period, the number of houses using wood as heating fuel has decreased from 48.7 percent in 1996 to 40.9 percent in 2006 . Also, $74.8 \%$ of homes used electricity for heating in 2006. But this table only reports how many houses 
make use of the different fuels, and electricity is not necessarily the principal means of heating, so percentages will not sum to 100 .

BRANZ collected another set of space heating fuel data from the HEEP project. As below:

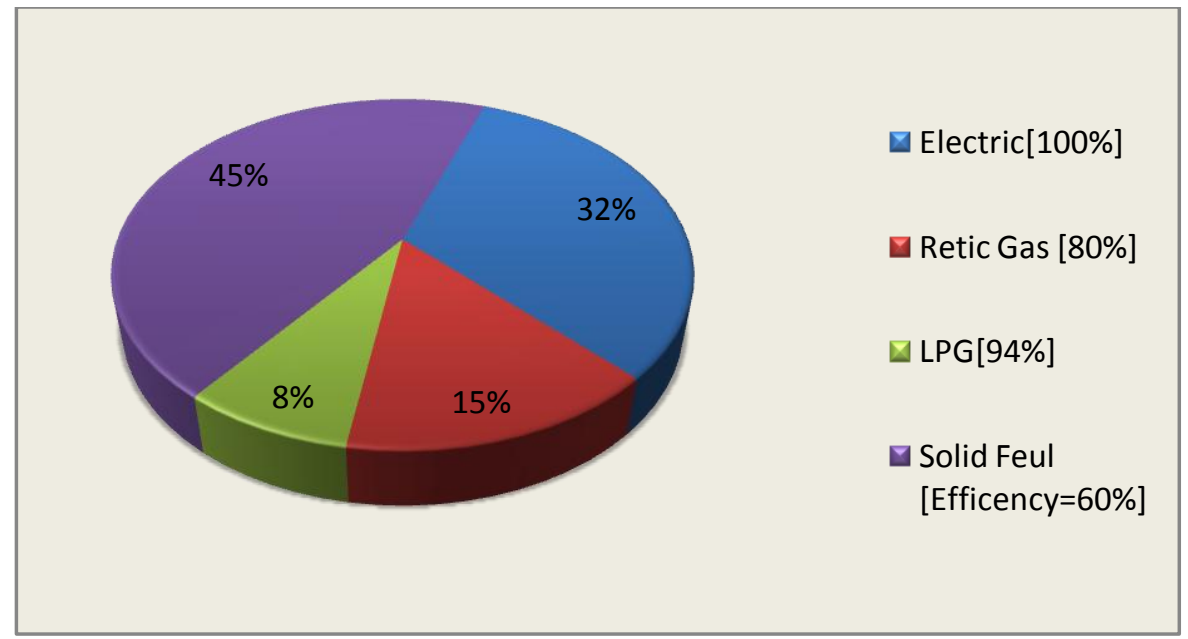

Figure 20: Space Heating Energy by Fuel.

(Source: HEEP year 10 Report. Isaacs et al, 2006, p.19)

Figure 20 reports the share of different types of heating fuels for space heating. The principal means of heating is solid fuel $45 \%$, followed by electricity at $32 \%$. Normally, the heating fuel is determined by the system selection of the original house owner or builder. 


\subsection{Retrofit solutions}

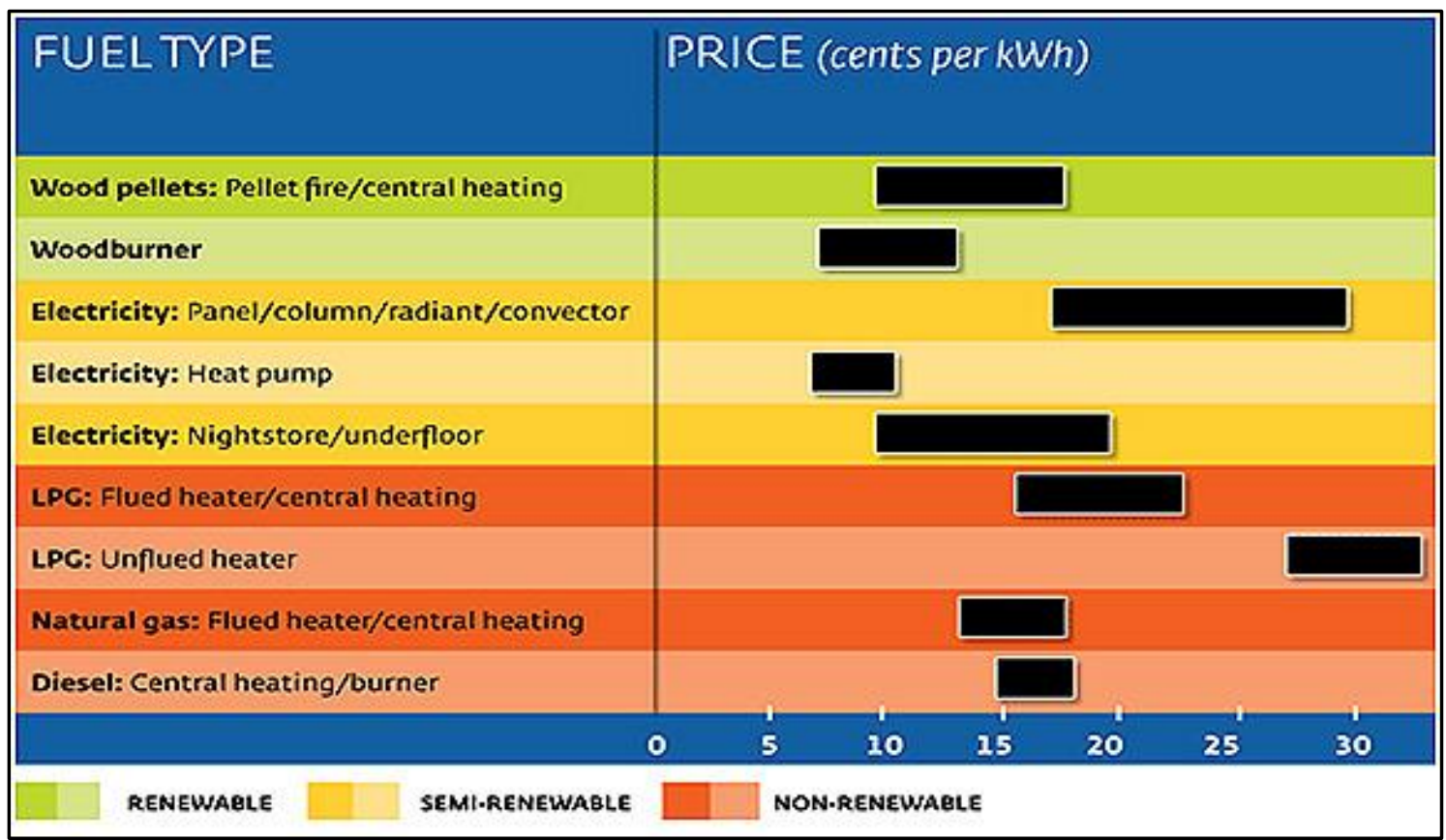

Figure 21: Heating System Fuel Type and Running Price.

Source: (Consumer, 2010. Prices were correct as at March 2009.)

Figure 21 shows the difference between heating systems with fuel type and operation price. The level of environmental friendliness depends on fuel type, which is presented in different colour rows defined as renewable (wood), semirenewable (electricity) and non-renewable (gas). The heat pump is the cheapest way for space heating, with a cost in 2009 of about 7-11cents per KWh. Unflued LPG heater is the most expensive option, nearly three times the heat pump running cost. It is interesting to see that a conventional (i.e. non-pellet) wood burner can be as cheap as a heat pump to operate, and it uses a renewable fuel.

The following points should be considered when retrofitting a heating system:

- The energy source and cost, it should use the least amount of purchased energy to produce required level of heat output.

- How efficient the heating device is in converting the energy to heat 
- The ability to thermostatically control the heat output once the optimum temperature is reached

- The activities and age of the occupants.

\subsection{Heating system selection}

To understand the features of different types of heating equipment and help to make decisions on retrofit, different heating methods are compared as below:

\begin{tabular}{|c|c|c|}
\hline $\begin{array}{l}\text { Heating } \\
\text { method }\end{array}$ & Advantage & Disadvantage \\
\hline Heat pump & $\begin{array}{l}\text { - Cheap to run } \\
\text { - No indoor air emissions } \\
\text { - Easy to use }\end{array}$ & $\begin{array}{l}\text { - Relies on electricity } \\
\text { - Expensive to install }\end{array}$ \\
\hline $\begin{array}{c}\text { Oil-filled } \\
\text { heater }\end{array}$ & $\begin{array}{l}\text { - No indoor air emissions } \\
\text { - Easy to use } \\
\text { - No need for installation }\end{array}$ & $\begin{array}{l}\text { - Relies on electricity } \\
\text { - Expensive to run }\end{array}$ \\
\hline Unflued gas & - No need for installation & $\begin{array}{l}\text { - Causes dampness inside } \\
\text { - Raises the level of nitrogen dioxide in } \\
\text { the air inside } \\
\text { - Difficult to refill fuel supply } \\
\text { - Expensive to run - Methods of finding } \\
\text { fuel not environmentally friendly } \\
\text { - Need for fuel to be distributed } \\
\text { nationwide by road } \\
\text { - Releases carbon dioxide and other } \\
\text { gases into the air }\end{array}$ \\
\hline Flued gas & $\begin{array}{l}\text { - Cheap to run } \\
\text { - No indoor air emissions } \\
\text { - Easy to use }\end{array}$ & $\begin{array}{l}\text { - Expensive to install } \\
\text { - Methods of finding fuel not } \\
\text { environmentally friendly } \\
\text { - Need for fuel to be distributed } \\
\text { nationwide by road } \\
\text { - Releases carbon dioxide and other } \\
\text { gases into the air }\end{array}$ \\
\hline $\begin{array}{l}\text { Wood } \\
\text { burner }\end{array}$ & $\begin{array}{l}\text { - Fuel is free (or cheap) for } \\
\text { - Renewable energy } \\
\text { source } \\
\text { - Carbon neutral fuel } \\
\text { source }\end{array}$ & $\begin{array}{l}\text { - Low efficiency and hard to control } \\
\text { - Dirty fuel to handle } \\
\text { - Expensive to install } \\
\text { - Air pollution (smoke and sulphur } \\
\text { dioxide, made worse by use of wet } \\
\text { fuel) }\end{array}$ \\
\hline
\end{tabular}

Table 32: Heating Systems Comparison

The wood burner plays an important part for space heating. Most solid fuel burners can produce over $10 \mathrm{KW}$ - enough to heat most New Zealand homes to 
comfortable temperature (Thomas, 2007, p.5).

In fact, solid fuel burners have a big share of fuel consumption for space heating. If domestic solid fuel burners were removed, New Zealand would need more power stations to meet the demanding for heating electricity use.

Unflued gas heaters create heat by gas combustion directly into the house air. This causes higher levels of condensation due the vapour released from burning. Sufficient ventilation will be needed to support full combustion and remove $\mathrm{CO}_{2}$.

From the simulation result from previous chapter, the annual required heating energy of the 24 hours heating scheme is $4454 \mathrm{KWh}$ and $127 \mathrm{KWh}$ for the uninsulated house and the optimum level full insulated house respectively. For the full insulated house, since required heating energy has been reduced to a very low level, portable electric heaters can be the most cost effective way to supply heat through a year when it is needed. One oil-filled heater can meet the heating need for each heating zone (living room and bedrooms). An example is the DeLonghi DL2401TF ${ }^{(14)}$ model oil-filled heater (maximum load 2.4KW). The cost of this heater is $\$ 150$ each and it is operated by temperature set point and timer (CONSUMER, 2010). This means different heaters in different rooms can be operated by time period and temperature set point, according to occupants' needs. By adopting this low-cost approach, thermal comfortable temperature can be easily maintained and it can also solve the problem of only heating part of the house.

\footnotetext{
${ }^{14}$ Heater model and price quoted from Consumer NZ. http://www.consumer.org.nz/reports/oil-filled-heaters/we-recommend
} 


\section{Hot Water Heating System Retrofit}

In New Zealand, of the $\$ 3000$ million paid for residential electricity every year, approximately, 31\%, $\$ 950$ million is used for water heating (Pollard, 2008, p.53). Energy efficient measures can be made by using solar water heating or a heat pump water heating system. Reducing the energy use in a water heating system can also be simple and low cost solutions, which include ensuring the hot water cylinder is well insulated, reasonable temperature setting point and that low-flow water taps and showerheads are installed.

\subsection{Features of New Zealand hot water heating}

Compare to other retrofit items, one characteristic of the hot water cylinder is that it is rarely maintained and replaced. Also, energy saving is not very much noticed. The HEEP project indicated that $46 \%$ of the cylinders are the same age as the dwelling (Isaacs, 2005, p.92).

Pollard's figure of $31 \%$ may be low, according to the finding of Isaacs et al, on average, $34 \%$ of New Zealand household energy is used to heat water and maintain it to a set temperature (Isaacs et al, 2006, p.19).

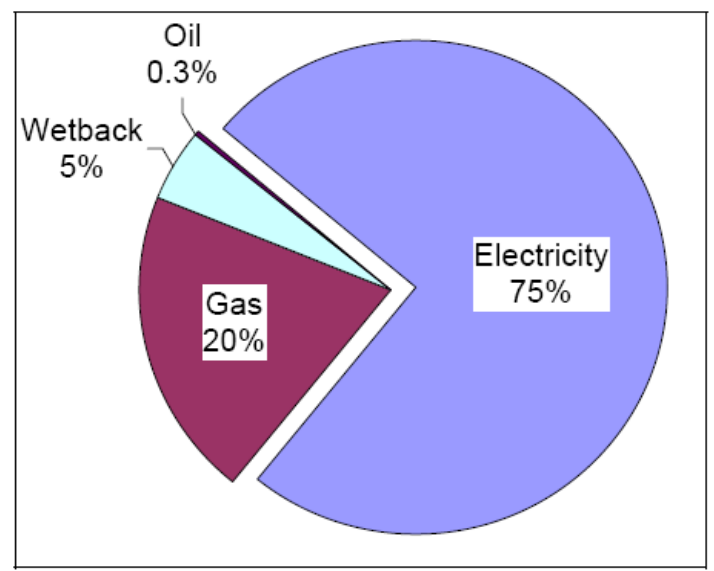

Figure 22: Break Down of Hotwater Fuel Types

(Source: HEEP year 10 report, Isaacs et al, 2006, p.102)

The above chart shows that, overall, New Zealand homes are very much 
dependent on electricity to heat hot water. Isaacs et al (2005, p.94) discovered that the majority of the HEEP hot water systems, $71 \%$ of the house samples have one electric storage water cylinder. Thus, it is clear that the electric hot water cylinders can be the biggest target for hot water heating retrofit.

The energy used by hot water systems tends to be driven by two key performance factors. The first one is the technical factor. The heating system thermal efficiency is largely depending on system design, manufacture, installation and maintainance. To take the hot water cylinder for example, standing heat loss, cylinder insulation and cylinder size could make a considerable difference to power use. The other performance factor is occupants' behaviour, the usage of hot water which can be driven by the users e.g. thermostat setting, length of use, type of use, etc. The way people use hot water has changed in New Zealand. In the early 1970's only $41 \%$ of people used to use the shower as their main form of washing, more recently, $94 \%$ use the shower rather than the bath (Isaacs et al, 2005, p.84).

From the technical point, there are three main factors affecting energy use of hot water heating: heating set temperature, water delivery pressure and cylinder size. The amount of energy stored in the hot water cylinder is directly related to the cylinder volume and water temperature.

There are two main types of hot water cylinders most comonly used in existing New Zealand existing houses: 135 litres and 180 litres, and there are quite equal numbers of each type, both comprise around $40 \%$ of the existing water heating systems (Isaacs et al, 2005, p.97).

For the reason of safety related to temperature, New Zealand Building Code Clause G12 gives the following requirement. Hot water supplied to sanitary 
fixtures provided for personal hygiene (e.g. showers, baths, hand basin) should be a maximum of $45^{\circ} \mathrm{C}$ for places such as childcare centres; schools; old people's homes; etc. Elsewhere the maximum temperature to such fixtures should be $55^{\circ} \mathrm{C}$ (Department of Building and Housing, 2007B, p.37).

In New Zealand, many hot water cylinders operate with a high thermostat set point.

\begin{tabular}{|c|c|}
\hline Tap $>\mathbf{6 0}^{\circ} \mathbf{C} \&$ Thermostat $<=\mathbf{6 0}^{\circ} \mathbf{C}$ & Tap $>\mathbf{6 0}^{\circ} \mathbf{C} \&$ Thermostat $>\mathbf{6 0}^{\circ} \mathbf{C}$ \\
$17 \%$ & $43 \%$ \\
\hline Tap $<=\mathbf{6 0}^{\circ} \mathbf{C} \&$ Thermostat $<=\mathbf{6 0}^{\circ} \mathrm{C}$ & Tap $<=\mathbf{6 0}^{\circ} \mathbf{C} \&$ Thermostat $>\mathbf{6 0}^{\circ} \mathrm{C}$ \\
$18 \%$ & $21 \%$ \\
\hline
\end{tabular}

Table 33: Tap Hot Water Temperatures and Cylinder Thermostat Temperatures of HEEP Monitored Houses

(Source: HEEP year-9 report. Isaacs et al, 2005, p.iv).

The above figure shows $60 \%$ of tap hot water is delivered at unsafe temperature (over $60^{\circ} \mathrm{C}$ ). Nearly two thirds of cylinders have temperature setting point higher than $60^{\circ} \mathrm{C}$.

Normally the required hot water supply temperature can be controlled by fitting a tempering valve to the cylinder.

It is estimated that $79 \%$ of hot water systems use low pressure cylinders (Isaacs et al, 2006). This means energy saving margin exist for another $21 \%$ cylinders. The delivered hot water pressure can be reduced by low pressure tap fittings or shower heads.

A considerable amount of heat is lost through the cylinder wall and the distribution pipes. For all type of hot water storage, energy is lost through the cylinder even if no hot water is being used. This is normally called 'standing losses'. Isaacs et al (2005) estimated that on average standing heat loss for electric hot water cylinders are about one third of the total hot water energy use. Standing loss always occurs, and it can be considerable for the high 
temperature set point cylinders due to the bigger temperature difference to the ambient temperature and corresponding high heat exchange rate.

The common method to reduce standing loss is installation of cylinder wrap and pipe insulation. Isaacs et al (2005) estimated that wrapped cylinders have standing loss of $1.0 \mathrm{KWh} /$ day less than unwrapped 135 litre cylinders, and $0.6 \mathrm{KWh}$ per day for 180 litre ones. If these are the typical energy savings for wrapping cylinders, the ongoing energy saving can be $365 \mathrm{KWh} /$ year for 135 litre cylinders and $219 \mathrm{KWh} / \mathrm{year}$ for 180 litre ones, with the retail electricity cost of $\$ 66$ and $\$ 39.6$ respectively.

Cylinder wrapping costs between $\$ 60$ and $\$ 100$, depending on the size (RIGHTHOUSE, 2010). Therefore, the payback period is around 1-3 years.

\subsection{Solar water heating}

Although heat pump technology can provide high efficiency water heating system, it is run by electricity, and therefore it is believed not an optimum solution for hot water system retrofit. Solar water heating systems use basically a free source of energy and do not produce $\mathrm{CO}_{2}$ emissions, apart from those related to the energy used when there is insufficient solar radiation to heat the water. Under New Zealand climate circumstances, solar hot water system should be suggested for retrofit.

In December 2003, it is reported that there were some 22,000 (1.4\%) of houses that had been fitted with solar water heaters. EECA estimates that 2000 new solar heating systems are installed each year (Pollard, 2008, p. 58).

Most solar hot water system manufacturers claim that $65-75 \%$ savings can be achieved compared to a standard electric cylinder (EECA, 2007, p.3).

For an existing house, some additional cost may occur for piping work to access 
the solar collector and structural framing work to support the solar water system on the roof.

The amount of sunshine falling on the roof of an average sized home in a year is equivalent to around 200,000 KWh (EECA, 1997, p.2). This is almost 20 times the total electricity requirements of a family home, or 50 times the hot water heating requirements.

The current solar heating uptake is very low in New Zealand. Only around 2\% of houses currently use solar energy for hot water heating (Pollard, 2008, p.53). In the aspect of national policy, some efforts have been made by the New Zealand government in solar water heating system application. Building Code Clause G12 Water supplies has also been modified with an Acceptable Solution for Solar Heating System in 2007. This allows reducing compliance costs and improving the quality for installations. The New Zealand government has announced that a grant of $\$ 1000$ per house can be claimed for the solar heating system cost, if a household meets the eligibility criteria (Pollard, 2008 p.53).

Solar water heating efficiency can be affected by the following points:

a. Solar collector position and tilt angle, which should at least be equal to the latitude of the site.

b. System installation and working to meet the specifications.

c. Back flow control in Open Systems.

d. Well insulated cylinders

e. Users operation of the timer control.

One survey undertake by CRESA (Centre for Research Evaluation and Social Assessment) found out that $86 \%$ of the interviewees would recommend a solar 
heating system to family and friends (Pollard, 2008, p.58). This survey discovered that money saving is the main driver for installing a solar water heating system, and more information should be provided in the promotion of these systems to the public.

Currently, a solar water heating system installation typically costs between $\$ 4000$ and $\$ 8000$ (EECA, 2007, p.1). At current energy prices, they can pay for themselves within 10 to 15 years. It will cut about $2200 \mathrm{KWh}$ from annual electricity use, and provide annual savings of $\$ 350$ - $\$ 450$ (EECA, 2007). 


\section{Appliances and Lighting Retrofit}

House hold appliances (white goods, such as fridge, oven, washing machine, and other items such as televisions, DVD player and toaster etc) and lighting system in an average New Zealand house can account for $31 \%$ of energy use (Isaacs et al, 2006, p.31). In many area of the house there has been a significant increase in energy consuming equipment. Therefore, any reduction in energy use related to appliances and lighting can have a significant impact in terms of cost to the householder and energy consumption. There are many potential opportunities for the energy saving retrofit for appliances and lighting section.

This study is focused on two parts of energy consumption: operational energy use and standby energy use.

Operational energy is defined as the energy consumption of appliances during the operating period. Standby energy is the power use of appliances in waiting mode, during which time they are not providing useful output but still consume energy.

\subsection{Category break down}

Household appliances energy retrofit is started with the electricity consumption breakdown of different appliance types. The HEEP study gave the monitored data as below:

\begin{tabular}{|c|c|c|}
\hline Appliances Type & $\begin{array}{c}\text { Average } \\
\text { (KWH/year/household) }\end{array}$ & $\mathbf{\%}$ \\
\hline Refrigeration & 1119 & $28 \%$ \\
\hline Lighting(hardwired) & 915 & $23 \%$ \\
\hline Range(hardwired) & 497 & $12 \%$ \\
\hline Entertainment & 364 & $9 \%$ \\
\hline Computer/Games & 227 & $6 \%$ \\
\hline Electric jug & 152 & $4 \%$ \\
\hline
\end{tabular}




\begin{tabular}{|c|c|c|}
\hline Spa pools & 123 & $3 \%$ \\
\hline Other Climate Control & 119 & $3 \%$ \\
\hline Dryer & 119 & $3 \%$ \\
\hline Dishwasher & 107 & $3 \%$ \\
\hline Large miscellaneous & 73 & $2 \%$ \\
\hline Washing machine & 63 & $2 \%$ \\
\hline Microwave & 62 & $2 \%$ \\
\hline Other cooking & 52 & $1 \%$ \\
\hline Small Miscellaneous & 40 & $1 \%$ \\
\hline Total & 4032 & $100 \%$ \\
\hline
\end{tabular}

Table 34: Average Appliance Electricity Consumption Per Household.

(Source: HEEP year 10 Report, Isaacs et al, 2006, p.23)

This is the consumption for each appliance type on an average house basis is. Refrigeration is not surprising taking about $28 \%$ of the electricity use of the whole appliances group. Normally this is the only cooling energy use and mainly for food conservation in the house. This is followed by lighting energy use, $5 \%$ less of energy use than fridge and freezer. $364 \mathrm{KWh}$ electricity is accounted for by the entertainment group, which includes all TVs, DVDs and stereo etc. If computers are counted as part of entertainment, the electricity consumption becomes larger than that of the cooking range, at $15 \%$ of the total. Monitored electricity consumption result of spa pools was higher than single cooking appliances, such as microwave oven, and dishwasher.

This study will give some retrofit options of the main electricity consumption items like particularly refrigeration and lighting.

\subsection{Refrigeration}

Normally, house refrigeration is provided by the fridge and freezer, either separately or as one combined appliance. From Table 34, they are the biggest consumers of all household appliances, mainly because they operate all the time. For the common fridge models, there is a small built in freezer in the top 
layer. It is believed that the fridge and freezer combination model is more efficient than separate ones. One important thing for fridge selection is that the size of the fridge should fit neatly to the demand of the household. A big fridge will consume more electricity in ongoing running. This study compares three size fridge costs and energy savings. Base refrigeration electricity use was selected from the HEEP study.

\begin{tabular}{|c|c|c|c|}
\hline \multicolumn{4}{|c|}{ Refrigeration } \\
\hline \multicolumn{4}{|c|}{$1086 \mathrm{KWH} /$ year/household (HEEP monitored average result; Wellington) } \\
\hline Retrofit Solutions: & $\begin{array}{c}\text { Option_1 } \\
\text { Small Fridge }\end{array}$ & $\begin{array}{c}\text { Option_2 } \\
\text { Medium Fridge }\end{array}$ & $\begin{array}{l}\text { Option_3 } \\
\text { Big Fridge }\end{array}$ \\
\hline & \multicolumn{3}{|c|}{ Upgrade with } \\
\hline Model $^{(15)}$ & $\begin{array}{c}\text { Elba by Fisher \& } \\
\text { Paykel RF331T }\end{array}$ & $\begin{array}{c}\text { Elba by Fisher \& } \\
\text { Paykel RF381T }\end{array}$ & $\begin{array}{c}\text { Electrolux } \\
\text { EQE6007SA/SB }\end{array}$ \\
\hline Size & $329 \mathrm{~L}$ & $380 \mathrm{~L}$ & $600 \mathrm{~L}$ \\
\hline Price & $\$ 1,399$ & $\$ 1,649$ & $\$ 3,599$ \\
\hline Running Cost/Year & $\$ 70$ & $\$ 76$ & $\$ 115$ \\
\hline Energy Use & $333 \mathrm{KWh}$ & $362 \mathrm{KWh}$ & $548 \mathrm{KWh}$ \\
\hline Energy Saving per year & $\begin{array}{r}1086-333 \\
=753 \mathrm{KWh}\end{array}$ & $\begin{array}{l}1086-362 \\
=724 \mathrm{KWh}\end{array}$ & $\begin{array}{l}1086-548 \\
=571 \mathrm{KWh}\end{array}$ \\
\hline
\end{tabular}

Table 35: Refrigeration Retrofit Solutions Calculation

(Fridge Model cost data source: www.consumer.co.nz)

From Table 35, it can be seen that large size fridge costs more than double the small one. Also it uses $164 \%$ more energy than a small fridge. $786 \mathrm{KWh}$ of electricity can be saved by choosing a smaller size fridge on a yearly basis. Slightly less energy saving can also be made by a medium size fridge, $757 \mathrm{KWh} /$ year. It should be noted that these fridges are not small in the sense of

\footnotetext{
${ }^{15}$ Fridge model and price quoted from Consumer NZ.

http://www.consumer.org.nz/reports/fridge-freezers/we-recommend
} 
a fridge to fit under a kitchen bench top, they are full-height appliances.

Another factor affecting fridge energy use is the cooling temperature set point.

O'Donnell (2008, p.56) suggested that a reasonable temperature set point for fridge is $3-5^{\circ} \mathrm{C}$, and mentioned $5 \%$ more energy will be required for each $1^{\circ} \mathrm{C}$ drop in temperature.

One surprise finding of the HEEP study is that approximately $16 \%$ of refrigeration appliances were faulty (Isaacs et al, 2006, p. 82). Normally, it is not obvious to notice the problem, as the fridge still makes a noise and food might be kept cold, but the cabinet insulation can be degraded, the compressor coolant can leak, door seals can fail, or the thermostat controller has failed. Isaacs et al (2006, p. 82) also suggest the method to identify a faulty fridge is by monitoring whether the compressor is operating continually or not. Fridge compressor is supposed to work intermittently. Also, unexpectedly frozen food can be another sign to identify the problem.

It is believed that older fridges are more likely to be faulty. Therefore, energy saving by replacement of old fridges with new models will benefit from the improved energy efficiency of new appliances.

\subsection{Lighting}

Artificial lighting provides a wide variety of benefits in houses. It allows activities to be made without daylight and creates different interior lighting atmosphere to meet occupants' need. It is not hard to understand that different people have different lighting preferences for various indoor scenarios, such as light quality and quantity, which lead to different lighting energy requirements. In New Zealand, lighting in a typical house accounts for $8 \%$ of energy use (Isaacs et al, 2006, p.107). Good lighting system provides a pleasant and stimulating 
environment with minimum use of energy.

The principle of lighting design is that natural daylight should be integrated with artificial lighting. However, for house retrofit, building fabric geometry (including window opening position and dimension) is very much fixed. Therefore, for a particular house, daylight input is hard to modify, apart from installation of a skylight or light conducting tube. But, for the majority of cases, artificial lighting is the main target for energy saving and much easier to be upgraded.

Traditional light bulbs and halogen lamps are incandescent, and their light is produced by rising in temperature of the filament. This type of light bulb is widely used in the existing houses, for the reasons of original lighting fittings and bulb availability when the house was built. Fluorescent tubes and compact fluorescent (CF) lamps use the luminescence produced by the powder-coated lining of the tubes (Salomon and Bedel, 2003, p.77). However, these two types of lamps have different energy efficiency, O'Donnell (2008, p.50) pointed out that a $75 \mathrm{~W}$ incandescent bulb produces the same light output as a $15 \mathrm{~W}$ compact fluorescent lamp. This is because an incandescent light bulb turns a lot of electricity into heat, and only a small portion of energy is converted to light.

The following table gives an assumption of incandescent light bulb numbers for each room, and the result of calculating the energy saving by replacement with high efficiency light bulbs. 


\section{Lighting(hardwired)}

760KWH/year/household (HEEP monitored average result; Wellington)

\begin{tabular}{|c|c|c|}
\hline Retrofit Solutions: & \multicolumn{2}{|c|}{ Replace with Energy Efficient bulbs } \\
\hline Assumptions & Number & Hours lights on per day \\
\hline Bathroom & 2 & 2 \\
\hline Bedrooms & 12 & 3 \\
\hline Dining room & 6 & 3 \\
\hline Hallways & 4 & 2 \\
\hline Kitchen & 4 & 3 \\
\hline Lounge & 2 & 3 \\
\hline Total & 30 & \\
\hline $\begin{array}{l}\text { Replace with } \\
\text { (Bulb Model) }\end{array}$ & \multicolumn{2}{|c|}{ 20W, Philips Tornado Warm White ${ }^{(16)}$} \\
\hline Price & \multicolumn{2}{|c|}{$\$ 7.48$ each $\times 30=\$ 224.4$} \\
\hline Running Cost/Year & $\$ 113.96$ & Energy Use/Year: 570KWh \\
\hline
\end{tabular}

Table 36: Lighting Retrofit Cost Calculation

From the result of the calculation, it can be seen that a total of $190 \mathrm{KWh}$ can be saved by upgrading with low energy bulbs. The cost benefit return cycle is about two years.

Lighting energy saving is also depending on occupants' behaviour. Turning off light when it is not needed or avoiding over-lighting is the simple measure to avoid energy waste. Also, it should be recommended using lighting control fittings, such as timer, daylight sensor and dimmer, to minimise lighting power use, although many types of compact fluorescent lamps cannot be used with dimmers.

\subsection{Range and other appliances}

Table 34 showed that apart from refrigeration and lighting, the range and other appliances totally together account for $49 \%$ of house appliances electricity use.

\footnotetext{
${ }^{16}$ Light bulb price source: New Zealand CONSUMER website, http://www.consumer.org.nz/reports/energy-efficient-lighting/we-recommend
} 
This group includes appliances of home entertainment, cooking and miscellaneous. Energy consumption of this group is dependent on the two factors: energy efficiency of each particular item and the way householders use them. This section will discuss retrofit solutions for this group appliances.

With new technology development, more variety of electrical appliances will be invented and adopted at home. House occupants want the service that energy can provide. It is not easily noticed the higher energy intensity these appliances would cause. Therefore, with people's pursuit of higher living standard, more electrical appliances will be adopted in the home. The increased power consumption of household appliances could be a trend for the near future.

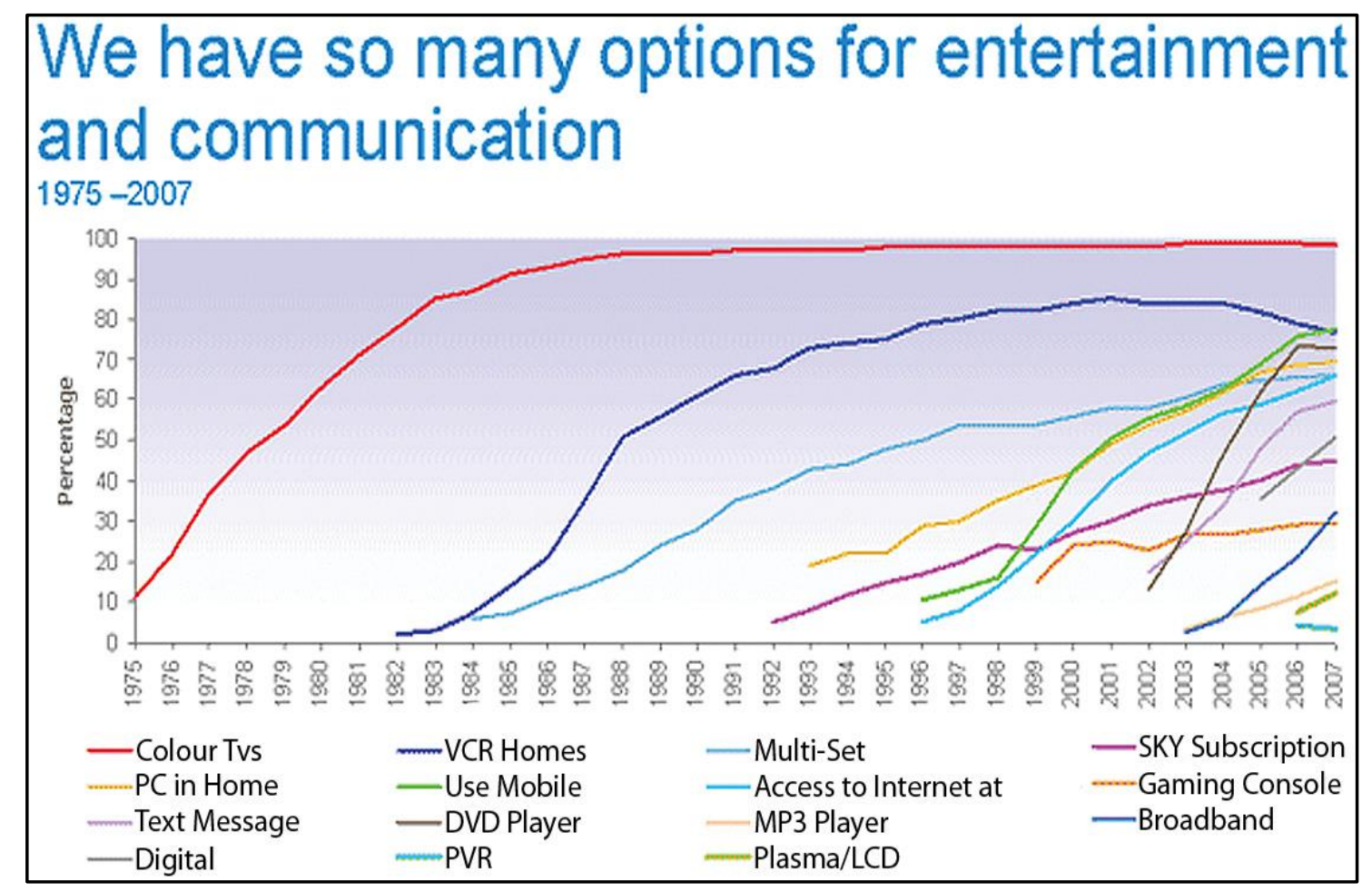

Figure 23: The Changing Home Environment.

(Source: Nielsen Media Research NZ, 2009)

Figure 23 shows that for the last 18 years there were great changes to the communication and entertainment in the home. New technology has provided a wider range of TV viewing options. For last two decades, mobile phone, SKY 
decoder and gaming console have been becoming more and more popular in New Zealand homes. Only the VCR showed a decreasing trend during the last ten years. Television has remained in remarkably the dominant position. Young and single professionals are more likely to have new technology appliances and spend a significant amount of leisure time using them (Owen P, 2006, p.11).

Household appliances development is based on technology innovation. Normally, technological innovation is created to meet particular needs. Nowadays, different kinds of house work have generated different ideas of how to do them with more ease. For example, the dishwasher, which makes dish washing much easier, also increases the consumption of both electricity and hot water, compared with traditional ways of dish washing.

\subsection{Home appliances new trend}

Owen (2006, p.3) mentioned that the consumer electronics sector is currently the most significant growth area of electricity consumption in the home. The study also predicted that by 2020 , entertainment, computers and gadgets will use an extraordinary 45 per cent of electricity power in the homes of the UK.

Mithraratne et al (2007, p.205) pointed out that appliances are more likely replaced frequently, compared with hot water systems, which may be replaced once or twice over the lifetime of a house. This is probably for the reason of fashion and expensive repair cost.

It can be really a conflict between low energy consumption and new technology development of household appliances. Technical innovations provide more energy efficient appliances. However, the way people operate electrical appliances is another factor, which affects energy consumption. Some new model TVs are multi functional and can be used for listening to digital radio 
programmes. Compare to traditional radio, which is only a few watts, that makes some unnecessary extra power demand. Owen (2006, p.23) pointed out that 40 percent of people in UK already use this energy intensive way for radio listening.

Householders should be encouraged to give up energy intensive habits for more energy conscious activities. It means making the best possible use of energy, rather than simply continuing to consume more and more. It should become a habit to track down wasted energy and eliminate it by using available energy more efficiently and, wherever possible, persist with renewable energy sources. Eliminating energy waste is not necessarily cutting down peoples' living standard. Only a small positive action can make big difference. For instance, hanging washing outdoors rather than using the drier will not only help to reduce electricity use, but also benefit from sunshine UV for killing bacteria on the washing and cost nothing.

\subsection{Standby energy}

Many home appliances consume energy, not only in use, but also when the appliance is switched off and in standby mode when it is waiting to be used. It is easy to leave electrical appliances switched on 24 hours a day, 7 days a week. Standby functions tend to be used more frequently than the 'off' button.

Isaacs (et al, 2006, p.58) gave the definition of standby power and baseload power as below:

"The standby power is defined as the average power measured in standby mode. The baseload power of a house is defined as the typical lowest power consumption of the entire house when there is no active occupant demand and all cycling appliances (e.g. refrigeration) are in off-cycle. It includes the standby power of appliances (e.g. microwave ovens, VCRs, multiple TVs, video games, dishwashers 
etc), plus any appliances that operate continuously" Isaacs et al (2006, p.58) mentioned one study done by Sandberg E (1994) with the conclusion that some old model appliances even use more energy in standby mode than in operation. There is one thing that should be emphasized, that because the small load of standby power is continuing consumption on a long time basis, the count up of standby energy can be significant, compared with a large load turned on for a comparatively short time. This can be described as the relationship between Small $\times$ Big and Big $\times$ Small. For example, a TV set could be turned on for two hours and kept on standby mode for 22 hours during a day.

In New Zealand, on average $57 \mathrm{~W}$ is continuously used by standby power per household (Isaacs et al, 2006, p.63). Under the current electricity cost of 25 cents per $\mathrm{KWh}$, this means approximately $\$ 125$ is charged per year on a household electricity bill.

According to one New Zealand study, VCR, Television and Stereo are the three highest standby energy appliances (Isaacs et al, 2006, p.63). In the UK, Owen $P(2006, p .27)$ discovered that the games consoles energy consumption there is not much different between 'idle' mode and when the console is actively being used.

It is possible for an appliance to use more electricity in standby that it uses for its real purpose, such as a VCR, if it is used once a week or even a month. An increasing habit that people are taking is to charge mobile phones each night even if not necessary (Owen, 2006, p.8).

Solution of standby power waste is quite simple: fully turn it off when not in need. 


\subsection{Appliances retrofit recommendations}

From the exploration and calculation of the previous section, some appliances recommendations can be made:

- Check the condition of fridge, replace with energy efficient one if necessary.

- Energy Rating labels are good indicator for energy efficiency of the new appliances. The labels contain a star rating from 1 to 5 and show the annual energy consumption in KWh. The Energy Efficiency and Conservation Authority (EECA) suggest that each extra star indicates $10 \%$ saving in power use (McDonald, 2008, p.55).

- Upgrade lighting system with energy efficient light bulbs. Turn light off when it is not in need.

- Try to avoid energy intense use habit of home electric appliances

- Switch off electric appliances when not needed. This can save $\$ 125$ cost on standby power for an average house.

- All household appliances need to be selected to be as energy efficient as possible, and users also need to consider behaviour in using appliances.

- It is possible to introduce small electricity metering equipment which could help occupants facilitate managing energy demand of appliances. 


\section{Findings and Results}

The previous sections discussed and tested house retrofit solutions individually. This section will compare all results, which were collected from previous chapters.

\subsection{Overall comparison of the three retrofit categories}

House retrofit work can be judged by the benefits of thermal comfort improvement and better energy efficiency provided by the money spent. Cost has always been the first issue for many house owners as the retrofit cost may well limit what house work can be achieved, and affect how good the eventual building performance is.

From the results of investigation and calculation of the previous house retrofit chapters, it was found that different retrofit solutions can provide different benefits in either energy conservation or thermal comfort. This section will present a cross comparison for all of the retrofit options of this study.

For the typical house used in the simulations, it costs $\$ 30257$ to install optimum level insulation with double glazing and air infiltration control. After this insulation retrofit, four portable electric heaters would be sufficient to provide comfortable indoor temperatures. This heating solution will cost $\$ 600$. Hot water heating system retrofit costs $\$ 4000-8000$ with the upgrading to a solar water heating system. The fridge and lighting system cost \$1399 and \$224 respectively for the appliances retrofit category. 
as the HEEP monitored data. The reason for this difference is that the HEEP monitored house could be only partially insulated and heated intermittently for part of the house, or even heated below the comfortable temperature level. The optimum level insulation house thermal simulation showed that 24 hours comfortable temperatures could be achieved with low space heating requirement. This means, based on the HEEP monitored average data, a $\$ 38480$ house retrofit investment will achieve annually an energy saving of 5986KWh. If the retrofit starts from an uninsulated house, a bigger energy saving could be made of $8,159 \mathrm{KWh}$, which is equal to a $\$ 2,039$ saving on the power bill per year. Simple payback based on this is 19 years. But if the electricity price doubles in 20 years, the annual saving will be $\$ 4,078$, and simple payback is just 9.4 years.

The calculation of energy saving to retrofit cost ratio $(\mathrm{KWh} / \$)$ presents a useful picture of power saving efficacy. Lighting system retrofit has the highest ratio of $0.85 \mathrm{KWh} / \$$, followed by fridge, solar water heating system and space heating. This means, solely from the purpose of energy saving, lighting and appliances upgrading should be carried out prior to other retrofit options in terms of efficacy of money invested. However, for those retrofit works (water heating and space heating) with low $\mathrm{KWh} / \$$ ratio, the annual absolute energy saving is much more than that made by appliances and lighting retrofit.

Furthermore, if these retrofit investments are made through a bank loan, the repayment period and amount will be as shown in Table 38: 


\begin{tabular}{|c|c|c|c|c|c|}
\hline \multicolumn{6}{|c|}{ Retrofit Investment and Saving Calculation } \\
\hline Retrofit & Description & Cost & $\begin{array}{c}20 \text { years } \\
\text { total loan } \\
\text { repayment }^{1}\end{array}$ & $\begin{array}{l}\text { Annual } \\
\text { Saving } \\
\text { (KWh) }\end{array}$ & $\begin{array}{c}20 \text { years } \\
\text { total saving }\end{array}$ \\
\hline $\begin{array}{l}\text { Space } \\
\text { Heating }\end{array}$ & $\begin{array}{l}\text { Building } \\
\text { fabric retrofit } \\
\text { with } \\
\text { Heating } \\
\text { upgrading }\end{array}$ & $\$ 30,857$ & $\$ 53,020$ & 4,327 & $\$ 30,592$ \\
\hline $\begin{array}{l}\text { Hot water } \\
\text { Heating }\end{array}$ & $\begin{array}{c}\text { Solar hot } \\
\text { water system }\end{array}$ & $\$ 7,000$ & $\$ 12,028$ & 2,889 & $\$ 20,425$ \\
\hline Appliances & Fridge & $\$ 1,399$ & $\$ 2,404$ & 753 & $\$ 5,324$ \\
\hline & lighting & $\$ 224$ & $\$ 385$ & 190 & $\$ 1,343$ \\
\hline Total & & $\$ 39,480$ & $\$ 67,836$ & 8,159 & $\$ 57,683$ \\
\hline \multicolumn{6}{|c|}{$\begin{array}{l}\text { Note: } \\
{ }^{1} \text { Assume interest rate is } 6 \% \text { and repay period is } 20 \text { years for bank loan. } \\
{ }^{2} \text { Annual Energy Saving_2 (from Table } 37, p .134 \text { ) was chosen for } \\
\text { calculation. Assume electricity price is increased by } 3.5 \% \text { every year } \\
\text { (Figure } 2, p .25) . \text { Current price is } \$ 0.25 / \mathrm{KWh} .\end{array}$} \\
\hline
\end{tabular}

Table 38: Retrofit Investment and Saving Calculation

As Table 38 presents, for a long-term view, the initial house retrofit cost can nearly be recovered by 20 years energy saving.

If the initial cost is loaned by the bank, apart from full insulation upgrading, other retrofit costs still can be covered. Currently, the New Zealand government Heat Smart programme subsidizes $33 \%$ of the total insulation cost up to $\$ 1,300$ (EECA, 2009A) and $\$ 1,000$ for a solar water heating system (EECA, 2009B). If this programme could subsidize $33 \%$ of total house full insulation retrofit cost $(\$ 30,857), \quad \$ 10,286$ and $\$ 20,571$ will be covered by government and householder respectively. If $\$ 20,571$ is loaned from bank, the 20 years total repayment will be $\$ 35,335$, plus the retrofit cost of hot water heating and appliances, totalling $\$ 50,152$. Twenty years total energy saving is $\$ 57,683$, which can cover the retrofit cost. 
So, if the $30 \%$ government subsidy is applied to the full insulation retrofit, it is cheap enough for the householders to make it worth doing.

If $\$ 1$ spent on insulation retrofit saves $\$ 2$ in the health budget (estimated by Howden-Chapman et al, 2004, p.22), $\$ 30,857$ upgrading cost saves $\$ 61,714$ in the health budget. On this basis, taking $\$ 10,286$ out of the national health budget for a subsidy to make insulation retrofit affordable still leaves $\$ 51,428$ saving to be spent in the health budget somewhere else. 


\section{Conclusions and Discussion}

Building envelope insulation retrofit allows for making significant improvements in indoor comfort and health. This study has discovered that the combined building element retrofit solution is able to improve indoor temperature by $6.3^{\circ} \mathrm{C}$ (annual average increase) for mean air temperature and $7^{\circ} \mathrm{C}$ for mean radiant temperature. The actual thermal comfort improvement should be higher than observed mean air temperature increase, due to the combination effect of mean radiant temperature and mean air temperature. Required heating energy can be saved to the amount of $4,327 \mathrm{KWh}$ per year for the 24 hours heating scheme and $1,723 \mathrm{KWh}$ for the intermittent heating scheme.

The key option found to increase comfortable temperature hours significantly and make energy saving was the high level insulation retrofit, double glazing window retrofit with low emissivity panes, and sufficient air tightness control. By adopting this retrofit option, comfortable temperatures and energy efficient targets can be achieved based on existing dwellings. If Building Code level of insulation is only applied to partial building elements, such as ceiling and floor, it will be hard to make significant improvement in both thermal comfort and energy saving. Heating system retrofit will also be involved in combination with this method. The simulation results also presented that, after high level insulation was installed for the existing house, the space heating requirement dropped to such a low level that it can be provided by very cheap and simple heating equipment.

Suggestions are made for hot water heating system and appliances retrofit. Conventional hot water cylinder is suggested to be replaced with solar heating system. For appliances retrofit, this study gives some proposed upgrading 
options for fridge and lighting. Actually, big energy saving margin still exist for other miscellaneous appliances. This part of energy consumption is very much depending on occupants' selection and use pattern.

The calculation of energy saving to investment ratio found that lighting and appliances retrofit showed a relatively higher efficacy. Hot water system retrofit and space heating retrofit have bigger total annual energy savings, but the cost benefit cycle is longer than other house upgrading options. From a benefit point of view, only space heating retrofit can make an improvement in thermal comfort. From the results of the cost benefit study, it can be concluded that there are primarily two important factors which affect building retrofit efficacy: power cost and insulation material cost. Both of them act as a strong lever to modify retrofit efficacy pattern. As discussed before, electricity price has shown an increasing trend for the last three decades. If the power cost keeps developing in this tendency, house retrofit work will be more beneficial, as more heating energy cost will be saved and fewer householders will be risking fuel poverty. On the other hand, if insulation cost decreases to a reasonably low level, this will cut down the return cycle of retrofit investment. Regarding double glazing retrofit, the efficacy and cost depend on the design solutions. As mentioned before, replacement with new window units can be much cheaper than fitting more glass panes in the existing window frame. Technology innovation may offer some new materials and designs for double glazing retrofit. Currently, with the newly released Building Code, more and more new houses need to have double glazed windows. This new marketing demand will stimulate massive production of double glazed window units. Adopting new window units with better air tightness for existing house retrofit could become more affordable. 
This study investigated New Zealand house stock and defined a typical house model for retrofit efficacy testing and analysis. In practice, not all of the building elements can be retrofitted due to the limitations of access and owners' investment shortage. For the houses with feasibility for insulation retrofit, it is possible to achieve better house thermal performance and more benefit in occupants' health. It is suggested government subsidy policy be revised to cover the cost of full insulation retrofit.

This research result is based on some reasonable assumptions, and it is believed that, for some common existing house types, the results can be representative and indicate the retrofit efficacy from a general point of view. The outcome of this research can be also applied to some other types of New Zealand existing houses.

As mentioned in chapter 2.1, this study will answer the following questions:
A. Why is the current New Zealand house insulation retrofit efficacy low?
B. What is the possible optimal efficacy of building element insulation retrofit?
C. How is thermal comfort traded off by energy saving after retrofit?
D. How to improve the efficacy of hot water heating system retrofit?
E. How to improve the efficacy of appliances and lighting retrofit?
$F$. What is the cost effectiveness comparison between space heating retrofit, hot water heating retrofit, and appliances retrofit?

The answers to the research questions are as follows:

\section{A. Why is the current New Zealand house insulation retrofit efficacy low?}

New Zealand house stock is dominated by light weight structures which do not retain heat inside of the building. Some house roofs and floors are accessible, which gives rise to the chance to install insulation. However, one of the main reasons for low retrofit efficacy is insulation retrofit is often only 
applied to part of the building elements, such as ceiling and floor. This commonly adopted strategy makes other building elements, such as walls and windows, into relatively weak points in terms of heat loss. In this study the program simulation has shown that overall insulation and glazing retrofit with sufficient draught control makes a significant difference to house thermal performance and can cut space heating requirement to a very low level. Therefore, based on the New Zealand house characteristics, basic level insulation applied to part of the building fabric is not sufficient to reach a reasonably high efficacy in either energy saving or thermal comfort improvement.

B. What is the possible optimal efficacy of building element insulation retrofit?

By comparing the retrofit work already carried out in New Zealand and the retrofit options simulation analysis of this study, the optimal efficacy can be achieved by applying maximum level insulation material to all building elements. Owing to the low level of window R-value, both building element insulation retrofit and windows upgrading should be considered to ensure the optimal thermal performance.

\section{c. How is thermal comfort traded off by energy saving after retrofit?}

In theory, after insulation retrofit, only a small amount of energy is required to maintain a comfortable temperature, which can be provided with portable electric heaters. Also, the way occupants operate space heating plays a big role in energy use and indoor temperature. Generally, after insulation retrofit is applied to a building, it is estimated that the trade-off of energy use and thermal comfort may have three possibilities: reducing the energy input to 
keep the same degree of temperature, improving thermal comfort with the same energy requirement, or somewhere in between these two patterns. However, in the insulation simulations of this study, 24 hour heating was modelled to ensure that results would be likely to represent the largest heating load that might occur.

\section{How to improve the efficacy of hot water heating system retrofit?}

Due to the high energy efficiency of a solar heating system, this is recommended to replace the basic electric hot water cylinder. Simple measures can also be carried out to improve the electric hot water cylinder, such as installing cylinder insulation wrapping, using low pressure taps and shower heads, and reducing the temperature set point (to $55^{\circ} \mathrm{C}$ ).

\section{E. How to improve the efficacy of appliances and lighting retrofit?}

The basic approach is to replace appliances and light bulbs with highly energy efficient ones. This study discovered that lighting retrofit has higher cost effectiveness than other retrofit options. So, this should be considered as a priority. Also, care needs to be taken in standby power consumption; users need to fully turn off appliances when not in need. This shows the role that use behaviour can play in improving energy performance for appliances.

\section{F. What is the cost effectiveness between space heating retrofit, hot water} heating retrofit, and appliances retrofit?

Compared with appliances retrofit, cost effectiveness of space heating retrofit and hot water heating retrofit is relatively low. Although the cost benefit cycle is longer, space heating and water heating retrofit can make bigger overall energy savings. 


\section{Summary and Implications of Conclusions:}

House retrofit should be considered and carried out with a holistic approach with all of the elements being considered. To achieve a higher level of house thermal performance and more health benefit for occupants, a combination of full insulation retrofit of building elements (ceiling, wall and floor) with double glazing and sufficient draught control is highly recommended. Space heating equipment upgrading needs to be integrated with the building envelope retrofit. Upgrading of hot water heating, appliances and lighting is also recommended as part of the house retrofit. In addition, space heating retrofit and hot water heating retrofit should be considered for long term cost effectiveness, while appliances and lighting retrofit can achieve higher efficacy with short cost return cycle. 


\section{Future Research}

To guide some further research on energy-efficient and thermal comfort retrofit solutions, some comments are given as below.

High R-value thermal insulation materials could have an important role in retrofit solutions, especially for the limited installation spaces, such as space in-between timber wall studs and gaps in-between timber floor joists, etc. Cost and benefits of such materials could be studied.

Low cost retrofit construction details may need to be investigated and created, especially for double glazing adoption for existing window frames.

Retrofit solution cost benefit greatly depends on two factors, the cost of insulation material and the cost of power. More detailed analysis is needed on the relationship between these.

Further research is necessary to explore energy consumption of home entertainment systems and appliances which have an increasing trend. The relative investigation could be carried out for the near future.

More work is needed to investigate the relationship between insulation level and indoor humidity level, and how humidity affects mean radiant temperature and thermal comfort.

Full insulation retrofit house samples with intensive site monitoring are needed for real case studies of buildings in use. 


\section{REFERENCES:}

Addington, M. and Schodek, D. (2005). Smart Materials and New Technologies, For the Architecture and Design Professions. Architectural Press: Amsterdam, Boston.

AIRFOAM. (2010). Technical Information.

http://www.airfoam.co.nz/technical.php (Viewed on 10 March, 2010).

Allen, E. (2005). How Buildings Work-The Natural Order Of Architecture Third Edition. Oxford University Press: Oxford; New York.

Amitrano, LJ, Kirk, NR, Page, IC. (2006). Market Segmentation of New Zealand's Housing Stock. Beacon Pathway Ltd, New Zealand.

Bassett, M. (2001). Naturally Ventilated Houses In New Zealand Simplified Air Infiltration Prediction. BRANZ Conference Paper No. 90. Presented at the CIB World Building Congress, Wellington, New Zealand. April 2001.

Bassett, M., R. (1992). House Airtightness Variation with Age. BRANZ Conference Paper No.19. From the $10^{\text {th }}$ International PLEA Conference "Passive and LOW Energy Architecture", Auckland, New Zealand. 19-22 August 1992.

Bassett, M., R. (1992). Ventilation trends in New Zealand Housing. Conference paper from the Public health Association of New Zealand "Access to Health" conference, May 1992, Lincoln, New Zealand.

Bassett, M., R. (1996). Conference Paper: A Practical Study of Retrofit Airtightening Old Houses for Energy Efficiency. BRANZ Conference Paper No.27. Presented at the IPENZ Annual Conference, 9-13 February, 1996, Dunedin, New Zealand. 
Boardman B. (1994). Strategies for action. In: T.A. (Ed.), Domestic Energy and Affordable Warmth, E \& F N SPON: London, pp. 81-96.

Boardman, B. (1991). Fuel Poverty: From Cold Homes to Affordable Warmth. Belhaven Press, London.

BRANZ. (1995). Bulletin No.334, Reducing Heat Loss From Existing Houses. BRANZ, Judgeford, Porirua, New Zealand.

Bunting, D. (1994). New Zealand Home Renovation. Doubleday: New Zealand.

Burns, P. (1992). Building Solar gain Modelling, In: Passive Solar Buildings, Edited by Balcomb J. Douglas. Massachusetts Institute of Technology. pp. 39-111.

Chapman, R., Howden-Chapman, P. and O'Dea, D. (2004). A Cost-Benefit Evaluation Of Housing Insulation: Results From The New Zealand 'Housing, Insulation And Health' Study. Research paper from Wellington School of Medicine and Health Sciences, University of Otago.

Clark, S.J., Jones, M., Page, I.C. (2005). New Zealand 2005 House Condition Survey. BRANZ Ltd Study Report No. 142 (2005), BRANZ, Judgeford, Porirua, New Zealand.

CONSUMER NZ. (2010). Oil-filled heaters. http://www.consumer.org.nz/products/Oil-filled-heaters/DeLonghiDL2401TF/39990 (Viewed on 13 March, 2010).

Cowan, H. and Smith, P. (2004). Dictionary of Architectural and Building Technology Fourth edition. SPON Press: London and New York.

Crawley, D., Lawrie, L., Winkelmann, F., Buhl, Huang, Y., Pedersen, C., Strand, R., Liesen, R., Fisher, D., Witte, M. and Glazer, J. (2001). EnergyPlus: 
creating a new-generation building energy simulation program.

Energy and Buildings, Volume 33, Issue 4, April 2001, Pages 319331

Crawley, D., Hand, J., Kummert, M. and Griffith, B. (2005). Contrasting the Capabilities of Building Energy Performance Simulation Programs. in Proceedings of Building Simulation 2005, 15-18 August 2005, Montreal, Quebec, Canada. IBPSA.

Cunningham, M., Roberts, P. and Hearfield, M. (2001). Changes in Indoor Climate And Microclimate of a New Zealand Bungalow after a TwoStage Insulation Retrofit. BRANZ Conference Paper No. 86.

Presented at the CIB World Building Congress, Wellington, New Zealand. 8-11 April 2001.

Cunningham, M. (2008). Warm, Dry Houses are healthier. BUILD October/November,2008. Page59.

Davies, N. and Jokiniemi, E., 2008, Dictionary of Architecture and Building Construction, First Edition 2008. Architectural Press: AMSTERDAM, BOSTON

Department of Building and Housing. (2007A). Compliance Document for New Zealand Building Code Energy Efficiency Clause H1 - Third Edition. Department of Building and Housing, Wellington.

Department of Building and Housing. (2007B). Compliance Document for New Zealand Building Code Clause G12 Water Supplies - Third Edition. Department of Building and Housing, Wellington.

Department of Building and Housing. (2008). Stay Warm in An Energy Efficient Home. 
http://www.sustainableliving.org.nz/pdf/energy_insulation_action. pdf (Viewed on 12 November, 2009).

Department of Statistics. (1973). Report on The Survey Of Household Electricity Consumption 1971-1972. Department of Statistics, Wellington, New Zealand.

Donn, M. and Thomas, G. (2001). Designing Comfortable Homes: Guidelines On The Use Of Glass, Mass And Insulation For Energy Efficiency. Cement \& Concrete Association of New Zealand: Wellington.

Duggan, J. (2004). A Study of Renovation Practice In Housing New Zealand Houses. Report by Winstone Wallboards Ltd, Auckland, New Zealand.

Easton, L., Pollard, A., And Jaques, R. (2008). Beacon Now Homes And Now Home Renovations: Transforming New Zealand's Housing Stock. Report for Beacon Pathway, Auckland, New Zealand.

EECA. (2009A). Funding For Insulation And Clean, Efficient Heating. http://www.energywise.govt.nz/funding-available/insulation-andclean-heating (Viewed on 10 February, 2010).

EECA. (2009B). Funding For Solar Water Heating. http://www.energywise.govt.nz/funding-available/solar-and-heatpump-water-heating-funding/apply-for-a-solar-water-heatinggrant (Viewed on 10 February, 2010).

EECA. (2010). Wall Insulation, http://www.energywise.govt.nz/how-to-beenergy-efficient/your-house/insulation/wall-insulation (Viewed on $14 \mathrm{Feb}, 2010)$.

EECA. (1997). Solar Water Heating, Energy-Wise Renewables - 1. Energy Efficiency and Conservation Authority, New Zealand. 
EECA. (2006). Solar Water Heating Guidebook-- A technical guide for building industry professional. Energy Efficiency and Conservation Authority, New Zealand.

EECA. (2007). Consumer Solar Water Heating Guide. Energy Efficiency and Conservation Authority, New Zealand.

Elias, A. (2008). Energy efficiency in New Zealand's residential sector: A systemic analysis. Energy Policy 36 (2008) 3278- 3285

Evans, M. (1999). Tropical Design, In: Metric Handbook Planning And Design Data, Second Edition. Edited By David Adler. Architectural Press. pp.555-565

Fanger, P. O. (1970). Thermal Comfort, Danish Technical Press, Copenhagen.

French, L. (2008). Active Cooling and Heat Pump Use In New Zealand - Survey Results. BRANZ Study Report No.SR186. BRANZ, Judgeford, Porirua, New Zealand.

French, L., Camilleri, M, and Isaacs, N. (2008). Influences On Summer Indoor Temperatures In A Representative Sample Of New Zealand Houses. Conference Paper Number131 2007. Presented at the XXXVth International Association of Housing Science (IAHS) World Congress on Housing Science, Melbourne 4-6 Sep 2007.

French, L., Isaacs, N., and Pollard, A. (2006). Winter Temperatures in New Zealand Houses. Conference Paper No.123. Presented at the 2006 Windsor Conference 'Comfort and Energy Use in Buildings-Getting Then Right', Cumberland lodge, Windsor, United Kingdom (27-30 April 2006).

Hall, F. and Greeno, R. (2007). Building Services Handbook. Fourth edition. Butterworth-Heinemann: Amsterdam; Boston 
Harris, G., Gales, S., Allan, R. (1993). Promoting the Market for Energy Efficiency. Energy and Resources Division of Ministry of Commerce, Institute of Economic Research.

Hindley, D. and Pringle, T. (2009). Determining The Industry Need For A Retrofit And Renovation Information Resource. BRANZ Study Report No.SR203 (2009). BRANZ, Judgeford, Porirua, New Zealand.

Hoppe, P. (1988). Comfort Requirements In Indoor Climate. Energy and Buildings, Volume 11, Issues 1-3, 22 March 1988, Pages 249-257

Howden-Chapman, P., Viggers, H., Chapman, R. and O'Dea, D. (2009). Warm Homes: Drivers of The Demand For Heating In The Residential Sector In New Zealand. Energy Policy, Volume 37, Issue 9, September 2009, Pages 3387-3399

HPAC Engineering. (2010) Optimizing the Performance of Radiant Heating Systems. http://hpac.com/heating/optimizing-the-performance-ofradiant-heating-systems/index.html (Viewed on 19 Feb, 2010).

Humphreys, M. (1997). An Adaptive Approach to Thermal Comfort Criteria, In: Naturally Ventilated Buildings: Buildings for the senses, the economy and society. Edited by Clements-Croome, D. E \& FN SPON: London. pp.129-139

Humphries, M. A. and Nicol, J. F. (2002). The Validity Of ISO-PMV For Predicting Comfort Votes In Every-Day Thermal Environments. Energy and Buildings Volume 34, Issue 6, July 2002, Pages 667-684

IEA (International Energy Agency). (2009). Towards Net Zero Energy Solar Buildings, ECBCS / SHC Project Factsheet. Annex 52 / Task 40. Published by AECOM on behalf of IEA ECBCS@ AECOM Ltd 2009

Isaacs, N. (2007). Thermal Insulation, BUILD, October/November 2007, 
Page110-111.

Isaacs, N. and Trethowen, H. A. (1985). A Survey of House Insulation. BRANZ Research Report No.R46. BRANZ, Judgeford, Porirua, New Zealand.

Isaacs, N. (1998). Poverty and Comfort? BRANZ Conference Paper NO.59.

Presented at the Fourth National Food Bank Conference, Wellington, 13 November, 1998.

Isaacs, N., Amitrano, L., Camilleri, M., Pollard, A., Stoecklein, A. (2003). Energy Use in New Zealand Households, Report on the Year 7 analysis for the Household Energy End-Use Project (HEEP). BRANZ, Judgeford, Porirua, New Zealand.

Isaacs, N., Camilleri, M., French, L., Pollard, A., Smith-Saville, K., Fraser, R. and Rossouw, P. (2005). Energy Use in New Zealand Households. Report on the year 9 Analysis for the Household Energy End-use Project [HEEP]. BRANZ, Judgeford, Porirua, New Zealand.

Isaacs, N., Camilleri, M., French, L., Pollard, A., Smith-Saville, K., Fraser, R., Rossouw, P. and John, J. (2006). Energy Use in New Zealand Households. Report on the year 10 Analysis for the Household Energy End-use Project [HEEP]. BRANZ, Judgeford, Porirua, New Zealand.

Lloyd, B. and Maria, C. (2006). Monitoring of Energy Monitoring Efficiency Upgrades in State Houses in southern New Zealand. Physics Department, University of Otago, Dunedin, New Zealand.

Lloyd, B. and Maria, C. (2009). Retrofit Interventions To Enable Healthy Living Conditions In Existing NZ Houses. Physics Department, University of Otago, Dunedin, New Zealand.

Lloyd, B. (2006). Fuel poverty in New Zealand. Social Policy Journal of New 
Zealand, 142-155.

Lloyd, B., Bishop, T., and Callau, M. (2007). Retrofit Alternatives for State Houses in Cold Regions of New Zealand-Report 2. A research project by the Energy Management Group, Physics Department, University of Otago Dunedin, New Zealand.

MAGICSEAL. (2007). MagicSeal Secondary Double Glazing for Thermal and Acoustic insulation of Existing Windows. Magic Seal.

McChesney, I., Cox-Smith, I., and Amitrano, L. (2008). Thermal Insulation in New Zealand Homes: A Status Report. Report from Beacon Pathway Ltd, Auckland, New Zealand.

Milne, G., Boardman, B. (2000). Making Cold Homes Warmer: The Effect of Energy Efficiency Improvements In Low-Income Homes. Energy Policy, Volume 28, Issues 6-7, June 2000, Pages 411-424

Ministry for the Environment. (2005). Warm Homes Technical Report: Home heating methods and fuels in New Zealand. Ministry for the Environment, Wellington.

Ministry of Economic Development. (2009). Electricity Prices (Real 2008 Prices).

http://www.med.govt.nz/templates/MultipageDocumentTOC_21 628.aspx (Viewed on $10 \mathrm{Feb}, 2010$ ).

Ministry of Economic Development. (2009). New Zealand Energy Data File 2009 (compiled by Hien Dang, Bryan Field, Paul Hunt, Simon Lawrence, Michael Pittams and Samuel Thornton). Energy Modelling and Statistics Unit, Energy and Resources division, Ministry of Economic Development. Prepared by: Energy Information and Modelling Group, Ministry of Economic Development. 
Ministry of Economic Development. (2010). Quarterly Survey of Domestic Electricity Prices - 15 February 2010. http://www.med.govt.nz/templates/MultipageDocumentTOC 42 774.aspx (Viewed on 20 February, 2010).

Mithraratne, N., Vale, B. and Vale, R. (2007). Sustainable Living: The Role of Whole Life Costs And Values. Butterworth-Heinemann. Amsterdam; Boston.

New Zealand Institute of Valuers. (1997). The National Modal House. New Zealand Institute of Valuers, Wellington, New Zealand.

Nielsen Media Research NZ. (2009). The Changing Home Environment 1975 2007. http://www.nztbc.co.nz/research/story.php?story=story_changing home_enviroment.inc (Viewed on 12 Dec, 2009).

NZBCSD (New Zealand Business Council for Sustainable Development). (2009). Media Release, New Survey Shows Huge Demand For Warmer Home Grants (Released on 15 September 2009). http://www.nzbcsd.org.nz/story.asp?StoryID=1024 (Viewed on 10 October, 2009).

O’Donnell, J. (2008). Energy. (LEVEL SUSTAINABILITY BUILDING SERIES) BRANZ, Judgeford, Porirua, New Zealand.

Page, I. (2008). Renovate or Demolish. BUILD issue: April/May 2008. Page 33.

Page, I. and Fung, J. (2008). Housing Typologies - Current Stock Prevalence. Report from Beacon Pathway Ltd, New Zealand.

Paula, O. (2006). The Ampere Strikes Back, How Consumer Electronics Are Taking Over The World. Produced by: Matthew Robinson, Energy Saving Trust, UK. 
PINKBATTS. (2010). Roof Insulation Products.

http://www.pinkbatts.co.nz/products/all/1/1 (Viewed on 20 Mar, 2010).

Pollard, A. (2008). Getting Energy Smart. BUILD issue: August/September 2008. pp. 53

Pollard, A. (2008). Turning Solar for Water Heating, BUILD issue:

August/September 2008. pp.58-59.

Ramos, G. and Ghisi, E. (2010). Analysis of daylight calculated using the EnergyPlus programme. Renewable and Sustainable Energy Reviews, Volume 14, Issue 7, September 2010, Pages 1948-1958).

Rawlinson \& Co. (2009). Rawlinson's New Zealand Construction Handbook, Twenty-Fourth Edition. RAWLHOUSE Publishing: Auckland.

RIGHTHOUSE. (2010). Hot Water Cylinder Wrap. http://www.righthouse.co.nz/products/insulation/hot-watercylinder (Viewed on 03 March, 2010).

Ryan, V., Burgess G., and Easton L. (2008). New Zealand House Typologies to Inform Energy Retrofits. Report from Beacon Pathway Ltd, Auckland New Zealand.

Salomon, T., and Bedel, S. (2003). The Energy Saving House. The Centre for Alternative Technology Charity Ltd., England.

Saville-Smith, K. (2008). House Owners and Energy - Retrofit, Renovation and Getting House Performance. Report from Beacon Pathway Ltd, Auckland New Zealand.

Sorrell, S. (2009). Jevons' Paradox Revisited: The Evidence for Backfire From Improved Energy Efficiency. Energy Policy Volume 37, Issue 4, April 2009, Pages 1456-1469 


\section{REFERENCES}

Standards New Zealand. (2009). NZS 4218:2009-Thermal insulation: housing and small buildings. Standards New Zealand, Wellington.

Statistics New Zealand. (2007). QuickStats About Housing-2006 Census. Revised 4 May and 27 July 2007. http://www.stats.govt.nz/Census/2006CensusHomePage/QuickStat s/quickstats-about-a-subject/housing.aspx (Viewed on 15 Dec, 2009).

Storey, J., Page, I., Wyk, L., Collins, M. and Kriel, T. (2004). Housing Interventions, Stock and Markets. Report from Beacon Pathway Ltd, Auckland, New Zealand.

Szokolay, V. (2004). Introduction to Architectural Science, The Basis of Sustainable Design. Architectural Press: Amsterdam, Boston.

Thomas, L. (2007). Alpha 134 - The Energy We Use In New Zealand Homes. Royal Society Of New Zealand.

Tims, G. (2007). House insulation guide. BRANZ, Judgeford, Porirua, New Zealand.

TVNZ, Insulation Subsidies In Hot Demand. http://tvnz.co.nz/politicsnews/minister-defends-insulation-subsidies-2991452. (Viewed on 2 Sep, 2009).

Vale, B. and Vale, R. (2001). Thermal Performance of Superinsulated Lightweight Residential Construction in the Auckland Climate. Conference paper from CIB World Building Congress, April 2001, Wellington, New Zealand.

Vale, B., and Vale, R. (2000). The New Autonomous House. Thames \& Hudson, London.

WHO (World Health Organisation). (1987). Health Impact Of Low Indoor 
Temperatures: Report On A WHO Meeting. Copenhagen, 11-14 November, 1985. WHO, Regional office for Europe, Copenhagen.

Winter, J. (2009). Retrofitting for Southern Winters. BUILD issue: April/May 2009. P38-40.

Yohanis, Y. G., Mondol, J. D., Wright, A., Norton, B. (2008). Real-life Energy Use In The UK: How Occupancy And Dwelling Characteristics Affect Domestic Electricity Use. Energy and Buildings 40, 1053-1059. 


\section{APPENDIX A: New Zealand Climate Zone}

The climate zone boundaries are based on climate data taking into consideration territorial authority boundaries, providing three zones (Standards New Zealand, 2009, p.31):

Zone 1 includes the Thames-Coromandel District, the Franklin District, and all districts north of these, and all offshore islands north of $37^{\circ} 15^{\prime}$ south.

Zone 2 includes all of North Island excluding Zone 1, the Taupo District, the

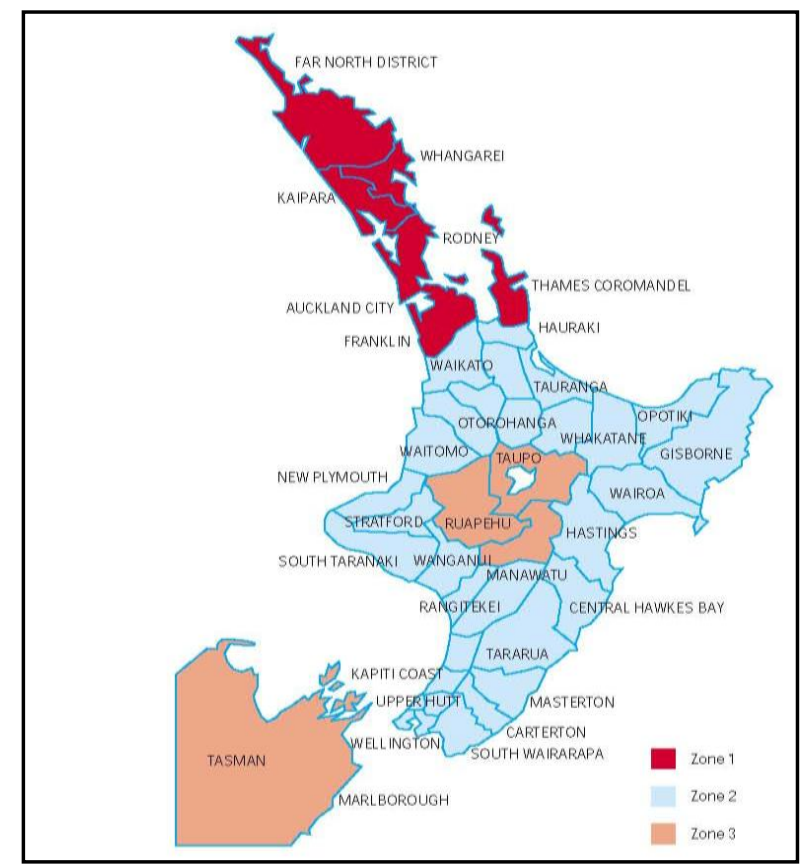
Ruapehu District, and that part of the Rangitikei District North of $39^{\circ} 50^{\prime}$ south.

Zone 3 includes the South Island, the Taupo and Ruapehu Districts, the Rangitikei District, north of $39^{\circ} 50^{\prime}$ south, and Stewart Island, the Chatham Island, and al offshore islands not in Zone 1.

Figure 24: New Zealand Climate Zones

(Source: Standards New Zealand, NZS4218:2009, p.31) 


\section{APPENDIX B: The National Modal House Plan}

The following house plan was collected from The National Modal book (New Zealand Institute of Valuers, 1997, p.6-7). Simulation study was base on this house model.

The plans are not to scale.

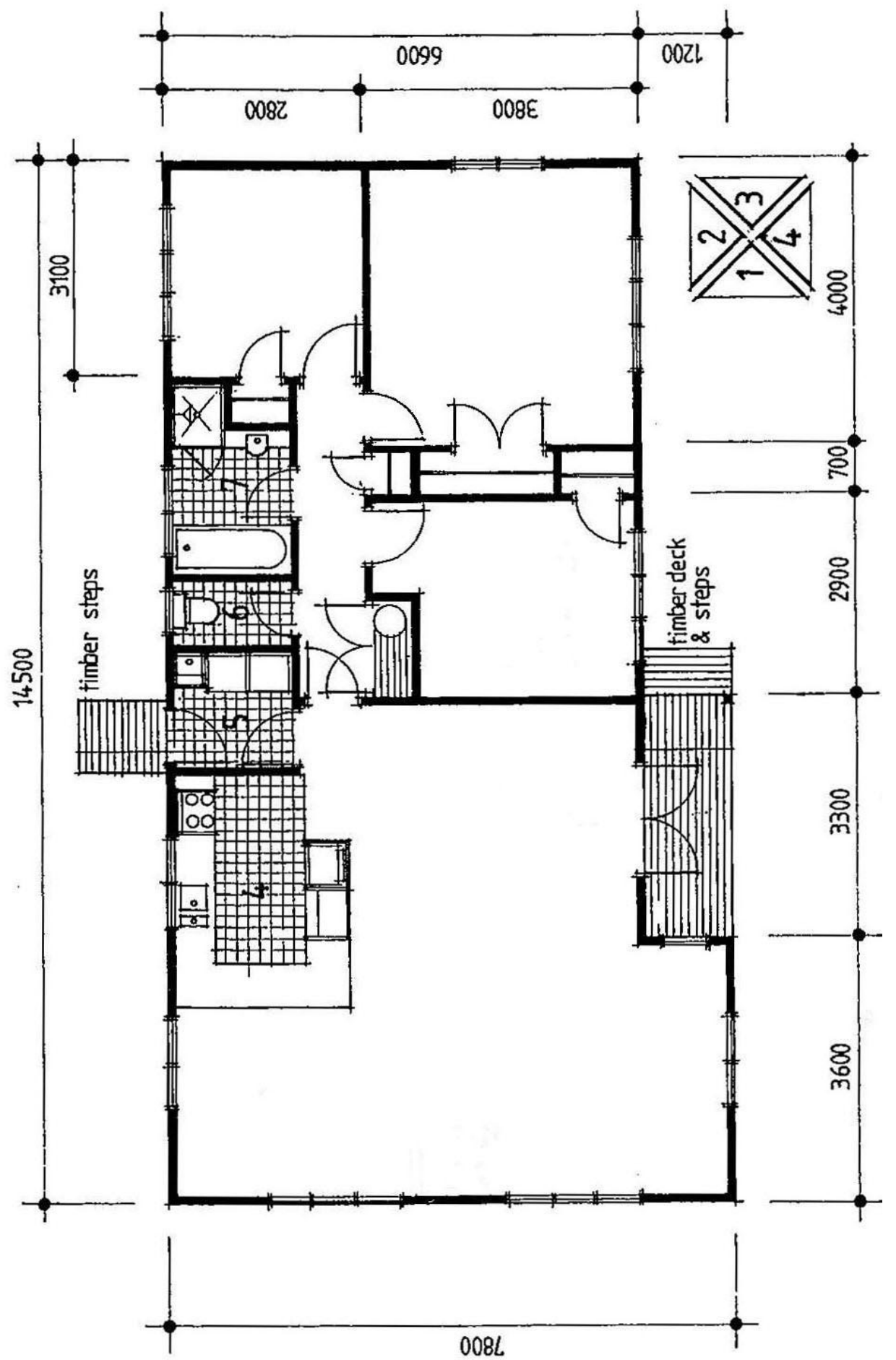

Figure 25: The National Modal House Floor Plan 


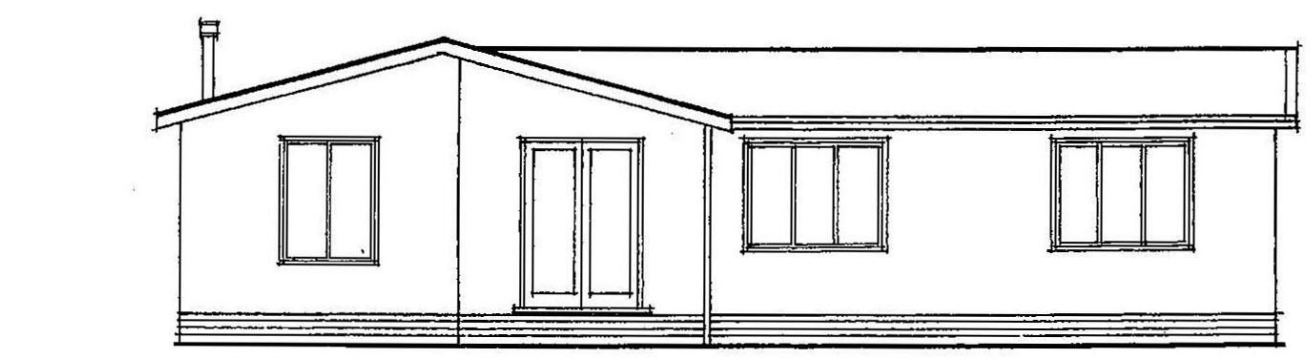

ELEVATION 4

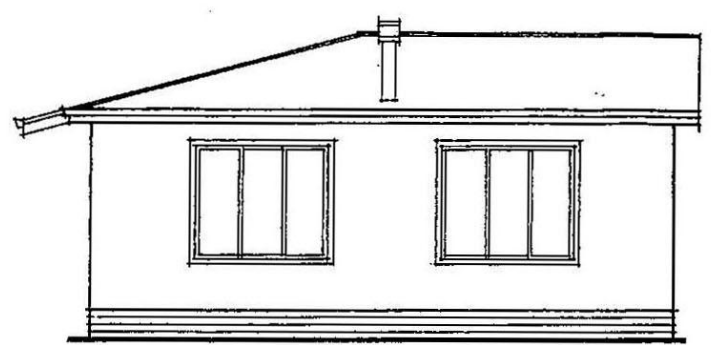

ELEVATION 1

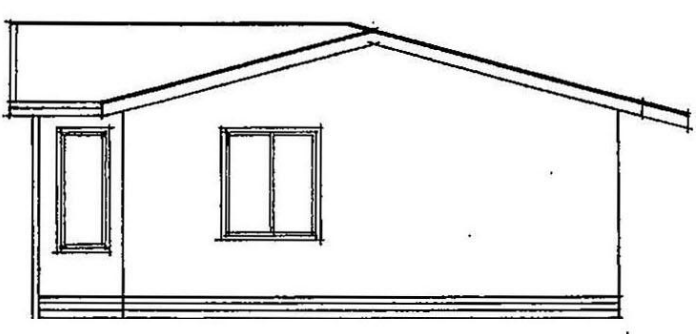

ELEVATION 3

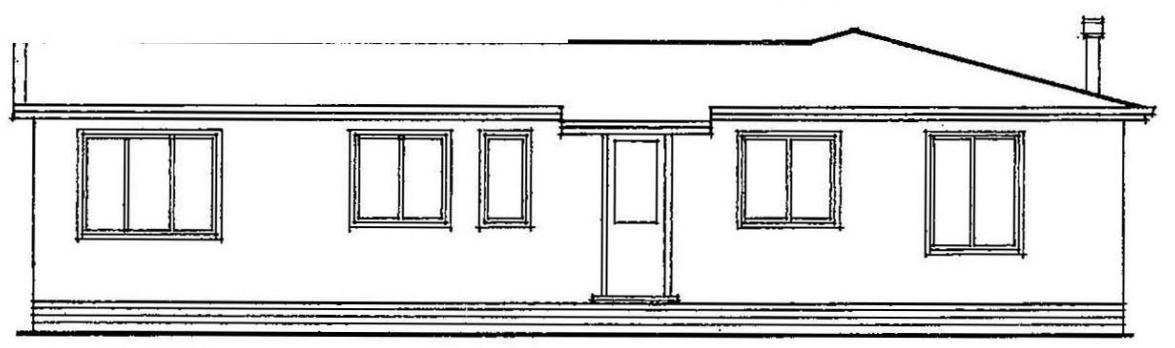

ELEVATION 2

Figure 26: The National Modal House Elevation 


\section{APPENDIX C: House Model Simulation Results}

Space heating energy requirement results from house model simulation test:

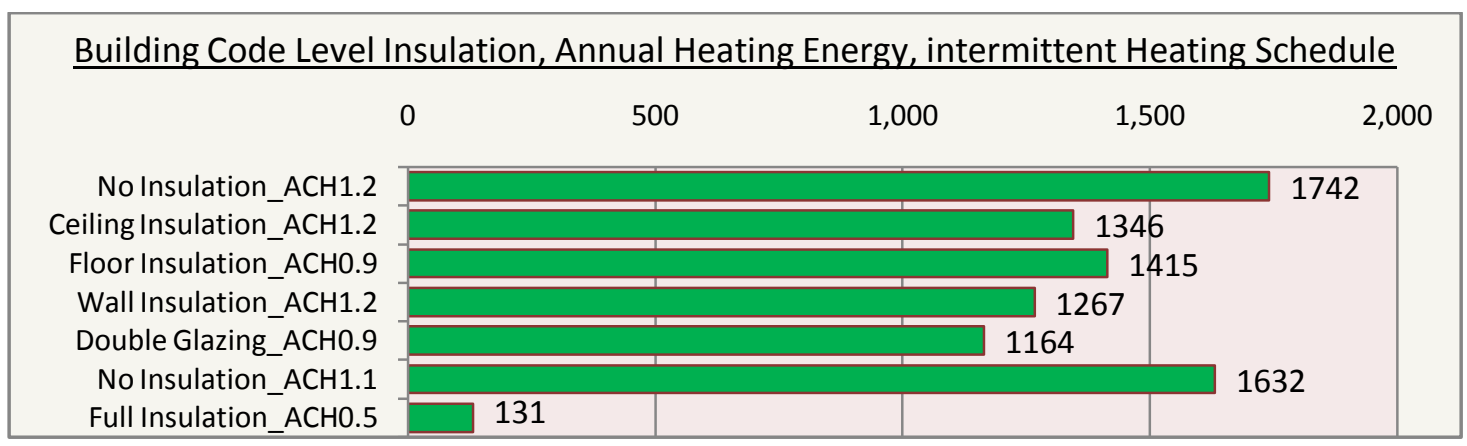

Figure 27: Building Code Level Insulation, Annual Heating Energy, Intermittent Heating Schedule

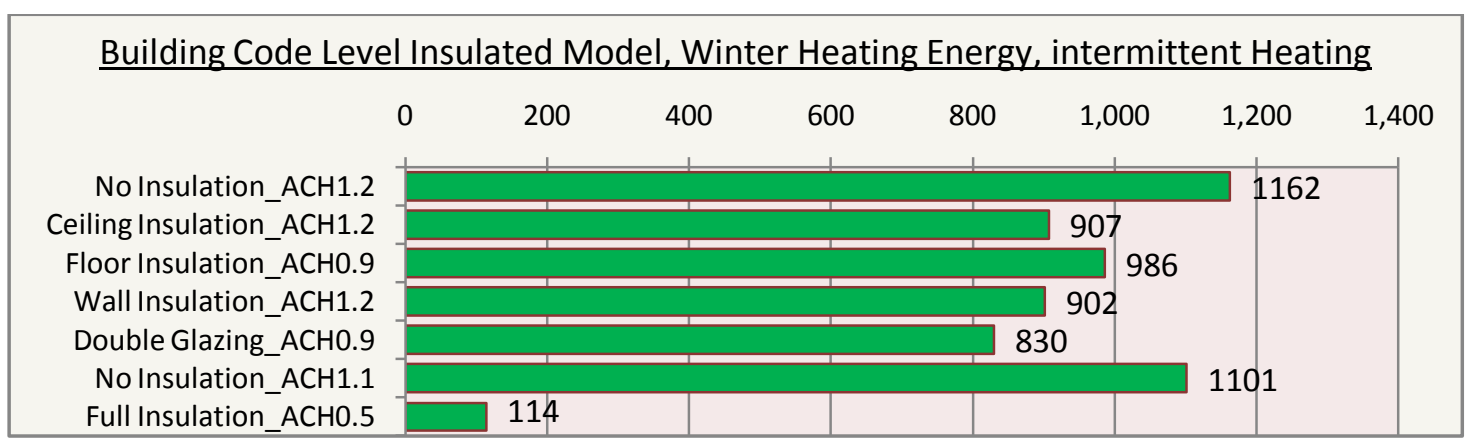

Figure 28: Building Code Level Insulation, Winter Heating Energy, Intermittent Heating Schedule

Building Code Level Insulation, Annual Heating Energy, intermittent Heating Schedule

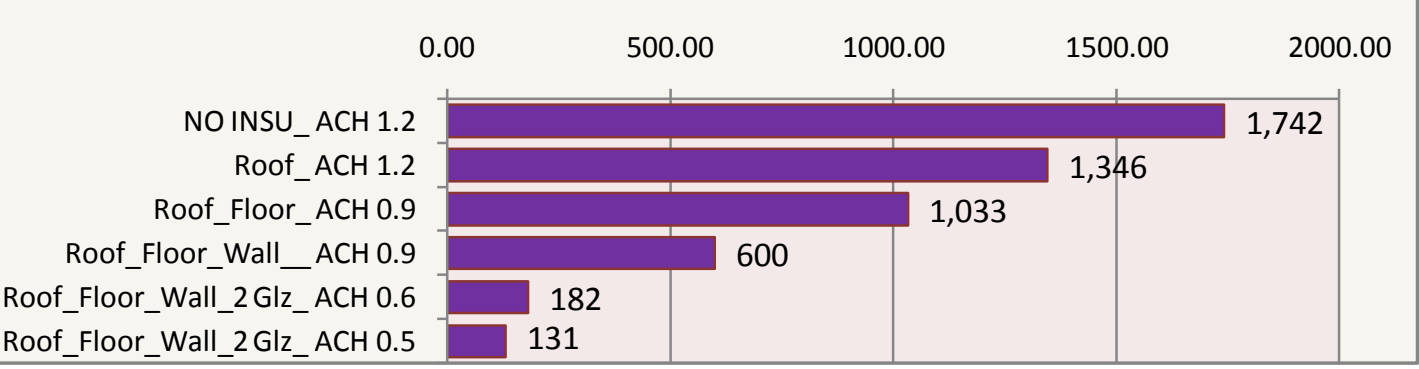

Figure 29: Building Code Level Insulation, Annual Heating Energy, Intermittent Heating Schedule

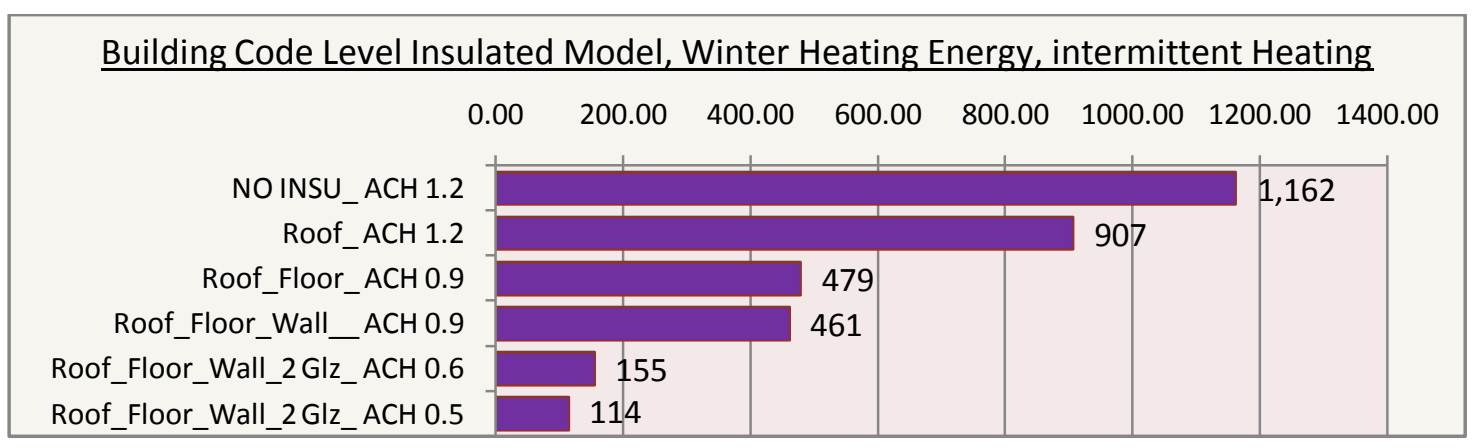

Figure 30: Building Code Level Insulation, Winter Heating Energy, Intermittent Heating Schedule 
Optimum Level Insulated Model, Annual Heating Energy, intermittent Heating Schedule

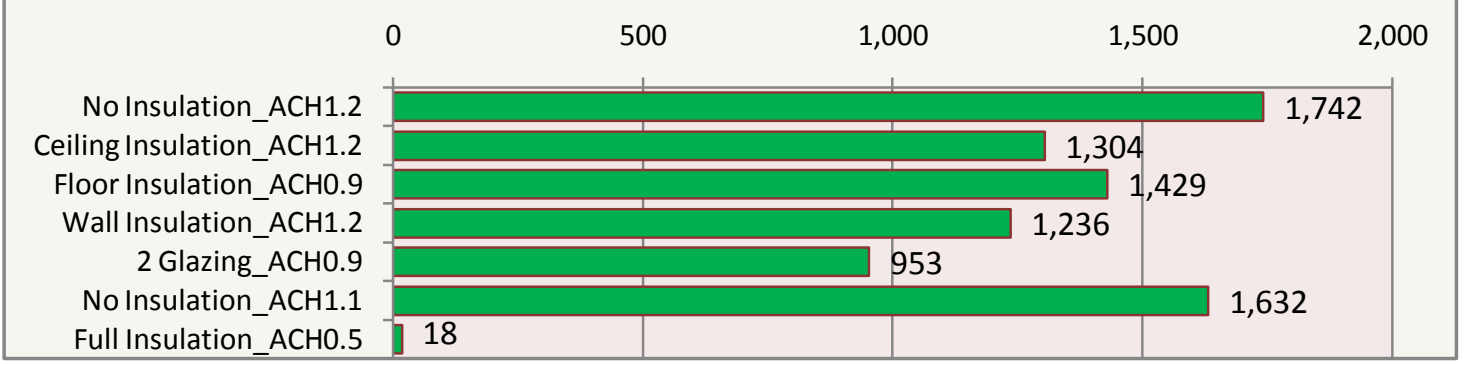

Figure 31: Optimum Level Insulation, Annual Heating Energy, Intermittent Heating Schedule

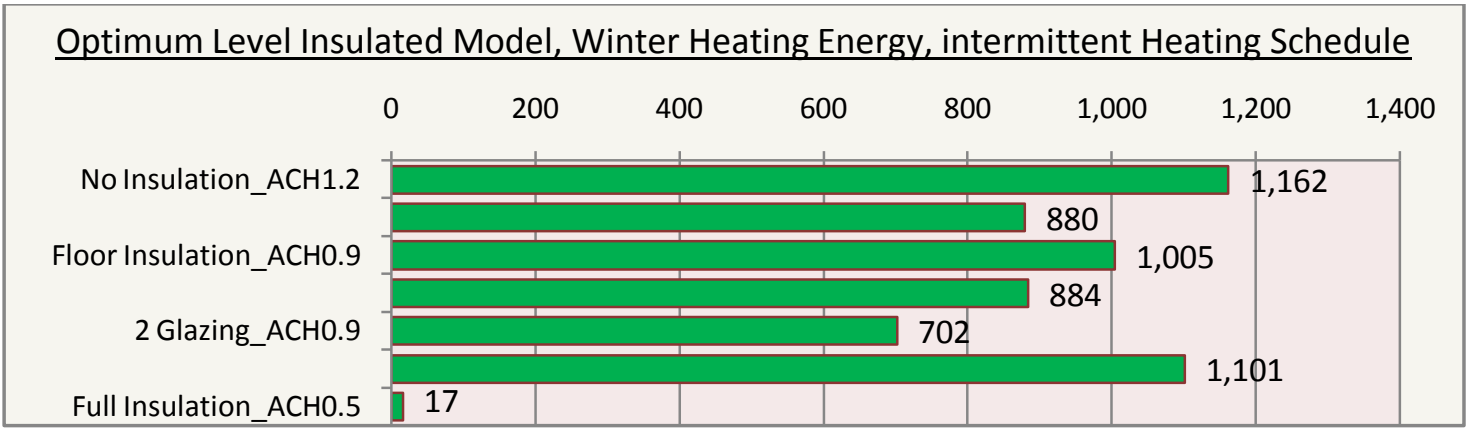

Figure 32: Optimum Level Insulation, Winter Heating Energy, Intermittent Heating Schedule

Optimum Level Insulated Model, Annual Heating Energy, intermittent Heating Schedule

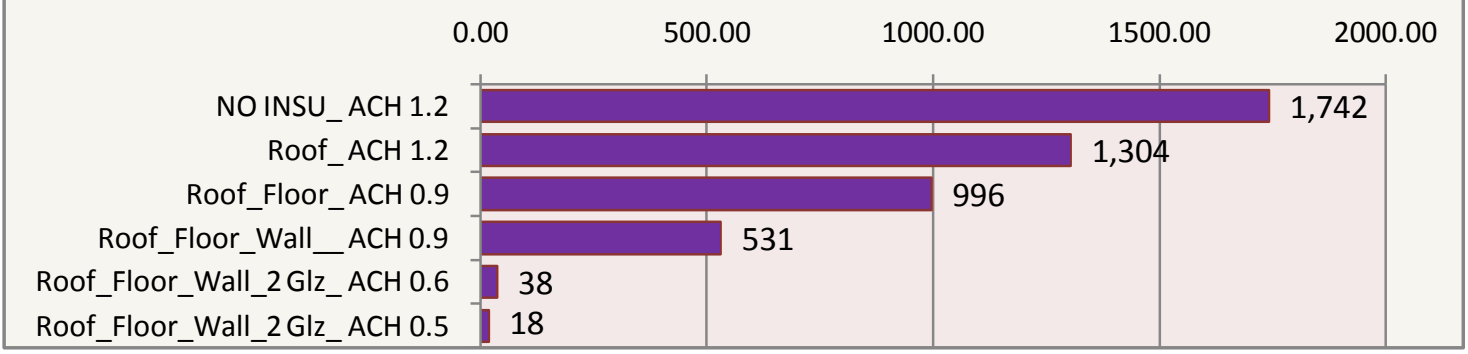

Figure 33: Optimum Level Insulation, Annual Heating Energy, Intermittent Heating Schedule

Optimum Level Insulated Model, Winter Heating Energy, intermittent Heating Schedule

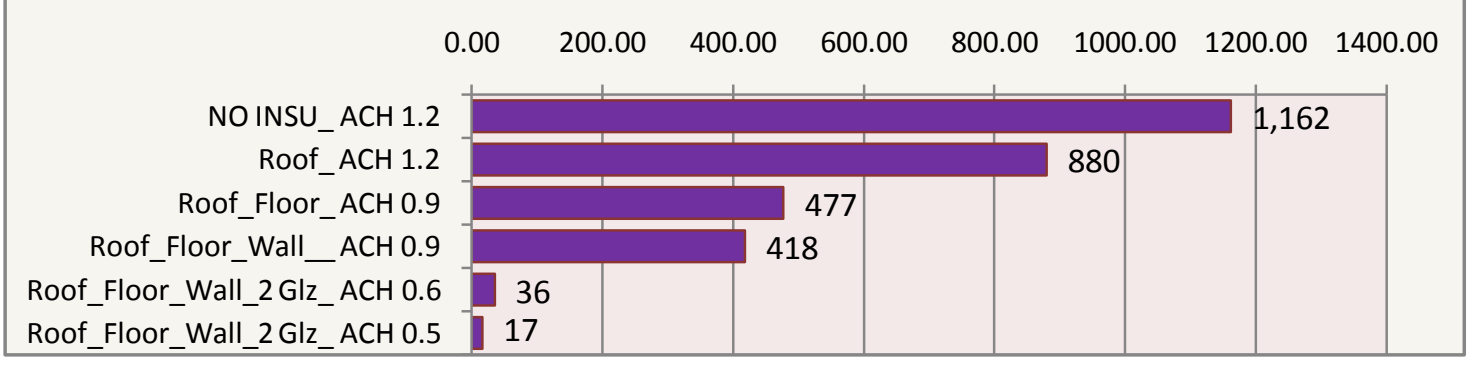

Figure 34: Optimum Level Insulation Model Winter Heating Energy, Intermittent Heating Schedule. 
Living room annual temperature simulation results:

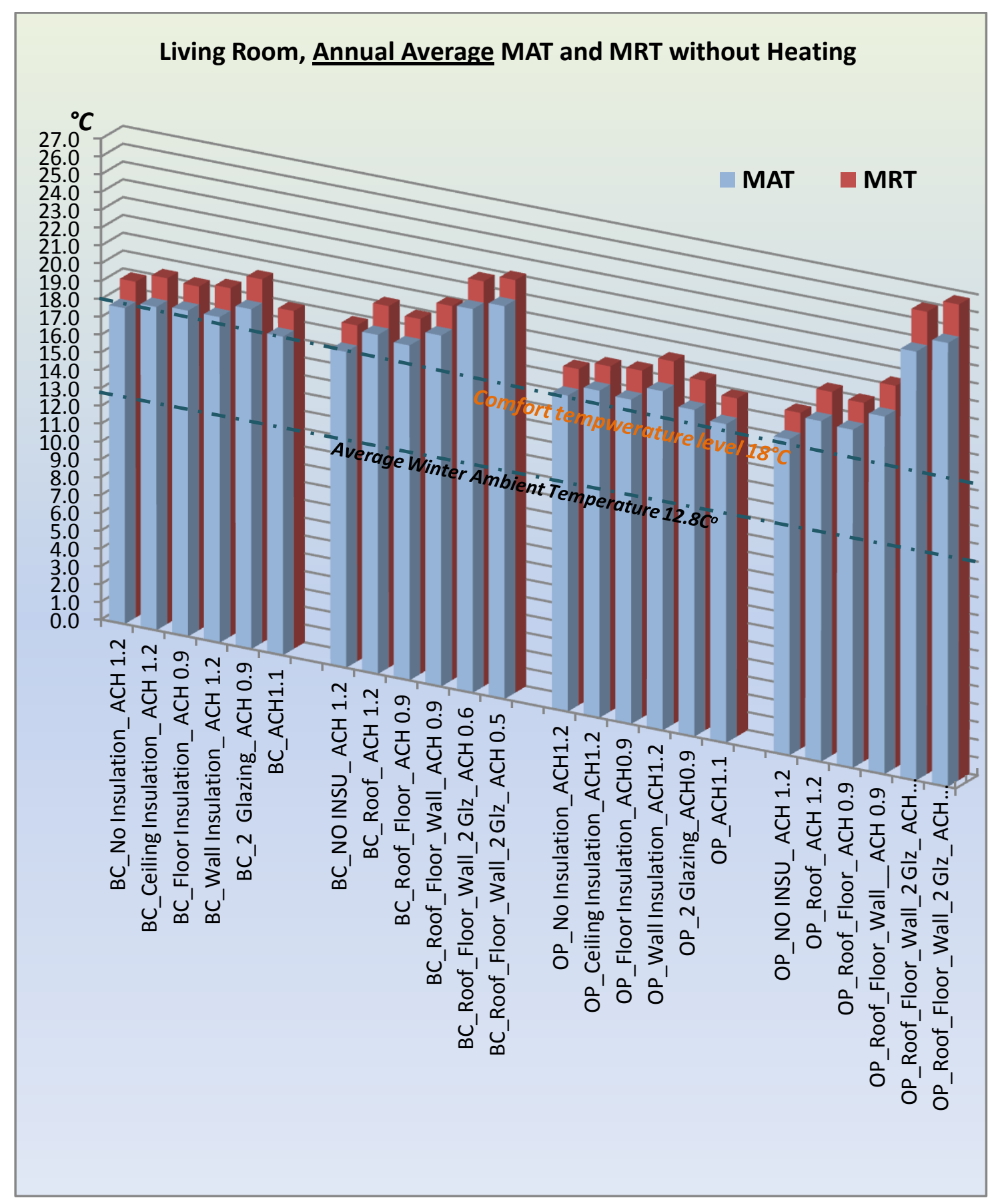

Figure 35: Living Room, Annual Average MAT and MRT without Heating 